Pogo 1 of 2 Proj.

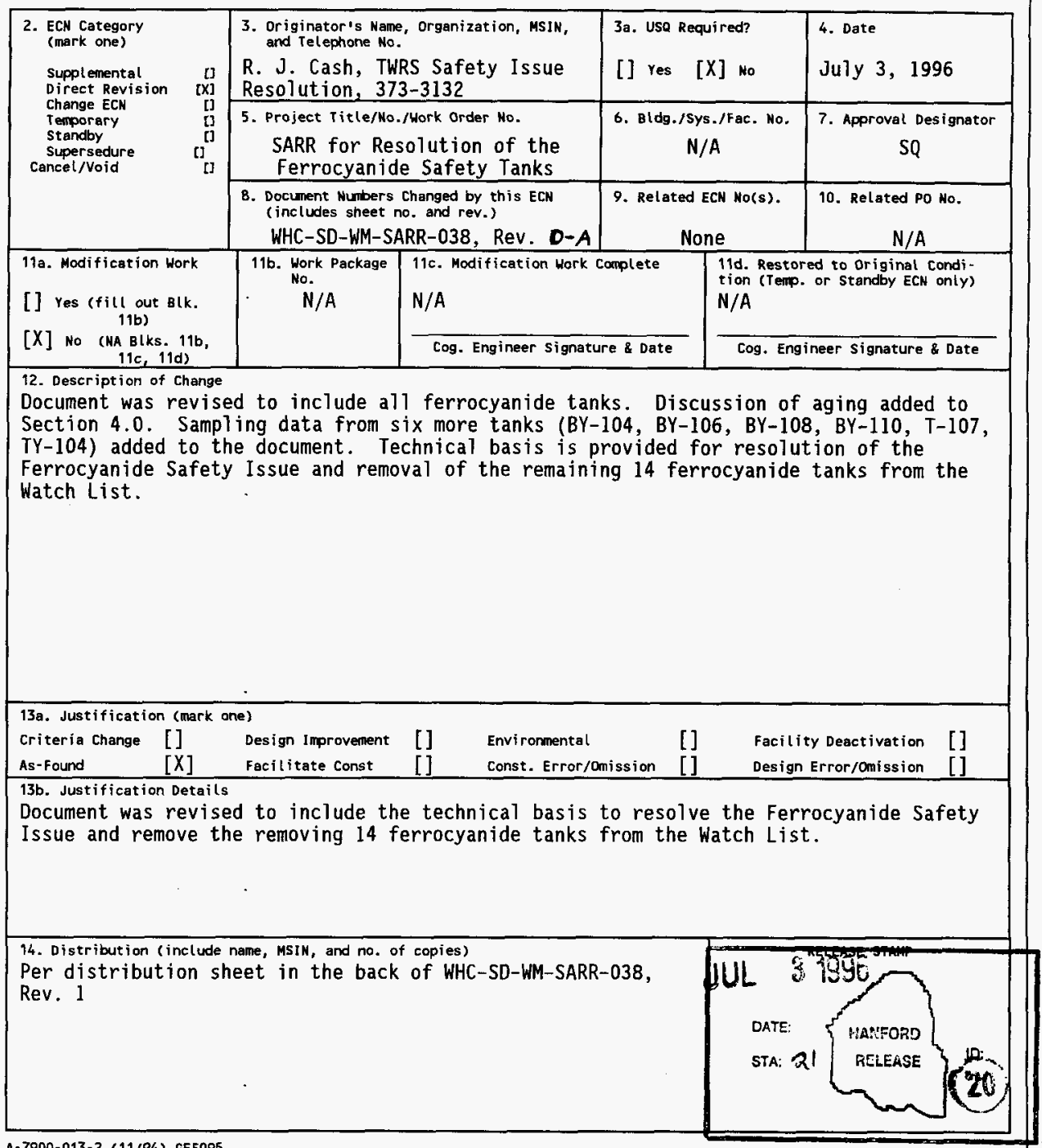




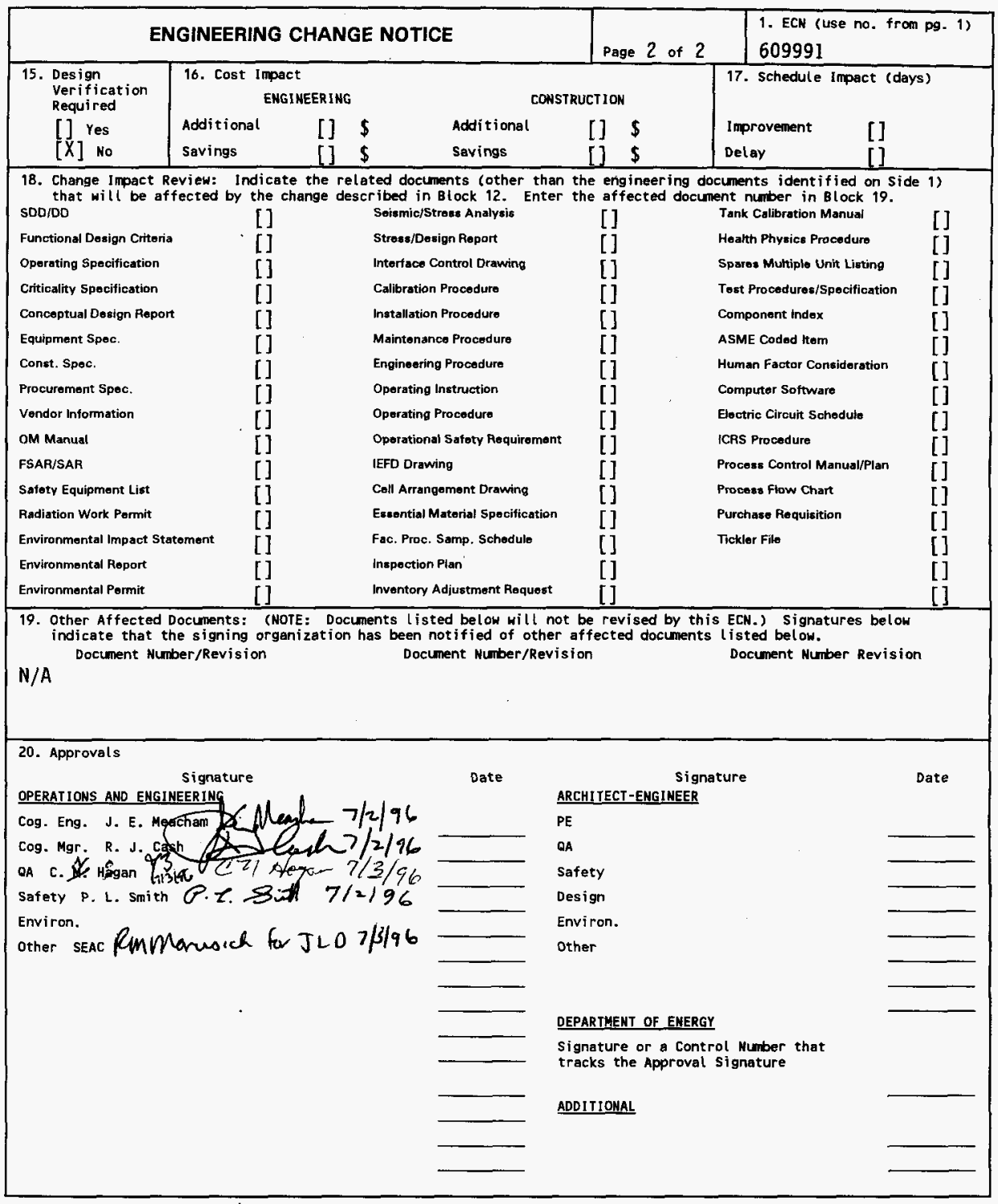




\title{
Assessment of the Potential for Ferrocyanide Propagating Reaction Accidents
}

\author{
J. E. Meacham et al. \\ Westinghouse Hanford Company, Richland, WA 99352 \\ U.S. Department of Energy Contract DE-AC06-87RL10930

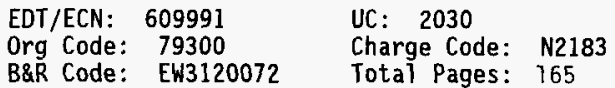

Key Words: Tank Farm Safety Analysis, Watch List, Ferrocyanide, Tank Farm Hazard Assessment, Safety Issue

Abstract: The risk posed by the continued storage of ferrocyanide wastes in Hanford Site underground storage tanks has been studied extensively using theoretical analyses, laboratory experiments, tank monitoring, and waste sampling. This report provides an assessment of this hazard and provides the technical basis to resolve the Ferrocyanide Safety Issue for the 18 tanks, and supports the removal of these tanks from the Watch List. Based on the assessment provided in this report, the ferrocyanide waste in all 18 of the current ferrocyanide Watch List tanks, is categorized as safe and cannot burn or explode.

TRADEMARK DISCLAIMER. Reference herein to any specific comercial product, process, or service by trade name, tradenark, manufacturer, or otherwise, does not necessarily constitute or imply its endorsenent, recommendation, or favoring by the United States Government or any agency thereof or its contractors or subcontractors.

Printed in the United States of America. To obtain copies of this document, contact: WHC/BCS pocument Control Services, P.0. Box 1970, Mailstop H6-08, Richland UA 99352, Phone (509) 372-2420; Fax (509) 376-4989.
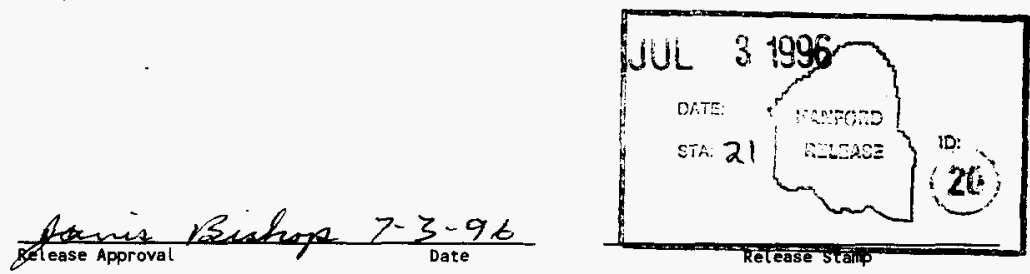

Approved for Public Release 


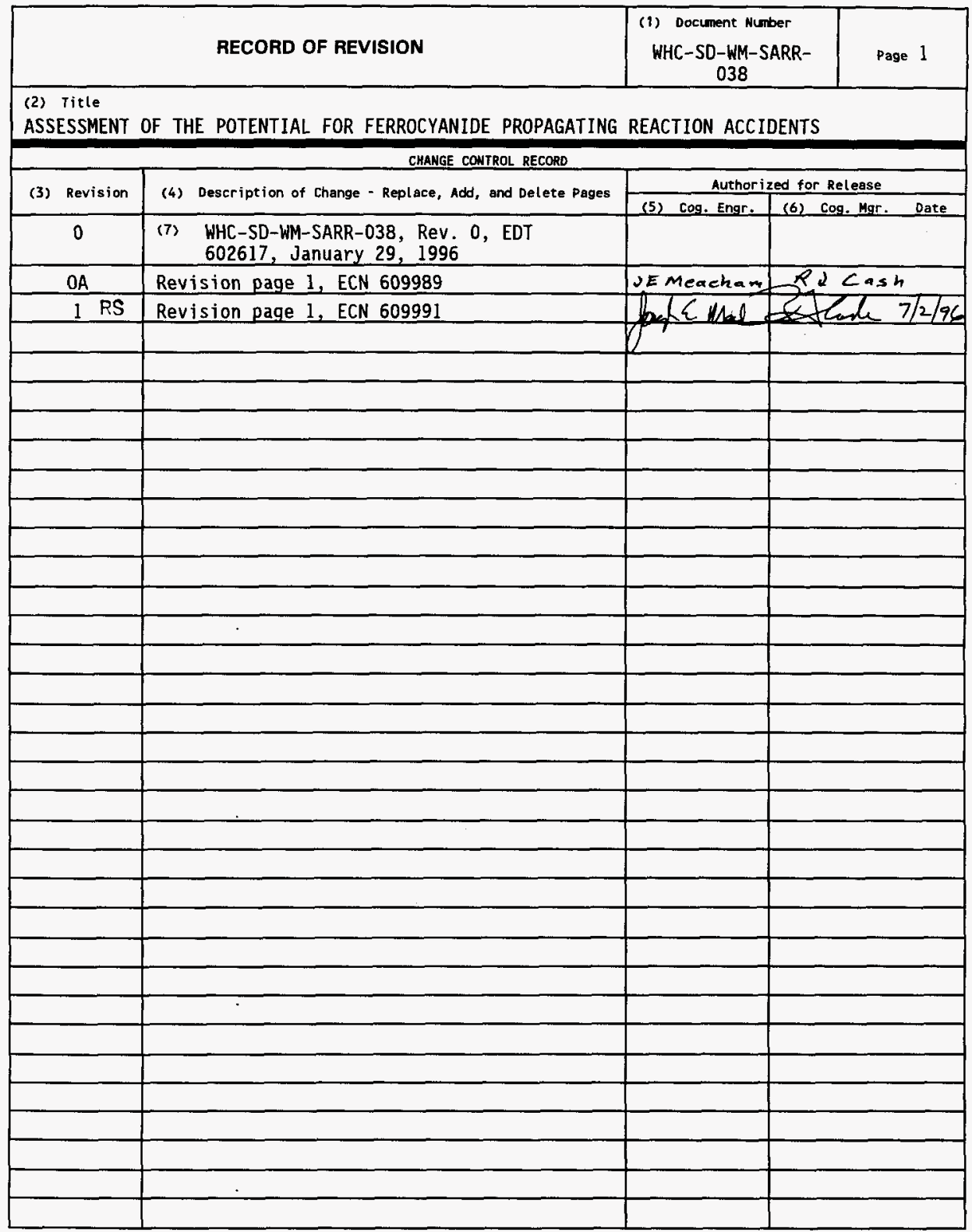




\title{
Assessment of the Potential for Ferrocyanide Propagating Reaction Accidents
}

\author{
J. E. Meacham \\ R. J. Cash \\ D. R. Dickinson \\ F. R. Reich \\ Westinghouse Hanford Company \\ J. M. Grigsby \\ A. K. Postma \\ G\&P Consulting, Inc. \\ M. A. Lilga \\ Pacific Northwest National Laboratory \\ Date Published \\ July 1996
}

Prepared for the U.S. Department of Energy

Assistant Secretary for Environmental Management

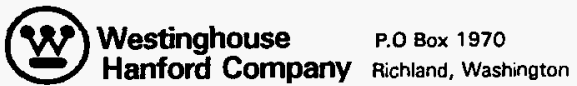

Manegement and Operations Contractor for the

U.S. Depertment of Energy under Contrect DE-ACO6-87RL 10930

Approved for public release; distribution is unlimited 


\section{ASSESSMENT OF THE POTENTIAL FOR FERROCYANIDE PROPAGATING REACTION ACCIDENTS}

\section{EXECUTIVE SUMMARY}

Defense waste operations at the Hanford Site during the 1950 s used ferrocyanide, in a number of waste tanks, to scavenge ${ }^{137} \mathrm{Cs}$ from waste supernates. This formed ferrocyanide-containing sludges that settled in layers in a number of waste tanks. As a result of these operations, approximately 140 metric tons of ferrocyanide [as $\left.\mathrm{Fe}(\mathrm{CN})_{6}^{-4}\right]$ were added to 18 single-shell tanks at the Hanford Site. Ferrocyanide, in sufficiently high concentrations and mixed with oxidizing material such as sodium nitrate/nitrate, can react exothermically or even explode when heated to high temperatures.

The risk posed by the continued storage of ferrocyanide wastes in Hanford Site underground storage tanks has been studied extensively. Waste sample data coupled with laboratory experiments show that the ferrocyanide has decomposed (aged) to inert chemicals through radiolysis and hydrolysis. All of the ferrocyanide waste has aged and the waste cannot combust or explode. Based on the assessment provided in this report, all eighteen ferrocyanide tanks are categorized as safe, and the tanks should be removed from the Watch List. 
WHC-SD-WM-SARR-038, Rev. 1

This page intentionally left blank. 


\section{TABLE OF CONTENTS}

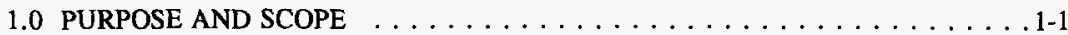

2.0 BACKGROUND . . . . . . . . . . . . . . . . . . . 2-1

2.1 UNREVIEWED SAFETY QUESTION $\ldots \ldots \ldots \ldots \ldots \ldots \ldots \ldots \ldots .2-1$

2.2 WATCH LIST $\ldots \ldots \ldots \ldots \ldots \ldots \ldots \ldots \ldots \ldots \ldots \ldots \ldots \ldots \ldots \ldots \ldots \ldots \ldots \ldots .2-2$

2.3 DNFSB RECOMMENDATION $90-7 \ldots \ldots \ldots \ldots . . \ldots \ldots . . .24$

2.4 APPROACH TO RESOLUTION OF THE FERROCYANIDE SAFETY

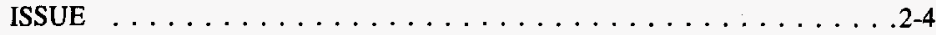

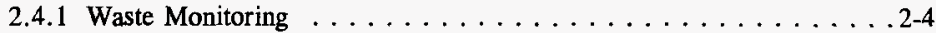

2.4.2 Ferrocyanide Chemical Properties . . . . . . . . . 2-5

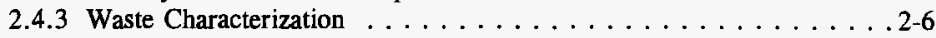

3.0 HAZARD POTENTIAL AND POSTULATED FERROCYANIDE ACCIDENTS . . 3-1

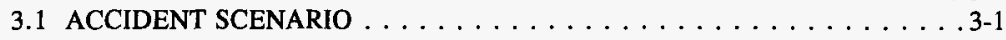

3.2 FERROCYANIDE SAFETY CRITERIA $\ldots \ldots \ldots \ldots \ldots \ldots \ldots \ldots$ 3-4

3.2 .1 Theoretical Analysis . . . . . . . . . . . . . . . . 3-4

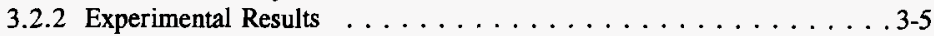

3.3 WASTE SAFETY CATEGORIES $\ldots \ldots \ldots \ldots \ldots \ldots \ldots \ldots \ldots \ldots$

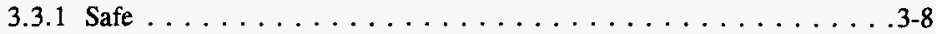

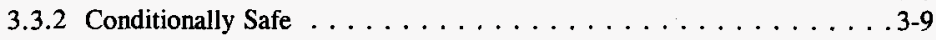

3.3.3 Unsafe $\ldots \ldots \ldots \ldots \ldots \ldots \ldots \ldots \ldots \ldots \ldots \ldots \ldots . . . \ldots \ldots$

4.0 ASSESSMENT OF FERROCYANIDE WASTE CONDITIONS . . . . . . . . 4-1

4.1 HISTORICAL RECORDS $\ldots \ldots \ldots \ldots \ldots \ldots \ldots \ldots \ldots \ldots \ldots \ldots \ldots \ldots$

4.2 FERROCYANIDE AGING $\ldots \ldots \ldots \ldots \ldots \ldots \ldots \ldots .1$

4.2.1 Parameters Affecting the Rate of Aging . . . . . . . . . 4-3

4.2.2 Tank Waste Temperature Histories . . . . . . . . . . . 4-5

4.2.3 Confirmation of Ferrocyanide Aging from Waste Sample Data . . . 4-7

4.2.4 Ferrocyanide Aging Estimates for Unsampled Watch List Tanks . . . 4-8

4.2.5 Conclusion on Ferrocyanide Waste Aging . . . . . . . . . . 4-9

5.0 WASTE HAZARD POTENTIAL AND ACCIDENT FREQUENCY $\ldots \ldots \ldots$ 5-1

5.1 TANKS CONTAINING IN FARM SLUDGE $\ldots \ldots \ldots \ldots \ldots \ldots \ldots .5-2$

5.2 TANKS CONTAINING U PLANT SLUDGE $\ldots \ldots \ldots \ldots \ldots \ldots \ldots$

5.3 TANKS CONTAINING T PLANT SLUDGE $\ldots \ldots \ldots \ldots \ldots \ldots$. $\ldots \ldots$

5.4 HAZARD POTENTIAL AND ACCIDENT FREQUENCY

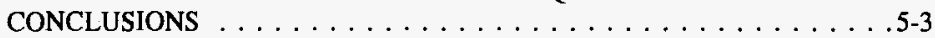

6.0 SAFETY CONCLUSIONS AND REQUIRED CONTROLS $\ldots \ldots \ldots \ldots$. . . . .

7.0 REFERENCES . . . . . . . . . . . . . . . . . . . 
WHC-SD-WM-SARR-038, Rev. 1

TABLE OF CONTENTS (Continued)

APPENDIXES

A STATISTICAL ANALYSIS OF FERROCYANIDE AND NICKEL CONCENTRATIONS IN SAMPLED WASTE TANKS $\ldots \ldots \ldots \ldots \ldots \ldots$ A-1

B STATISTICAL ANALYSIS OF FERROCYANIDE AND NICKEL CONCENTRATIONS IN SAMPLED WASTE TANKS - WEIBULL MODEL . . B-1

C PROCESS AND TEMPERATURE HISTORIES FOR THE FERROCYANIDE WATCH LIST TANKS $\ldots \ldots \ldots \ldots \ldots \ldots \ldots \ldots \ldots \ldots \ldots . \ldots . . \ldots \ldots$

D FERROCYANIDE AGING EXPERIMENTS $\ldots \ldots \ldots \ldots \ldots \ldots$ D-1 


\section{LIST OF FIGURES}

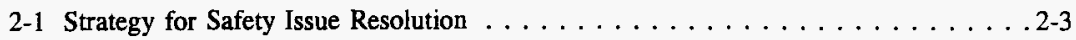

3-1 Ferrocyanide Reaction Accident Event Tree $\ldots \ldots \ldots \ldots \ldots \ldots$. . . . . . . .

4-1 Rate Constants (k) versus Temperature at Various Gamma Dose Rates . . . . . . . 4-4

\section{LIST OF TABLES}

3-1 Summary of RSST Tests Regarding Propagation $\ldots \ldots \ldots \ldots \ldots \ldots$ 3-6

3-2 Summary of Ferrocyanide Tube Propagation Tests $\ldots \ldots \ldots \ldots \ldots$ 3-8

4-1 Estimated Original Ferrocyanide $\ldots \ldots \ldots \ldots \ldots \ldots \ldots \ldots \ldots \ldots \ldots \ldots \ldots \ldots \ldots .2$

4-2 Aging Rates as a Function of Temperature for Waste Simulant Experiments. . . . . 4-4

4-3 Sample Data Confirming Ferrocyanide Aging $\ldots \ldots \ldots \ldots \ldots \ldots$ 4-8

4-4 Estimated Current Ferrocyanide Concentrations in the Unsampled Tanks. . . . . . 4-9

\section{MEASUREMENTS}

Tank temperature, depth and volume measurements in Appendixes A, B and C were obtained in English units and are given without SI conversions. 


\section{LIST OF TERMS}

$\begin{array}{ll}\gamma & \text { gamma } \\ \Delta \mathrm{H} & \text { calculated energy } \\ \text { cm } & \text { centimeters } \\ \text { DNFSB } & \text { Defense Nuclear Facilities Safety Board } \\ \text { DOE } & \text { U.S. Department of Energy } \\ \text { EMI } & \text { electromagnetic induction } \\ \text { g } & \text { grams } \\ \text { Gy/s } & \text { grays per second } \\ \text { HTCE } & \text { historical tank content estimate } \\ \text { ITS } & \text { in-tank solidification } \\ \text { kcal } & \text { kilocalories } \\ \text { kg } & \text { kilogram } \\ \text { L } & \text { liters } \\ \text { lb } & \text { pounds } \\ M & \text { molar } \\ \text { MJ } & \text { megajoules } \\ \text { mol/L } & \text { moles per liter } \\ \text { NIR } & \text { near-infrared spectroscopy } \\ \text { Rad/h } & \text { rads per hour } \\ \text { RSST } & \text { reactive system screening tool (a small adiabatic calorimeter) } \\ \text { SST } & \text { single-shell tank } \\ \text { UR } & \text { uranium recovery } \\ \text { USQ } & \text { unreviewed safety question } \\ \text { W } & \text { watts } \\ \text { W/kg } & \text { watts per kilogram } \\ \text { W/m } & \text { watts per cubic meter } \\ \text { wt } \% & \text { weight percent } \\ & \\ & \end{array}$




\section{LIST OF DEFINITIONS}

Aging. As used in this report, aging means chemical and radiolytic degradation (also termed radiochemical degradation) that reduces the ferrocyanide (fuel) concentration in ferrocyanide-bearing materials.

Bound water content. Bound water in waste is water remaining in waste after free water is removed. Bound water has been measured at 4.6 molecules of $\mathrm{H}_{2} \mathrm{O}$ per molecule of sodium nickel ferrocyanide $\left[\mathrm{Na}_{2} \mathrm{NiFe}(\mathrm{CN})_{6}\right]$ on the basis of tests described in Postma et al. (1994).

Free water content. Free water is water in ferrocyanide waste that can be removed from samples by drying in a laboratory oven at $105^{\circ} \mathrm{C}\left(221^{\circ} \mathrm{F}\right)$ for 24 hours. As an example, if a 10-gram sample of waste lost five grams of water after drying, the free water content of the waste would be assigned a value of $50 \mathrm{wt} \%$.

Total water content. Total water content is the sum of the free and bound water contents.

Sodium nickel ferrocyanide on a dry-weight basis. This is the sodium nickel ferrocyanide $\left[\mathrm{Na}_{2} \mathrm{NiFe}(\mathrm{CN})_{6}\right]$ content after drying using standard drying methods. The bound water would still be present and included in the compound on a weight basis.

Dry sodium nickel ferrocyanide. Dry sodium nickel ferrocyanide $\left[\mathrm{Na}_{2} \mathrm{NiFe}(\mathrm{CN})_{6}\right]$ is the ferrocyanide compound alone, with no bound water.

Ferrocyanide concentration on an energy equivalent basis. Theoretical analyses described herein indicate that the criterion for reaction propagation is closely related to exothermic reaction energy per unit mass of waste. The energy equivalent concentration of ferrocyanide is a value computed from a measured exotherm in a waste sample using a specific reaction energy of 6 megajoules per kilogram $(\mathrm{MJ} / \mathrm{kg})$ for pure sodium nickel ferrocyanide. For example, if a waste sample exhibited a reaction exotherm of $0.6 \mathrm{MJ} / \mathrm{kg}$ of waste on a zero free water basis, the energy equivalent ferrocyanide concentration would be calculated as:

$$
\frac{0.6 \mathrm{MJ}}{\mathrm{kg} \text { waste }} \times \frac{1 \mathrm{~kg} \mathrm{Na} \mathrm{NiFe}_{(\mathrm{CN})_{6}}}{6 \mathrm{MJ}} \times 100=10 \% \mathrm{Na}_{2} \mathrm{NiFe}(\mathrm{CN})_{6}
$$

on a zero free water basis. The technical basis for this definition of ferrocyanide concentration on an energy equivalent basis is described in Postma et al. (1994). 
WHC-SD-WM-SARR-038, Rev. 1

This page intentionally left blank. 


\subsection{PURPOSE AND SCOPE}

The potential for sustained rapid exothermic reactions involving ferrocyanide in Hanford Site waste is discussed in this topical report. More specifically, a technical basis is provided for resolving the Ferrocyanide Safety Issue and for removal of all eighteen ferrocyanide tanks (241-BY-103, BY-104, BY-105, BY-106, BY-107, BY-108, BY-110, BY-111, BY-112, C-108, C-109, C-111, C-112, T-107, TX-118, TY-101, TY-103, and TY-104) from the Wyden Amendment Watch List (Public Law 101-510, 1990).

The technical basis for removing the four C Farm tanks (241-C-108, C-109, C-111, and $\mathrm{C}-112$ ) was provided in Revisions 0 and OA (Grigsby et al. 1996) of this document; it is included in this document for completeness. These four tanks were removed from the Watch List by the U.S. Department of Energy (DOE) in June 1996 (Kinzer 1996).

The scope of this report is limited to only the hazard posed by ferrocyanide sludges and does not address other hazards that may be associated with these tanks, such as organic-nitrate condensed-phase reactions or flammable gas deflagrations. 
WHC-SD-WM-SARR-038, Rev. 1

This page intentionally left blank. 


\subsection{BACKGROUND}

Radioactive waste from defense operations has accumulated in the Hanford Site's waste storage tanks since the early 1940s. During the 1950 s, additional tank storage space was required to support the defense mission. To obtain this additional storage space quickly, while minimizing the need to construct additional storage tanks, Hanford Site scientists developed processes to concentrate wastes by removing liquids from the stored wastes. The processes removed (scavenged) radiocesium and other soluble radionuclides from tank waste liquids via precipitation. After the radionuclide concentrations in the supernatant were reduced below established limits, the liquid was decanted to cribs and trenches. The solids that precipitated in the tank contained ferrocyanide, and these solids accumulated in various settling tanks as a waste sludge. Some of the settled sludges were transferred to accumulation tanks for storage. Approximately 140 metric tons (154 tons) of ferrocyanide [as $\left.\mathrm{Fe}(\mathrm{CN})_{6}^{-4}\right]$ were used during the scavenging campaign.

In the presence of oxidizing material such as sodium nitrate and/or nitrite, ferrocyanide can be made to react exothermically and undergo a propagating combustion by heating it to high temperatures or by applying an electrical spark of sufficient energy (Cady 1993). Because the scavenging process precipitated ferrocyanide from solutions containing nitrate and nitrite, there was a concern that intimate mixtures of ferrocyanides and nitrates/nitrites existed in some regions of the ferrocyanide tanks.

The Ferrocyanide Safety Issue was a result of a combination of factors, beginning with the safety studies performed as precursors to using the ferrocyanide scavenging flowsheets in the 1950s. These studies did not address long-term storage of the ferrocyanide solids nor were they performed to the conservative standards used today. Before 1990, safety studies determining the risk of adding other chemicals were either not performed or were performed to less conservative standards. Monitoring systems, such as temperature measurement instrumentation, were allowed to be disconnected and fall into disrepair because the potential risk was not highlighted. A formal program was started in September 1990 to resolve the Ferrocyanide Safety Issue (Cash 1991).

The approach to resolution of the Ferrocyanide Safety Issue was influenced by the need to fulfill three specific tasks discussed below: 1) close the ferrocyanide Unreviewed Safety Question (USQ); 2) complete actions required to meet Defense Nuclear Facilities Safety Board (DNFSB) Recommendation 90-7; and 3) complete actions required by the Wyden Amendment (Public Law 101-510, Section 3137). The following sections provide background information on these issues, and review how the approach to resolution has evolved since 1990.

\subsection{UNREVIEWED SAFETY QUESTION}

Originally, little was known about the potential hazards of a ferrocyanide-nitrate/nitrite reaction in Hanford Site single-shell tanks (SSTs). Because the safety envelope was not 
adequately defined by the existing analyses, an inadequacy existed in the authorization basis. Specifically, the existing safety analysis report (Smith 1986) and subsequent analyses such as the 1987 environmental impact statement (DOE 1987) did not adequately define the conditions necessary to preclude propagating reactions in the ferrocyanide waste; therefore, a USQ was declared on October 12, 1990 (Deaton 1990).

A strategy for closing the USQ and resolving the Ferrocyanide Safety Issue was developed by the U.S. Department of Energy (DOE) and Westinghouse Hanford Company and presented to the Defense Nuclear Facility Safety Board (DNFSB) in August 1993 (Grumbly 1993). The strategy (see Figure 2-1) uncoupled USQ closure from final resolution of the Ferrocyanide Safety Issue. The strategy contained two key steps: 1) development of criteria for three safety categories that rank the hazard for each tank (safe, conditionally safe, and unsafe) and hence allow closure of the USQ (see Section 3.3); and 2) confirmation and final placement of each tank into one of the categories based on core sampling and analyses of the tank contents.

Based on the knowledge gained from simulant studies, theoretical analyses, and analyses of actual waste samples, safety criteria were defined for the ferrocyanide waste (Postma et al. 1994). These criteria were reviewed and accepted by external oversight panels and the DOE. The USQ was closed in March 1994 by the DOE Assistant Secretary for Environmental Restoration and Waste Management (Sheridan 1994a).

\subsection{WATCH LIST}

In March 1989 (Nguyen 1989), based on process knowledge, process records, transfer records, and $\log$ books, 22 Hanford Site tanks were originally identified as containing 1,000 gram-moles (g-moles) ${ }^{1}(211 \mathrm{~kg}[465 \mathrm{lb}])$ or more of ferrocyanide [as the $\mathrm{Fe}(\mathrm{CN})_{6}^{-4}$ anion]. Two additional ferrocyanide tanks were identified in January 1991 (Borsheim and Cash 1991), increasing the number of ferrocyanide tanks to 24 . To avert possible injury to personnel and damage to the facility or environment, strict controls were identified for these and other safety issue tanks in Operating Specifications for Watch List Tanks (WHC 1990). Tanks identified by this document (see WHC 1996 for the latest revision) have been commonly referred to as Watch List tanks.

In November 1990, the Wyden Amendment (Public Law 101-510, Section 3137 [1990]) was enacted. This law required the identification of Hanford Site tanks that may have a serious potential for release of high-level waste. The tanks identified in Operating Specifications for Watch List Tanks (WHC 1990) provided the basis for the list in the February 1991 report to Congress (Watkins 1991) that responded to the Wyden Amendment.

\footnotetext{
${ }^{1}$ The $1,000 \mathrm{~g}$-moles criterion has since been replaced with a 480 Joules per gram (115 calories per gram) fuel concentration criterion (Meacham et al. 1995a).
} 


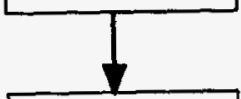

Statement of Concem

- Criteria for Safety Issue Resolution developed and classified into three levels (safe, conditionally safe, and unsafo)

- Theoretical analyses and waste simulant studies demonstrate adequacy of criteria

\section{- Documentation per} DOE 5480.21

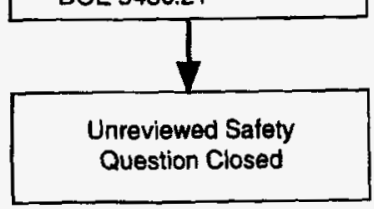

- Representative Tank Wastes Samples to confirm that criteria are met

- Necessary monitoring. controls, and procedures are in place to ensure operations are conducted within criteria

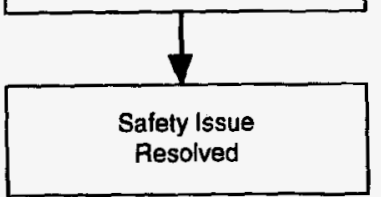


The 24 ferrocyanide tanks were among the tanks identified and included on the list. However, a re-examination of the historical records (Borsheim and Simpson 1991) indicated that six of the 24 tanks did not contain the requisite $1,000 \mathrm{~g}$-moles of ferrocyanide and should not have been included on the Watch List nor identified in the response to the Wyden Amendment. Four of these six tanks were removed from the Watch List in July 1993 (Anttonen 1993), and the other two were removed in November 1994 (Sheridan 1994b).

\subsection{DNFSB RECOMMENDATION 90-7}

In March 1990, the DNFSB provided Recommendation 90-3 (DNFSB 1990a) to the DOE regarding the safety of storing ferrocyanide-bearing high-level radioactive waste in single-shell tanks (SSTs) at the Hanford Site. The DOE submitted an implementation plan to the DNFSB in August 1990 addressing the four parts of Recommendation $90-3$. The DNFSB reviewed this implementation plan and determined that the plan did not adequately respond to the recommendation.

To strengthen its concerns, the DNFSB restated its position in Recommendation 90-7 (DNFSB 1990b), superseding Recommendation 90-3. The DOE accepted the recommendation and agreed to accelerate and expand its programs dealing with high-level radioactive waste safety issues at the Hanford Site. An implementation plan addressing the six parts of Recommendation 90-7 (Cash 1991) was submitted and accepted by the DNFSB in March 1991. A ferrocyanide program plan outlining planned activities to complete the requirements of DNFSB Recommendation 90-7, meet the Wyden Amendment requirements (Public Law 101-510, 1990), and remove the remaining ferrocyanide tanks from the Watch List was submitted to the DNFSB in December 1994 (O'Leary 1994).

\subsection{APPROACH TO RESOLUTION OF THE FERROCYANIDE SAFETY ISSUE}

Efforts have been underway since the mid-1980s to investigate the potential for exothermic ferrocyanide reactions in Hanford Site SSTs (Burger 1984, Burger and Scheele 1988). The approach to safety issue resolution consisted of three major efforts: 1) improved monitoring; 2) increased understanding of ferrocyanide chemical properties (waste phenomenology); and 3) waste characterization.

\subsubsection{Waste Monitoring}

Early in the program, a monitoring and surveillance program was believed necessary to ensure safe storage of the ferrocyanide waste until retrieval and disposal. Technologies for measuring temperature, headspace gas composition and pressure, and waste moisture concentration were investigated as part of the Ferrocyanide Safety Program. However, an improved understanding of waste phenomenology has eliminated the need for most monitoring. 
The original plan (Cash 1991) called for the installation or refurbishment of several thermocouple trees or multifunctional instrument trees (capable of monitoring temperature, pressure, and headspace gases) in each tank. However, this plan was modified in January 1992 to reflect the need for at least one instrument tree with replaceable temperature-sensing elements in each ferrocyanide tank. The data that warranted this action included the following: 1) many of the thermocouple elements in the existing trees were returned to service, and measured temperatures were as expected; 2) thermal modeling (McLaren 1994a, 1994b) and an enhanced understanding of waste properties showed that formation of significant hot spots was not credible in ferrocyanide tanks (Dickinson et al. 1993, Epstein et al. 1994); and 3) refined tank heat content calculations (Crowe et al. 1993, McLaren 1994a, 1994b) showed lower heat loads than early estimates. Installation of new instrument trees was completed in August 1995, and waste temperatures in all ferrocyanide tanks are monitored on a continuous basis with the Tank Monitoring and Control System (Meacham et al. 1995b).

The need to monitor gas composition and pressure was evaluated in June 1994 (Fowler and Graves 1994). The evaluation concluded that continuous monitoring was not warranted based on several factors: 1) the low concentration of flammable gases found during periodic sampling; 2) the low fuel concentration in the waste (from ferrocyanide aging); and 3) calculations showing little hydrogen accumulation in the ferrocyanide tanks. Vapor sampling of all 18 ferrocyanide tanks has also shown that flammable gas concentrations are too low to be of concern (Meacham et al. 1995b).

Three different technologies for determining moisture concentrations were investigated: neutron diffusion, electromagnetic induction (EMI), and near infrared (NIR) spectroscopy. Neutron and EMI prototype probes were built and tested successfully in September 1993 and September 1995, respectively (Watson 1993, Crowe and Wittekind 1995). Initial development of NIR spectroscopy was completed in September 1995 (Reich et al. 1995). Because defendable information on ferrocyanide aging was available by September 1995, additional development of moisture monitoring technology by the Ferrocyanide Safety Program (Meacham et al. 1995b) was canceled. However, moisture monitoring technologies continue to be investigated for the Organic Safety Program.

\subsubsection{Ferrocyanide Chemical Properties}

Chemical reaction studies, begun in October 1988, focused on determining the reactivity of ferrocyanide waste when exposed to Hanford tank farm conditions. Ferrocyanide sludge simulants (U Plant, In Farm, and T Plant), representative of the sludge formed during the 1950 s scavenging campaign, were prepared (Jeppson and Wong 1993) by replicating the original process flowsheets (Sloat 1954 and 1955). Experiments conducted through September 1994 investigated the effects of fuel concentration, water concentration, and potential catalysts, initiators, and diluents (Epstein et al. 1994, Scheele et al. 1993). The results showed that the ferrocyanide sludge retained considerable water (see Section 4.0) and that only the In Farm ferrocyanide sludge originally contained sufficient fuel to sustain a 
propagating reaction (Epstein et al. 1994). Only the four C Farm ferrocyanide tanks received In Farm ferrocyanide waste. By December 1994, propagation experiments (Epstein et al. 1994) were curtailed as waste characterization data confirmed the results of ferrocyanide decomposition (aging) experiments.

Ferrocyanide aging experiments were started in October 1992 to better understand the ferrocyanide hazard as it presently exists. Experiments investigated the effects of temperature, $\mathrm{pH}$, and radiation on ferrocyanide waste reactivity (see Section 4.0). The results indicated that substantial decomposition would occur under tank waste conditions (Lilga et al. 1993). By December 1993, enough information was available to influence the approach to safety resolution. Priorities began to shift towards further refinement of ferrocyanide aging models and additional confirmation of aging through waste characterization.

\subsubsection{Waste Characterization}

The original plan for resolution of the Ferrocyanide Safety Issue was to obtain core samples from all ferrocyanide tanks (Cash 1991). The USQ severely limited the operations in and around ferrocyanide tanks, and detailed safety assessments and DOE approval were required before any samples were obtained. Consequently, sampling and analysis results from the first two ferrocyanide tanks (C-109 and C-112) were not available until February 1993. Analyses indicated ferrocyanide concentrations an order of magnitude lower than the original flowsheets, corroborating the results from the ongoing aging experiments. By December 1993, it was recognized that the sampling and analysis of selected tank waste, in combination with simulant studies, could resolve the Ferrocyanide Safety Issue. The Ferrocyanide Program Plan was revised in October 1994 to reflect the potential for resolving the Ferrocyanide Safety Issue without sampling all ferrocyanide tanks (DOE 1994). 


\subsection{HAZARD POTENTIAL AND POSTULATED FERROCYANIDE ACCIDENTS}

The potential hazard posed by the ferrocyanide-bearing wastes can differ depending on the waste's composition. The composition of the ferrocyanide sludges, as they were originally formed, varied as a result of the different flowsheets used to produce them.

Three processes were conducted in separate facilities to treat three different types of waste. The corresponding flowsheets are termed U Plant, T Plant, and In Farm (Borsheim and Simpson 1991). In general, the aqueous waste was pumped to process tanks where the $\mathrm{pH}$ was adjusted and precipitating agents were added. The slurry was then transferred to an underground storage tank for settling of the solids and disposal of the supernatant liquid to the ground. During the precipitation and settling stages, ${ }^{137} \mathrm{Cs}$ co-precipitated with the ferrocyanide. Because such a large excess of ferrocyanide was added, a high percentage ( 90 to $99 \%$ ) of the ferrocyanide precipitated as sodium nickel ferrocyanide $\left[\mathrm{Na}_{2} \mathrm{NiFe}(\mathrm{CN})_{6}\right]$. The precipitated solids formed a sludge that constituted the ferrocyanide waste. The U Plant flowsheet material is named such because the processing was performed at the U Plant facility and then transferred to the tank farms for settling. Likewise, the T Plant flowsheet material was originally processed at the T Plant facility. The In Farm flowsheet was used to treat waste liquids recovered from the underground tanks. These liquid wastes were treated in the CR Vault facility adjacent to the C Farm tanks.

U Plant and T Plant flowsheets produced precipitates that contained relatively large percentages of inert diluents and thus produced sludge that contained relatively low concentrations of ferrocyanide. Some $74 \%$ (by mass) of ferrocyanide used at the Hanford Site was employed by these two flowsheets.

The In Farm flowsheets contained lower concentrations of inert diluents, and therefore resulted in sludge that contained relatively higher concentrations of ferrocyanide. Roughly $26 \%$ of the total ferrocyanide was used in the In Farm flowsheet.

\subsection{ACCIDENT SCENARIO}

The postulated accident of concern arising from the ferrocyanide hazard is the occurrence of a sustainable, rapid exothermic ferrocyanide-nitrate (or nitrite) reaction in the stored waste. A sustainable reaction is one that can spread beyond a local ignition source. A rapid reaction is one that generates heat faster than it can be removed; it excludes the slow aging (degradation) reactions that occur over a period of years. Such a sustainable, rapid exothermic reaction could produce sufficient heat and evolved gases to pressurize the tank headspace, releasing aerosolized waste from tank vents and potentially damaging the tank's structure. 
For a propagating reaction accident to occur, several conditions would be necessary. The specific limits for these conditions that define when a reaction may or may not be possible are discussed later. All of these conditions must be met or exceeded to have a propagating reaction:

- Tank waste would need a ferrocyanide (fuel) concentration sufficient to support a sustainable rapid exothermic reaction (propagating reaction)

- Sufficient oxidizer would need to be well mixed and in contact with the fuel

- The water (moisture) content of the sludge would need to be sufficiently low (the sludge must be relatively dry) that initiated reactions would not be quenched by wet material

- The reaction would need to be initiated by heating a portion of the waste to the reaction ignition temperature.

If all of these conditions were met, a reaction could propagate through additional reactive sludge until materials not meeting these conditions were encountered. Thus, a postulated accident scenario is as follows (as shown in Figure 3-1):

- Ferrocyanide-bearing waste settled in or was transferred to an SST for storage. The settled sludge had a sufficiently high ferrocyanide (fuel) concentration to support a propagating reaction. The ferrocyanide concentration was not reduced, through aging processes over approximately 40 years of storage, below the minimum required value.

- The sludge contains sufficient nitrate and/or nitrite mixed with the ferrocyanide to provide the oxidizer for the propagating combustion reaction.

- The water content of the settled sludge is reduced by draining or evaporation until the sludge is sufficiently dry.

- A portion of the sludge is heated to ignition temperatures of 250 to $270{ }^{\circ} \mathrm{C}$ (482 to $518^{\circ} \mathrm{F}$ ) (Epstein et al. 1994, Postma et al. 1994) by in-tank activities or by a lightning strike that arcs from suspended in-tank equipment to the waste surface, or by a hot spot that develops by concentrating ${ }^{137} \mathrm{Cs}$ and/or ${ }^{90} \mathrm{Sr}$ in a small portion of the waste.

- Once initiated, the reaction propagates through surrounding reactive sludge. This reaction is not explosive; the measured reaction propagation velocities are quite low, on the order of $10 \mathrm{~cm} / \mathrm{min}$ (Table 3-2). The hot gases produced can pressurize the tank headspace and vaporize volatile radionuclides that condense as aerosols when mixed into the cooler headspace gas. These radioactive aerosols are released from tank vents, including ruptured high-efficiency particulate air filters. If the reaction is rapid and consumes sufficient material, the tank structure can be damaged by the pressurization. 
The following discussion shows that the wastes stored in Hanford Site tanks are sufficiently dilute in ferrocyanide (safe) such that the postulated accident is not possible.

\subsection{FERROCYANIDE SAFETY CRITERIA}

The ferrocyanide safety criteria and safety categories are summarized in this section. The derivation and bases are described more fully in Postma et al. (1994). A combination of theoretical analysis and experimental measurements were used to determine safe storage criteria.

\subsubsection{Theoretical Analysis}

The theoretical approach used to identify waste compositions that could or could not support a propagating reaction was based on an energy balance. A necessary condition for propagation is that the reaction generate enough energy to heat ajacent unreacted fuel to its ignition temperature. The condition is satisfied when the potential reaction energy is greater than the endothermic capacity of the waste from ambient temperature to a reaction threshold temperature (see Equation 1).

$$
\Delta H_{M}+\Delta H_{R}<0
$$

where:

$$
\begin{aligned}
& \Delta \mathrm{H}_{\mathrm{M}}=\text { Change in enthalpy of waste upon heating from initial temperature to reaction } \\
& \text { onset temperature (positive term) } \\
& \Delta H_{\mathrm{R}}=\text { Reaction enthalpy (negative term). }
\end{aligned}
$$

The oxidation of ferrocyanide by nitrate and/or nitrite can result in a variety of reaction products with different reaction energies. The most energetic, for a given amount of fuel, is one that produces nitrogen and carbon dioxide (or carbonate salt if there is sufficient hydroxide available to form it). A representative equation with nitrate is

$$
\mathrm{Na} \mathrm{NiFe}_{2}(\mathrm{CN})_{6}+6 \mathrm{NaNO}_{3} \rightarrow \mathrm{FeO}+\mathrm{NiO}+4 \mathrm{Na}_{2} \mathrm{CO}_{3}+6 \mathrm{~N}_{2}+2 \mathrm{CO}_{2}
$$

The calculated energy $(\Delta \mathrm{H})$ for this reaction is approximately $\mathbf{- 9 . 5 2}$ megajoules (exothermic) per kilogram $(\mathrm{MJ} / \mathrm{kg})$ of ferrocyanide at $25^{\circ} \mathrm{C}\left(298^{\circ} \mathrm{K}\right)$. 
Observations indicate that oxides of nitrogen are formed in slow, low temperature reactions between ferrocyanide and nitrate-nitrite mixes. Calculated reaction energies are lower for reactions that produce nitrogen oxides. The theoretical energy available from the reaction decreases to $-6.6 \mathrm{MJ} / \mathrm{kg}$ when $\mathrm{N}_{2} \mathrm{O}$ is the product. If $\mathrm{NO}$ is produced, the reaction is endothermic and $0.73 \mathrm{MJ} / \mathrm{kg}$ is calculated.

For this assessment, the reaction energy was assigned a value of $-6 \mathrm{MJ} / \mathrm{kg}$ of $\mathrm{Na}_{2} \mathrm{NiFe}(\mathrm{CN})_{6}$ on the basis of three independent experimental determinations on waste simulants (Postma et al. 1994). This amounts to $63 \%$ of the theoretical value given above for Equation (2) and $90 \%$ of the calculated energy with $\mathrm{N}_{2} \mathrm{O}$ as the product gas. The threshold temperature for waste simulants has been measured to be in the range of $220^{\circ} \mathrm{C}$ to $270{ }^{\circ} \mathrm{C}$, and was selected as $250^{\circ} \mathrm{C}$ for this analysis.

Based on a reaction energy of $6 \mathrm{MJ} / \mathrm{kg}$, an initial temperature of $30^{\circ} \mathrm{C}$ and a reaction threshold temperature of $250^{\circ} \mathrm{C}$, energy balance calculations [detailed in Postma et al. (1994)] identified the minimum theoretical fuel concentration necessary to sustain a propagating reaction. For waste with 0 weight percent (wt \%) free water, the minimum fuel concentration is about $8 \mathrm{wt} \%$ sodium nickel ferrocyanide. In terms of safe storage, the fuel criterion is

$$
\mathrm{Na}_{2} \mathrm{NiFe}(\mathrm{CN})_{6} \text { Concentration } \leq 8 w t \%
$$

For waste with greater than $8 \mathrm{wt} \%$ sodium nickel ferrocyanide, the mass of free water required to quench reactions increases linearly with ferrocyanide concentration. This relationship can be approximated by a moisture concentration that increases linearly from zero at $8 \mathrm{wt} \% \mathrm{Na}_{2} \mathrm{NiFe}(\mathrm{CN})_{6}$ to $24 \mathrm{wt} \%$ water at a ferrocyanide concentration of $26 \mathrm{wt} \%$. In terms of safe storage, the moisture criterion is

$$
\text { Water Concentration (wt\%) } \geq \frac{4}{3} \mathrm{Fuel}\left[\mathrm{dry} w \mathrm{t} \% \mathrm{Na}_{2} \mathrm{NiFe}(\mathrm{CN})_{6}\right]-10.7 w t \%
$$

The theoretical approach used for this assessment yielded conservative criteria when compared to the results of combustion experiments on ferrocyanide waste simulants. Results from this testing are described in the next section.

\subsubsection{Experimental Results}

Ferrocyanide waste simulants and pure sodium nickel ferrocyanide were prepared for combustion experiments to corroborate the safe storage criteria. The simulants were 
prepared by reproducing the three process flowsheet recipes (In Farm, U Plant, and T Plant), however, the simulants did not contain radioactive constituents. The precipitates were centrifuged to simulate approximately 40 years of settling. Typically, two or three layers of precipitates (discernable by color) were formed at the bottom of the settling and centrifuging containers. These layers were separated and analyzed. The bottom layer of the U Plant and In Farm simulants and the top layer of the $T$ Plant simulant contained the higher ferrocyanide concentrations (see Table 3-1 for ferrocyanide concentrations).

Reactive System Screening Tool Combustion Tests. A number of compositions containing ferrocyanide and $\mathrm{NaNO}_{3} / \mathrm{NaNO}_{2}$ were tested in the reactive system screening tool (RSST) (Fauske and Leung 1985). In these tests, sizeable samples (10 grams and 70 grams) were heated at $10^{\circ} \mathrm{C} / \mathrm{min}$ under low heat loss conditions. A summary of the tests is shown in Table 3-1. As the sample was heated to above the reaction onset temperature, the thermal energy produced by the reaction caused the sample to self-heat. The rate and extent of this self-heating provides direct evidence of the character of the reaction that has taken place.

Table 3-1. Summary of RSST Tests Regarding Propagationa.

\begin{tabular}{|c|c|c|c|}
\hline 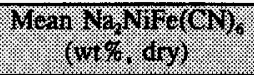 & 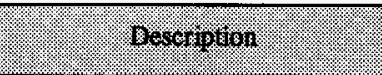 & 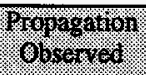 & 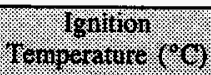 \\
\hline 2.5 & Mixtures ${ }^{\mathrm{b}}$ of pure $\mathrm{Na}_{2} \mathrm{NiFe}(\mathrm{CN})_{6}$ & No & NA $^{\mathrm{c}}$ \\
\hline 4.6 & U Plant 1 & No & NA \\
\hline 5.0 & Mixtures of pure $\mathrm{Na}_{2} \mathrm{NiFe}(\mathrm{CN})_{6}$ & No & NA \\
\hline 6.3 & U Plant 2 top layer & No & NA \\
\hline 8.2 & U Plant 2 bottom layer & No & NA \\
\hline 8.8 & T Plant & No & $\mathbf{N A}$ \\
\hline 10 & Mixtures of pure $\mathrm{Na}_{2} \mathrm{NiFe}(\mathrm{CN})_{6}$ & No & NA \\
\hline 14 & Mixtures of pure $\mathrm{Na}_{2} \mathrm{NiFe}(\mathrm{CN})_{6}$ & No & NA \\
\hline 15.5 & Mixtures of pure $\mathrm{Na}_{2} \mathrm{NiFe}(\mathrm{CN})_{6}$ & Yes & 275 \\
\hline 15.6 & In Farm $+\mathrm{NaNO}_{2}$ diluent & Yes & 270 \\
\hline 18.2 & In Farm 1 top layer & Yes & 254 \\
\hline 18.6 & In Farm 2 top layer & Yes & 278 \\
\hline 18.6 & In Farm $+\mathrm{NaNO}_{2}$ diluent & Yes & 260 \\
\hline 20 & Mixtures of pure $\mathrm{Na}_{2} \mathrm{NiFe}(\mathrm{CN})_{6}$ & Yes & 240 \\
\hline 22.6 & In Farm 2 bottom layer & Yes & 244 \\
\hline 25.5 & In Farm 1 bottom layer & Yes & 250 \\
\hline
\end{tabular}

Notes:

'Data from Fauske (1992), Fauske (1993), Fauske et al. (1995a), and Fauske et al. (1995b).

bixtures were comprised of a combination of pure $\mathrm{Na}_{2} \mathrm{NiFe}(\mathrm{CN})_{6}$ and excess $\mathrm{NaNO}_{3}$.

NA = Not Applicable, sample did not propagate. 
Two distinct types of behavior were seen depending on sample reactivity (i.e., ferrocyanide concentration): (1) A relatively slow heat-up rate that is typical of an Arrhenius or runaway reaction (any material that contains chemicals that react exothermically will exhibit this behavior); and (2) A sharp transition to a very high self-heating rate indicating ignition and the passing of a reaction front. For materials that exhibit this behavior, a propagating reaction is possible, given a sufficient initiator.

The adiabatic calorimetry (RSST) tests on waste simulants (Table 3-1) showed that a fuel concentration of about $15 \mathrm{wt} \% \mathrm{Na}_{2} \mathrm{NiFe}(\mathrm{CN})_{6}$ was necessary to support a propagating reaction, almost twice the $8 \mathrm{wt} \%$ theoretical criterion. It is interesting to note that only the In Farm ferrocyanide waste simulants (representing waste from the four C Farm tanks) supported a propagating combustion. This suggests that the U Plant and T Plant flowsheet sludges never contained sufficient fuel to propagate.

Tube Propagation Combustion Tests. The effect of moisture on ferrocyanide reactions was evaluated with tube propagation tests. The test apparatus consisted of a thin, insulated stainless-steel cylinder, $25 \mathrm{~mm}$ in diameter and $100 \mathrm{~mm}$ tall, that was filled with the test material (Fauske 1992). The reaction was ignited at the top by a $\mathrm{BaO}_{2}-\mathrm{Al}$ mixture. The progress of the reaction, if any, was monitored by four thermocouples spaced 20 to $30 \mathrm{~mm}$ apart. Again, one of two distinct behaviors was observed. The reaction proceeded to the bottom of the cylinder in samples capable of supporting a propagation reaction. If the reaction would not ignite or failed to sustain combustion, the sample did not support a propagating reaction. Test compositions, test conditions, and results are summarized in Table 3-2.

Several compositions were tested by this method, where both ferrocyanide and water concentrations were varied. The tube propagation test results also showed that $\mathrm{Na}_{2} \mathrm{NiFe}(\mathrm{CN})_{6}$ concentrations of about $15 \mathrm{wt} \%$ were required to support propagation. The ferrocyanide concentration required to support propagation increased with the water content of the sludge. A stoichiometric mixture of fuel and oxidizer failed to propagate when $20 \mathrm{wt} \%$ free water was present.

A key finding of these tests is that propagation ceased when the free water concentration was $12 \mathrm{wt} \%$ or more at a ferrocyanide concentration of $25.5 \mathrm{wt} \%$ ferrocyanide (the highest concentration found in the waste simulants). This water concentration was roughly half of the theoretical moisture criterion $(23 \mathrm{wt} \%)$ for a fuel value of $25.5 \mathrm{wt} \%$. This difference was expected because the thermodynamic calculations are inherently conservative. 
Table 3-2. Summary of Ferrocyanide Tube Propagation Tests.

\begin{tabular}{|c|c|c|c|c|c|}
\hline 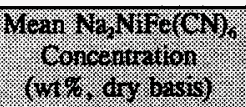 & 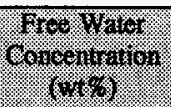 & 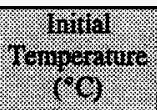 & orosonged & 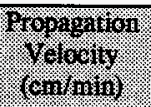 & Nores. \\
\hline 12 & 0 & 30 & No & NA & a \\
\hline 12 & 0 & 130 & No & NA & $\mathbf{a}$ \\
\hline 14 & 0 & 30 & No & NA & a \\
\hline 14 & 0 & 130 & Partial & NA & a \\
\hline 15.5 & 0 & 30 & Yes & 2 & $a$ \\
\hline 26 & 0 & 26 & Yes & 10 & b \\
\hline 26 & 8 & 26 & Yes & 5.3 & b \\
\hline 26 & 12 & 26 & No & NA & b \\
\hline 26 & 14.6 & 26 & No & $\overline{N A}$ & b \\
\hline 26 & 50 & 26 & No & NA & $\mathrm{b}$ \\
\hline 29.5 & 0 & 60 & Yes & 9 & c \\
\hline 35 & 0 & -25 & Yes & 20 & $\bar{d}$ \\
\hline 35 & 15 & -25 & Yes & 7.8 & $\mathrm{~d}$ \\
\hline 35 & 20 & -25 & No & NA & d \\
\hline
\end{tabular}

Notes:

NA $=$ Not Applicable, mixture failed to propagate.

"In Farm simulant (Fauske et al. 1995a).

'Mechanical mixture representing In Farm 1 flowsheet material (Fauske 1992).

'Mixture of $30 \% \mathrm{Na}_{2} \mathrm{NiFe}(\mathrm{CN})_{6}$ with $70 \% \mathrm{NaNO}_{3} / \mathrm{NaNO}_{2}$ oxidizer (Fauske 1992).

'Stoichiometric mixture of pure $\mathrm{Na}_{2} \mathrm{NiFe}(\mathrm{CN})_{6}$ with $\mathrm{NaNO}_{3}$ (Fauske et al. 1995a).

\subsection{WASTE SAFETY CATEGORIES}

\subsubsection{Safe}

Based on theoretical analyses, which were corroborated with ferrocyanide waste simulant experiments (Postma et al. 1994), the criterion that defines the safe category is as follows:

- Fuel concentration $\leq 8 \mathrm{wt} \% \mathrm{Na}_{2} \mathrm{NiFe}(\mathrm{CN})_{6}$ (Temperature, oxidizer, and water concentration are not limiting).

The safety category safe defines waste that cannot burn or explode because it contains too little ferrocyanide as fuel. This conclusion is valid even for waste that contains optimum concentrations of oxidizer and/or no free water. A small amount of bound water (4.6 molecules of $\mathrm{H}_{2} \mathrm{O}$ per molecule of sodium nickel ferrocyanide) has been identified through testing and is credited as being present in ferrocyanide waste that meets safe criteria (Postma et al. 1994). 


\subsubsection{Conditionally Safe}

Based on theoretical analyses, which were corroborated with ferrocyanide waste simulant experiments (Postma et al. 1994), the criterion that defines the conditionally safe category is as follows:

- Water concentration (wt \%) $\geq 4 / 3$ Fuel [in wt $\left.\% \mathrm{Na}_{2} \mathrm{NiFe}(\mathrm{CN})_{6}\right]-10.7 \mathrm{wt} \%$ (Temperature and oxidizer are not limiting).

The safety category conditionally safe defines waste that cannot burn or explode because, although it may contain sufficient fuel and oxidizer, it contains sufficient water (moisture) to quench any reaction that may be initiated, and thus propagating reactions are prevented. This safety category is valid even for waste that contains optimum concentrations of oxidizer.

\subsubsection{Unsafe}

The safety category unsafe defines waste that does not meet the criteria for the safe or conditionally safe categories. 
WHC-SD-WM-SARR-038, Rev. 1

This page intentionally left blank. 


\subsection{ASSESSMENT OF FERROCYANIDE WASTE CONDITIONS}

Whether an exothermic reaction can occur in stored waste depends on the relative concentrations of the reactants, inert solid diluents, and water. The ferrocyanide process flowsheets (Sloat 1954, 1955) were used to determine the original waste composition. Waste transfer records were used to determine which tanks contained ferrocyanide and how much ferrocyanide was originally in each tank. In addition, knowledge from ferrocyanide aging and actual waste sample data allow conclusions to be drawn on the current concentration of ferrocyanide in the Watch List tanks.

\subsection{HISTORICAL RECORDS}

The ferrocyanide scavenging processes were well documented, and records for most of the campaigns still exist (e.g., GE 1958). Three types of waste (U Plant, In Farm, and T Plant) were scavenged to produce ferrocyanide sludges stored in the Hanford Site SSTs. The compositions of each of these waste types was significantly different, and the resulting sludges have different unique compositions. Historical records were used to determine which tanks contained ferrocyanide waste, and to estimate the original ferrocyanide inventories and concentrations (Borsheim and Simpson 1991, Jeppson and Wong 1993, Jeppson et al. 1994, Agnew 1995). Results are summarized in Table 4-1.

It is important to note that each of the ferrocyanide sludge types settled in layers, and the layers contained a distribution of sodium nickel ferrocyanide. Therefore, a single ferrocyanide concentration is not presented for each flowsheet. The ferrocyanide sludge types are more accurately depicted as a range of concentrations as shown in Table 4-1.

As shown in Table 4-1, some portion of the ferrocyanide waste in each of the 18 Watch List tanks probably exceeded the $8 \mathrm{wt} \% \mathrm{Na}_{2} \mathrm{NiFe}(\mathrm{CN})_{6}$ fuel criterion when originally laid down. However, tank sampling data and experiments on waste simulants show that the ferrocyanide has decomposed (aged), and that the current ferrocyanide concentrations are substantially less than the estimated original concentrations. Ferrocyanide aging and current ferrocyanide concentrations are discussed in the next section.

\subsection{FERROCYANIDE AGING}

Experiments, theory, and tank samples indicate that ferrocyanides decompose to inert chemicals under chemical and radiological conditions found in the Hanford Site tanks. This process, called aging, substantially lowers the energy content and ultimately eliminates the hazards associated with ferrocyanide (Babad et al. 1993). The cyanide complex decomposes to a lower energy compound (such as formate), which further decomposes to carbon dioxide or carbonate (Lilga et al. 1996). The carbonate is inert and will not combust. 
Table 4-1. Estimated Original Ferrocyanide Concentrations and Sludge Heights for the Watch List Tanks".

\begin{tabular}{|c|c|c|c|}
\hline (10.18: & 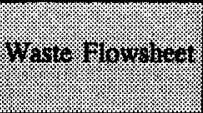 & 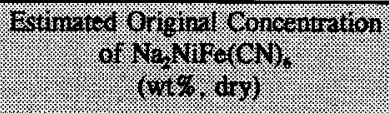 & 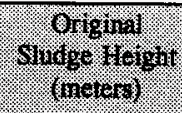 \\
\hline BY-103 & U Plant & $6.0-8.3$ & 2.1 \\
\hline BY-104 & U Plant & $4.0-8.3$ & 2.6 \\
\hline BY-105 & U Plant & $4.0-8.3$ & 1.1 \\
\hline BY-106 & U Plant & $5.2-8.3$ & 2.3 \\
\hline BY-107 & U Plant & $5.0-8.3$ & 1.6 \\
\hline BY-108 & U Plant & $5.0-8.3$ & 2.1 \\
\hline BY -110 & U Plant & $5.7-8.3$ & 2.3 \\
\hline BY-111 & U Plant & $6.3-8.3$ & 0.3 \\
\hline BY -112 & U Plant & $3.5-8.3$ & 0.2 \\
\hline C-108 & In Farm 2 & $10.4-22.6$ & 0.9 \\
\hline C-109 & In Farm 2 & $14.0-22.6$ & 1.2 \\
\hline $\mathrm{C}-111$ & In Farm 2 & $8.9-22.6$ & 1.1 \\
\hline C-112 & In Farm 1 & $16.1-25.5$ & 1.0 \\
\hline $\mathrm{T}-107$ & U Plant & $6.3-8.3$ & 2.1 \\
\hline TX-118 & b & b & b \\
\hline TY-101 & T Plant & $1.6-10.7$ & 1.6 \\
\hline TY-103 & T Plant & $1.6-10.7$ & 1.8 \\
\hline TY-104 & T Plant & $1.6-10.7$ & 0.9 \\
\hline
\end{tabular}

Notes:

- Data compiled from Borsheim and Simpson 1991, Jeppson and Wong 1993, Jeppson et a1. 1994, and Agnew 1995.

- Historical records show that no significant quantity of ferrocyanide sludge was stored in this tank (Borsheim and Simpson 1991, Agnew 1995). The tank was erroneously identified as a ferrocyanide tank because of a transcription error in the track radioactive components (TRAC) calculations (Jungfleisch 1984). 
The parameters that affect the rate of aging have been examined through testing on ferrocyanide waste simulants. In addition, tank waste histories and tank sample data have been evaluated to bound the amount of aging that has occurred in all the ferrocyanide tanks.

\subsubsection{Parameters Affecting the Rate of Aging}

The available literature (MacDiarmid and Hall 1953, Masri and Haissinsky 1963, Hughes and Willis 1961, Ohno and Tsuchihasi 1965, Robuck and Luthy 1979) indicate that three main parameters can affect the rate of aging: exposure to high $\mathrm{pH}$ solutions, radiation dose rate, and temperature. Experiments were conducted to determine how aging is affected by the $\mathrm{pH}$, dose rate, and temperature conditions found in the ferrocyanide tanks. These experiments are reviewed in Appendix D and are detailed in Lilga et al. (1996). The key conclusions from the aging experiments are summarized below.

Experiments with waste simulants (Lilga et al. 1996) and open literature (Robuck and Luthy 1979) show that the rate of thermal ferrocyanide aging does not increase at higher $\mathrm{pH}$ when the $\mathrm{pH}$ exceeds nine. The precipitation of sodium nickel ferrocyanide was done at slightly alkaline conditions ( $\mathrm{pH}=8.0-10$ ), however, the ferrocyanide tanks were used for a variety of waste management operations that exposed the tanks to alkaline waste (Anderson 1990). Review of the available historical $\mathrm{pH}$ and hydroxide data collected for the eighteen ferrocyanide tanks shows that all the tanks had $\mathrm{pH}$ values greater than nine (Wodrich et al. 1992). Consequently, waste $\mathrm{pH}$ was not a limiting factor for ferrocyanide waste aging in Hanford Site tanks.

Experiments were conducted on ferrocyanide waste simulants at various gamma dose rates to evaluate the effect of dose rate on the rate of aging (See Appendix D and Lilga et al. 1996). Figure 4-1 summarizes the effect of dose rates ranging from 0 to $10^{5} \mathrm{Rad} / \mathrm{h}$.

The results of these experiments are revealing in that the rate of aging is only noticeably affected at the highest dose rate $\left(10^{5} \mathrm{Rad} / \mathrm{h}\right)$. There was little impact from dose rate observed for dose rates between 0 and $1,000 \mathrm{Rad} / \mathrm{h}$; all the points essentially fall on the same curve. Dose rates in the ferrocyanide waste tanks were calculated to be in the $1,000 \mathrm{Rad} / \mathrm{h}$ range, and none approached 10,000 Rad/h (Parra 1994). Consequently, dose rates in the ferrocyanide tanks had only a second order effect on the rate of aging.

Experiments on waste simulants show that the rate of aging was strongly affected by temperature (see Appendix D and Lilga et al. 1996). As shown in Table 4-2, the rate of aging increased dramatically with increasing temperature. The experiments show that the extent of ferrocyanide aging in Hanford Site tanks was primarily determined by the individual tank temperature histories. 
Figure 4-1. Rate Constants (k) versus Temperature at Various Gamma Dose Rates.

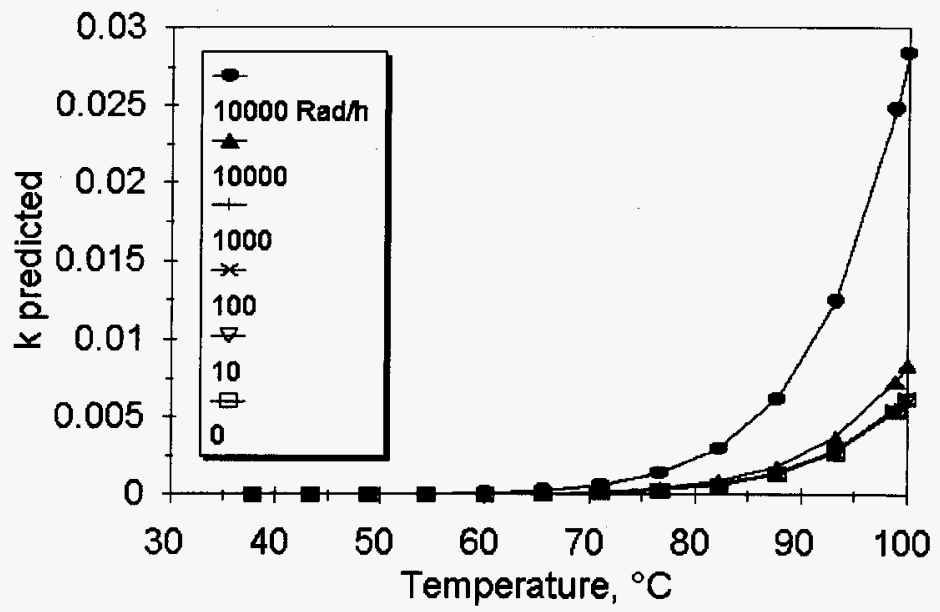

Table 4-2. Aging Rates as a Function of Temperature for Waste Simulant Experiments.

\begin{tabular}{|c|c|}
\hline $\begin{array}{c}\text { Temperature } \\
{ }^{\circ} \mathrm{C}\left({ }^{\circ} \mathrm{F}\right)\end{array}$ & $\begin{array}{c}\text { Reaction Rate } \\
\mathrm{g} \mathrm{Na}_{2} \mathrm{NiFe}(\mathrm{CN})_{6} / 100 \mathrm{~g} \text { dry solids } / \mathrm{yr}\end{array}$ \\
\hline $40(104)$ & 0.04 \\
\hline $50(122)$ & 0.19 \\
\hline $60(140)$ & 0.90 \\
\hline $70(158)$ & 3.9 \\
\hline $80(176)$ & 15.5 \\
\hline $90(194)$ & 57 \\
\hline
\end{tabular}

The impact of these experiments is significant in that it allows a method for selecting those tanks that bound ferrocyanide aging. Those tanks with lowest temperature histories would have the least amount of aging. Therefore, sampling data from the coolest ferrocyanide tanks can be extrapolated to those tanks that have not been sampled to make conclusions on 
the extent of aging for all ferrocyanide tanks. A discussion of ferrocyanide tank temperature histories is presented in the next section.

\subsubsection{Tank Waste Temperature Histories}

\section{BY Tank Farm}

From 1965 to 1975 , the BY ferrocyanide tanks were part of an In-Tank Solidification (ITS) program whose purpose was to create additional tank space by reducing the liquid volume by converting it to a saltcake solid. The ITS-2 (In-Tank Solidification Unit \#2) process was based on the evaporation of water from the waste by directly heating the waste with electrical heaters installed in BY-102 and BY-112. Saltcake was produced when this heated liquid was circulated through a sequence of BY Farm tanks, each with a progressively lower temperature. The elevated temperatures the BY Farm tanks experienced during the ITS-2 solidification program was not from waste isotope decay heat, although this would have assisted in elevating tank temperatures as the waste became more concentrated. The ITS- 2 waste heating resulted in an elevation of BY Tank temperatures, enough to accelerate the aging of ferrocyanide wastes. The individual tank temperature histories are summarized below and are discussed in detail in Appendix $C$.

BY-112: The ITS-2 waste heating unit which was installed in tank BY-112 significantly raised its waste temperature. Temperatures throughout its volume were well above $110^{\circ} \mathrm{C}\left(230^{\circ} \mathrm{F}\right)$ for at least five years.

BY-111: Although no direct temperature data were found for tank BY-111, data from the design and operation of the ITS-2 system showed that it would have had temperatures between those of $B Y-112$ and $B Y-110$. In the cascade of hot wastes, BY-111 was positioned between BY-112 and BY-110. Consequently a conservative position is to assume that BY-111 had temperatures equal to BY-110 which were in the 93 to $99^{\circ} \mathrm{C}\left(200\right.$ to $\left.210^{\circ} \mathrm{F}\right)$ range for about three years.

BY-110: Tank BY-110 received liquid transfers directly from BY-112 during the later operating period of ITS -2 and had ferrocyanide sludge temperatures in the 93 to $99^{\circ} \mathrm{C}$ range for over three years.

BY-108: Tank BY-108 was part of the ITS-2 liquid transfer cycle until 1971 when is was declared a leaker. The temperature data available for BY-108, which start one year after the tank was removed from ITS-2 service, show temperatures above $54{ }^{\circ} \mathrm{C}\left(129^{\circ} \mathrm{F}\right)$ for at least three years. In the ITS-2 design, BY-108 was located between BY-107 and BY-109 and would have waste temperatures between those in BY-107 $\left(104^{\circ} \mathrm{C}\right)$ and BY-109 $\left(54^{\circ} \mathrm{C}\right)$ as shown in Appendix C (Note: BY-109 is not a ferrocyanide tank). Tank BY-108 was the coolest of the ferrocyanide BY tanks and would bound ferrocyanide aging for the BY Farm. 
BY-107: Tank BY-107 received waste transfers directly from BY-111 and from BY-110 during its service as an ITS-2 tank. It would have experienced the same temperatures as BY-104, which were in the $94{ }^{\circ} \mathrm{C}\left(200^{\circ} \mathrm{F}\right)$ range for over three years.

BY-106: Tank BY-106 received wastes from BY-105 while transfers were made to BY-109, and the ferrocyanide sludge layers experienced temperatures in the $66{ }^{\circ} \mathrm{C}\left(151^{\circ} \mathrm{F}\right)$ range for over four years. One full-depth core sample was obtained from this tank.

BY-105: Tank BY-105 was between BY-104 and BY-106 in the ITS-2 cycle, and the ferrocyanide sludge layers were well above $66^{\circ} \mathrm{C}$ for three to four years.

BY-104: Ferrocyanide sludge temperatures exceeded $88^{\circ} \mathrm{C}\left(190^{\circ} \mathrm{F}\right)$ for three to four years. Core samples were obtained from tank BY-104.

BY-103: Based on the location of BY-103 in the ITS-2 liquid cycle, its waste temperatures would have been between that of BY-105 and BY-106. The earliest temperature data (1974) for BY-103 show temperatures in the $54{ }^{\circ} \mathrm{C}\left(129^{\circ} \mathrm{F}\right)$ and higher ranges for over three years.

\section{Tank Farm}

From 1961 to 1965, tank waste status records show that tanks C-108, C-109, C-110, and C-111 received periodic waste transfers from the hot semiworks (Brevick et al. 1995). The feedstock for this plant was fresh process wastes from the PUREX plant, referred to as "PUREX crude" which would have contained a full complement of short and long half-life, heat generating isotopes. In addition, archived documentation on the hot semiworks indicates that the hot semiworks wastes were concentrated in A Cell (using thermal evaporation) before the waste was discharged to a tank.

Measured tank headspace air temperatures in tanks C-109, C-111, and C-112 were over $60{ }^{\circ} \mathrm{C}$. No temperature data were found for Tank C-108. However, waste transfer records show that C-108 received an equivalent amount of hot semiworks waste and would have experienced temperatures similar to the other $C$ Farm tanks.

\section{TY Tank Farm}

Limited temperature data are available for tanks TY-101, TY-103 and TY-104. Temperatures from 1970 to present have ranged from 18 to $21^{\circ} \mathrm{C}\left(64\right.$ to $70{ }^{\circ} \mathrm{F}$ ) (Flanagan 1994). However, temperatures before 1970 would have been higher. Transfer records indicated that TY-104 experienced the lowest temperatures of the three TY ferrocyanide tanks (see Appendix C), and would bound ferrocyanide aging for the TY Farm. 


\section{Tank TX-118}

Tank TX-118 was erroneously placed on the Ferrocyanide Watch List because it was identified in the Track Radioactive Components (Jungfleisch 1984) model as having received ferrocyanide waste. Subsequent review of the waste transfer records show that no ferrocyanide material was ever transferred to TX-118 (Borsheim and Simpson 1991), however, its temperature history is included here because the tank is currently on the Ferrocyanide Watch List.

Tank TX-118 received evaporator bottoms and tributyl phosphate wastes directly from $221-\mathrm{U}$ (U Plant) for over three years. The temperatures ranged from 54 to $60{ }^{\circ} \mathrm{C}$ during this time period.

\subsubsection{Confirmation of Ferrocyanide Aging from Waste Sample Data}

Ferrocyanide aging can be confirmed by examining nickel and cyanide concentrations. Nickel is a signature analyte of the nickel ferrocyanide scavenging process (the major source of high nickel concentrations) and indicates how much ferrocyanide was originally present in the waste. Cyanide analyses indicate how much ferrocyanide is remaining.

Nine ferrocyanide tanks have been sampled full depth (i.e., to the bottom of the tank) and one tank (BY-106) has been partially sampled (see Appendix A for description). Samples from all ten tanks (Table 4-3) confirm that ferrocyanide aging is significant and pervasive. All the sample data indicate that ferrocyanide concentrations are more than an order of magnitude lower than original concentrations, and are significantly below the $8 \mathrm{wt} \%$ safe criterion.

The range given for the extent of aging was calculated by comparing the lowest original concentration to the highest measured concentration, and then comparing the lowest measured concentration to the highest original concentration. For example, the lowest original $\mathrm{Na}_{2} \mathrm{NiFe}(\mathrm{CN})_{6}$ concentration in $\mathrm{BY}-108$ was 5.0 and the highest measured concentration is 0.5 ; this is equivalent to $90 \%$ aging.

From the nickel concentrations measured in the waste, it is apparent that some dilution of the ferrocyanide sludge has occurred. As discussed in Appendix $\mathrm{C}$, some dilution was anticipated because tank-to-tank waste transfers have occurred through the years (e.g., TY-104 received sluiced ferrocyanide waste from TY-101). However, the extent of aging can still be determined by examining the ratio of cyanide $(\mathrm{CN})$ to nickel $(\mathrm{Ni})$. The original ferrocyanide sludge contained a cyanide-to-nickel ratio of 2.66 to 1 . The current cyanide-to-nickel ratios range from $<0.01$ to 1 for $\mathrm{BY}-104$ to 0.22 to 1 for $\mathrm{C}-109$. These small cyanide-to-nickel ratios confirm that extensive aging has occurred in all of the ferrocyanide waste samples. 
Table 4-3. Sample Data Confirming Ferrocyanide Aging.

\begin{tabular}{|c|c|c|c|c|c|}
\hline 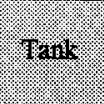 & (1.) & Measurid & $\frac{1}{40+16}$ & 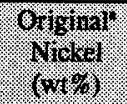 & 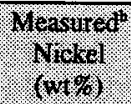 \\
\hline BY-104 & $4.0-8.3$ & $<0.01$ & $99+$ & $1.2-1.5$ & $0.8-1.8$ \\
\hline BY-106 & $5.2-8.3$ & $<0.01$ & $99+$ & $1.2-1.5$ & 3.1 \\
\hline BY-108 & $5.0-8.3$ & $0.01-0.5$ & $90-99+$ & $1.2-1.5$ & $0.2-2.2$ \\
\hline BY-110 & $5.7-8.3$ & $0.00-0.4$ & $98-99+$ & $1.2-1.5$ & $0.1-2.1$ \\
\hline C-108 & $10.4-22.6$ & $0.3-1.1$ & $89-99$ & $3.4-4.2$ & $1.0-2.9$ \\
\hline C-109 & $14.0-22.6$ & $0.7-1.6$ & $89-97$ & $3.4-4.2$ & $1.0-3.9$ \\
\hline $\mathrm{C}-111$ & $8.9-22.6$ & $0.02-0.05$ & $99+$ & $3.4-4.2$ & $2.0-4.3$ \\
\hline C-112 & $16.1-25.5$ & $1.2-1.5$ & $91-95$ & $3.4-4.7$ & $1.0-3.9$ \\
\hline T-107 & $6.3-8.3$ & $0.00-0.02$ & $99+$ & $1.2-1.5$ & $0.2-2.9$ \\
\hline TY-104 & $1.6-10.7$ & $0.00-0.03$ & $98-99+$ & $0.3-2.0$ & $0.3-0.5$ \\
\hline
\end{tabular}

Notes:

A Data compiled from Borsheim and Simpson (1991), Jeppson and Wong (1993), Jeppson et al. (1994), and Agnew (1995).

b Data from Appendix A; cyanide was measured as total cyanide and converted to $\mathrm{Na}_{2} \mathrm{NiFe}(\mathrm{CN})_{6}$.

\subsubsection{Ferrocyanide Aging Estimates for Unsampled Watch List Tanks}

It is possible to estimate the extent of aging in the unsampled tanks using the results of the ferrocyanide aging experiments, and the tank temperature histories. Estimated current ferrocyanide concentrations for the unsampled tanks are reviewed in Table 4-4. The data in Table 4-4 were generated by correlating the extent (percent) of aging and temperatures observed in the sampled tanks, with the temperatures of the unsampled tanks.

As discussed in Section 4.2.2, the unsampled tanks have similar or higher waste temperature histories than the sampled tanks. All of the BY ferrocyanide tanks had temperatures higher or equal to tank BY-108, which showed a minimum of $90 \%$ aging (see Table 4-3). All of the TY tanks had temperatures greater than TY-104, which showed a minimum of $98 \%$ aging. The estimated concentrations shown in Table 4-4 were generated using the minimum percent aging calculated for the BY and TY Farm ferrocyanide tanks. 
Table 4-4. Estimated Current Ferrocyanide Concentrations in the Unsampled Tanks.

\begin{tabular}{|c|c|}
\hline Tank & \begin{tabular}{c} 
Estimated Current $\begin{array}{c}\mathrm{Na}_{2} \mathrm{NiFe}(\mathrm{CN})_{6} \text { Concentration } \\
(\mathrm{wt} \%, \text { dry })\end{array}$ \\
\hline BY-103
\end{tabular} \\
\hline BY-105 & $0.6-0.8$ \\
\hline BY-107 & $0.4-0.8$ \\
\hline BY-111 & $0.5-0.8$ \\
\hline BY-112 & $0.6-0.8$ \\
\hline TY-103 & $0.4-0.8$ \\
\hline TY-104 & $0.0-0.2$ \\
\hline
\end{tabular}

\subsubsection{Conclusion on Ferrocyanide Waste Aging}

Based on tank waste histories and laboratory experiments with simulated ferrocyanide flowsheet materials, it has been shown that conditions existed within the tanks that would promote ferrocyanide aging. Tank sampling data and waste history data indicate that the ferrocyanide concentrations have aged to levels lower than $8 \mathrm{wt} \%$, and that the ferrocyanide tanks should be categorized as safe. 
WHC-SD-WM-SARR-038, Rev. 1

This page intentionally left blank. 


\subsection{WASTE HAZARD POTENTIAL AND ACCIDENT FREQUENCY}

Based on estimates and measurements of the ferrocyanide concentration, the ferrocyanide wastes have been compared to the safety criteria and categorized as shown in Table 5-1. For tanks with sampling data, the upper $95 \%$ confidence of the tank mean was calculated and compared to the $8 \mathrm{wt} \%$ fuel criterion (see Appendixes A and B). As indicated, all ferrocyanide wastes meet the safe criteria.

Table 5-1. Summary of Ferrocyanide Tank Categorization and Required Controls.

\begin{tabular}{|c|c|c|c|c|}
\hline I) & 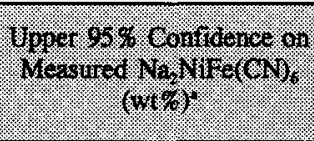 & 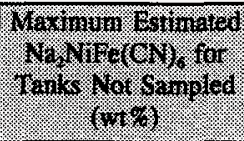 & $\frac{1}{6010 y}$ & Gorisols. \\
\hline BY -103 & NA & 0.8 & safe & None \\
\hline BY-104 & 0.05 & NA & safe & None \\
\hline BY-105 & NA & 0.8 & safe & None \\
\hline BY-106 & NA & 0.8 & safe & None \\
\hline BY-107 & NA & 0.8 & safe & None \\
\hline BY -108 & 1.9 & NA & safe & None \\
\hline BY-110 & 0.10 & NA & safe & None \\
\hline BY -111 & NA & 0.8 & safe & None \\
\hline BY -112 & NA & 0.8 & safe & None \\
\hline C-108 & 2.8 & NA & safe & None \\
\hline C-109 & 2.3 & NA & safe & None \\
\hline C-111 & 0.06 & NA & safe & None \\
\hline C-112 & 2.0 & NA & safe & None \\
\hline $\mathrm{T}-107$ & 0.05 & NA & safe & None \\
\hline TX-118 & $\mathrm{b}$ & b & safe & None \\
\hline TY-101 & NA & 0.2 & safe & None \\
\hline TY -103 & NA & 0.2 & safe & None \\
\hline TY-104 & 0.09 & NA & safe & None \\
\hline
\end{tabular}

Note:

NA = Not applicable, sufficient sample data are not available to preform this statistical analysis.

Data from Appendix A.

- Historical records show that no significant quantity of ferrocyanide sludge was stored in this tank (Borsheim and Simpson 1991, Agnew 1995). The tank was erroneously identified as a ferrocyanide tank because of a transcription error in the track radioactive components (TRAC) calculations (Jungfleisch 1984). 


\subsection{TANKS CONTAINING IN FARM SLUDGE}

The four tanks containing the highest original ferrocyanide concentrations (241-C-108, $\mathrm{C}-109, \mathrm{C}-111$, and $\mathrm{C}-112)$ are put into the safe category on the basis of sample data for all four tanks. Multiple core and auger samples, taken from opposite tank quadrants, were divided into vertical subsegments. Statistical evaluations of the sample results are described in Appendixes A and B. The statistical analysis in Appendix A concludes that the $95 \%$ confidence level estimate for fuel is no higher than $2.8 \mathrm{wt} \%$, on a dry weight basis. The highest measured $\mathrm{Na}_{2} \mathrm{NiFe}(\mathrm{CN})_{6}$ concentration was $1.6 \mathrm{wt} \%$. This is below the $8 \mathrm{wt} \%$ criterion for safe waste; therefore, the wastes in the four C Farm ferrocyanide tanks are categorized as safe.

Appendix B treats the same sample data from the four C Farm tanks in a slightly different manner, but also concludes there is a very low probability (less than $10^{-6}$ ) that the ferrocyanide exceeds $8 \mathrm{wt} \%$.

Based on Revision OA of this document (Grigsby et al. 1996), DOE approved removal of the four C Farm tanks from the Watch List in June 1996 (Kinzer 1996).

\subsection{TANKS CONTAINING U PLANT SLUDGE}

Four tanks (BY-104, BY-108, BY-110, and T-107) are put into the safe category on the basis of sample data for the tanks. Multiple core samples, taken from opposite tank quadrants, were divided into vertical subsegments. Statistical evaluations of the sample results are described in Appendixes A and B. The statistical analysis in Appendix A concludes that the $95 \%$ confidence level estimate for fuel is no higher than $1.9 \mathrm{wt} \%$, on a dry weight basis. The highest measured $\mathrm{Na}_{2} \mathrm{NiFe}(\mathrm{CN})_{6}$ value for these tanks was $0.5 \mathrm{wt} \%$. The remaining U Plant tanks (BY-103, BY-105, BY-106, BY-107, BY-111, BY-112, and TX-118) are put into the safe category based on the data from the sampled tanks. Because the sampled tanks had similar or lower temperature histories, the unsampled tanks would also have ferrocyanide concentrations substantially lower than the $8 \mathrm{wt} \%$ safe criterion.

\subsection{TANKS CONTAINING T PLANT SLUDGE}

The three tanks containing $\mathrm{T}$ Plant sludge are also categorized as safe based on sampling and an understanding of aging. Two full-depth auger samples were obtained from TY-104 and analyzed for cyanide and nickel. The statistical analysis in Appendix A concludes that the 
$95 \%$ confidence level estimate for fuel is no higher than $0.09 \mathrm{wt} \%$, on a dry weight basis. Tank TY-104 was and continues to be the coolest of three TY Farm ferrocyanide tanks, and because the rate of aging most sensitive to waste temperature, similar aging has also occurred in TY-101 and TY-103.

\subsection{HAZARD POTENTIAL AND ACCIDENT FREQUENCY CONCLUSIONS}

The ferrocyanide wastes for all Ferrocyanide Watch List tanks meet the safe criteria and therefore cannot support a sustained rapid exothermic (propagating) reaction. Ferrocyanide wastes meet these criteria through inherent waste properties; that is, without any reliance on active waste management such as temperature and moisture management/control. Therefore, no temperature or moisture controls are required for the ferrocyanide tanks. 
WHC-SD-WM-SARR-038, Rev. 1

This page intentionally left blank. 


\subsection{SAFETY CONCLUSIONS AND REQUIRED CONTROLS}

The analysis presented in this report shows that all ferrocyanide wastes in Hanford Site underground storage tanks meet safe criteria. These wastes cannot support a sustained, rapid exothermic (propagating) reaction. Ferrocyanide wastes meet these criteria through inherent waste properties; that is, without any reliance on active waste management. Therefore, temperature and moisture controls are not required. 
WHC-SD-WM-SARR-038, Rev. 1

This page intentionally left blank. 


\subsection{REFERENCES}

Agnew, S. F., 1995, Hanford Defined Wastes: Chemical and Radionuclide Compositions, LA-UR-94-2657, Rev. 2, Los Alamos National Laboratory, Los Alamos, New Mexico.

Anderson, J. D., 1990, A History of the 200 Area Tank Farms, WHC-MR-0132, Westinghouse Hanford Company, Richland, Washington.

Anttonen, J. H., 1993, Resolution of Unreviewed Safety Question (USQ) for Four Ferrocyanide Tanks, (letter 9304645B/93-CAB-223 to T. M. Anderson, President, Westinghouse Hanford Company, July 9), U.S. Department of Energy, Richland Operations Office, Richland, Washington.

Babad, H., J. E. Meacham, B. C. Simpson, and R. J. Cash, 1993, The Role of Aging in Resolving the Ferrocyanide Safety Issue, WHC-EP-0599, Westinghouse Hanford Company, Richland, Washington.

Borsheim, G. L., and R. J. Cash, 1991, Unusual Occurrence - Addition of Two Tanks to List of Unreviewed Safety Question Tanks Containing Ferrocyanide, WHC-91-0096-TFARM, February 13, Westinghouse Hanford Company, Richland, Washington.

Borsheim, G. L., and B. C. Simpson, 1991, An Assessment of the Inventories of the Ferrocyanide Watch List Tanks, WHC-SD-WM-ER-133, Rev. 0, Westinghouse Hanford Company, Richland, Washington.

Brevick, C. H., 1995a, Historical Tank Contents Estimates for the Northeast Quadrant of the Hanford 200 East Areas, WHC-SD-WM-ER-349, Rev. OA, March 1995, Westinghouse Hanford Company, Richland, Washington.

Brevick, C. H., 1995b, Historical Tank Contents Estimates for the Northwest Quadrant of the Hanford 200 West Area, WHC-SD-WM-ER-351, Rev. 0, March 1995, Westinghouse Hanford Company, Richland, Washington.

Burger, L. L., 1984, Complexant Stability Investigation, Task I - Ferrocyanide Solids, PNL-5441, Pacific Northwest Laboratory, Richland, Washington.

Burger, L. L, and R. D. Scheele, 1988, Interim Report - Cyanide Safety Studies, PNL-7175, Pacific Northwest Laboratory, Richland, Washington.

Cady, H. H., 1993, Evaluation of Ferrocyanide/Nitrate Explosive Hazard, LA-12589-MS, Los Alamos National Laboratory, Los Alamos, New Mexico. 
Cash, R. J., 1991, Implementation Plan for Defense Nuclear Facilities Safety Board Recommendation 90-7, WHC-EP-0415, Westinghouse Hanford Company, Richland, Washington.

Crowe, R. D., and W. D. Wittekind, 1995, Ferrocyanide Safety Program: In-Tank Application of Electromagnetic Induction (EMI) Moisture Measurements - FY 1995 Report, WHC-SD-WM-ER-520, Rev. 0, Westinghouse Hanford Company, Richland, Washington.

Dickinson, D. R., J. M. McLaren, G. L. Borsheim, and M. D. Crippen, 1993, Ferrocyanide Safety Program: Credibility of Drying Out Ferrocyanide Tank Waste by Hot Spots, WHC-EP-0648, Rev. 0, Westinghouse Hanford Company, Richland, Washington.

DOE, 1987, Final Environmental Impact Statement - Disposal of Hanford Defense High-Level, Transuranic and Tank Wastes, Vols. 1-5, DOE/EIS-0113, U.S. Department of Energy, Washington, D.C.

DOE, 1994, Program Plan for Resolution of the Ferrocyanide Waste Tank Safety Issue at the Hanford Site, DOE/RL-94-110, Rev. 1, U.S. Department of Energy, Richland Operations Office, Richland, Washington.

Crowe, R. D., M. Kummerer, and A. K. Postma, 1993, Ferrocyanide Safety Program: Estimate of Heat Load in Waste Tanks Using Average Vapor Space Temperature, WHC-EP-0709, Westinghouse Hanford Company, Richland, Washington.

Deaton, D. E., Unusual Occurrence - Unreviewed Safety Questions Regarding Tanks Containing Ferrocyanide, WHC-90-B003-R1, Update 10-22-90, Westinghouse Hanford Company, Richland, Washington.

DNFSB, 1990a, "Implementation Plan for Recommendation 90-3 at the U.S. Department of Energy's Hanford Site, Richland, Washington," Federal Register, Defense Nuclear Facilities Safety Board Recommendation 90-7, Vol. 55, No. 202, pp. 42243-42244, Washington, D.C.

DNFSB, 1990b, "Future Monitoring Programs at the Department of Energy's Hanford Site, WA," Federal Register, Vol. 55, No. 62, Washington, D.C., pp. 11994-11995.

Epstein, M., H. K. Fauske, D. R. Dickinson, M. D. Crippen, J. D. McCormack, R. J. Cash, J. E. Meacham, and C. S. Simmons, 1994, Ferrocyanide Safety Program: An Assessment of the Possibility of Ferrocyanide Sludge Dryout, WHC-EP-0816, Westinghouse Hanford Company, Richland, Washington. 
Fauske, H. K., 1992, Adiabatic Calorimetry and Reaction Propagation Tests with Synthetic Ferrocyanide Materials Including U Plant 1, U Plant 2, In-Farm 1, In-Farm 2, and Vendor-Procured Sodium Nickel Ferrocyanide, WHC-SD-WM-RDT-054, Rev. 0, Westinghouse Hanford Company, Richland, Washington.

Fauske, H. K., 1993, Adiabatic Calorimetry (RSST and VSP) Tests with Synthetic T Plant Flow Sheet Material, (letter to R. J. Cash, Westinghouse Hanford Company, July 28), Fauske and Associates, Inc., Burr Ridge, Illinois.

Fauske, H. K., M. Epstein, D. R. Dickinson, R. J. Cash, D. A. Turner, and J. E. Meacham, 1995a, The Contact-Temperature Ignition (CTI) Criteria for Propagating Chemical Reactions Including the Effect of Moisture and Application to Hanford Waste, WHC-SD-WM-ER-496, Rev. 0, Westinghouse Hanford Company, Richland, Washington.

Fauske, H. K., J. E. Meacham, and R. J. Cash, 1995b, Ferrocyanide Safety Program: Final Report of Adiabatic Calorimetry and Tube Propagation Tests With Synthetic Ferrocyanide Materials, WHC-SD-WM-ER-519, Rev. 0, Westinghouse Hanford Company, Richland, Washington.

Fauske, H. K., and J. C. Leung, 1985, "New Experimental Techniques for Characterizing Runaway Chemical Reactions," Chemical Engineering Progress, vol. 81, p. 39.

Flanagan, B. D., 1994, Maximum Surface Level and Temperature Histories for Hanford Waste Tanks, WHC-SD-WM-TI-591, Westinghouse Hanford Company, Richland, Washington.

Fowler, K. D., and R. D. Graves, 1994, Decision Analysis for Continuous Cover Gas Monitoring of Ferrocyanide Watch List Tanks, WHC-EP-0743, Westinghouse Hanford Company, Richland, Washington.

GE, 1958, Record of Scavenged TBP Waste, General Electric Company, Richland, Washington.

Grigsby, J. M., A. K. Postma, R. J. Cash, J. E. Meacham, D. R. Dickinson, M. A. Lilga, H. K. Fauske, and M. Epstein, 1996, Assessment of the Potential for Ferrocyanide Propagating Reaction Accidents, WHC-SD-WM-SARR-038, Rev. 0 and 0A, Westinghouse Hanford Company, Richland, Washington.

Grumbly, T. P., 1993, Strategy for [Ferrocyanide] Safety Issue Resolution, (letter to J. T. Conway, Chairman, Defense Nuclear Facilities Safety Board, August 25), U.S. Department of Energy, Washington, D.C.

Hanlon, B. M., 1996 Waste Tank Summary Report for Month Ending December 31, 1995, WHC-EP-0182-93, Westinghouse Hanford Company, Richland, Washington. 
Jeppson, D. W., and J. J. Wong, 1993, Ferrocyanide Waste Simulant Characterization, WHC-EP-0631, Westinghouse Hanford Company, Richland, Washington.

Jeppson, D. W., and B. C. Simpson, 1994, Characterization and Reaction Behavior of Ferrocyanide Simulants of Hanford Site High-Level Ferrocyanide Waste, WHC-SA-2190-FP, Westinghouse Hanford Company, Richland, Washington.

Jungfleisch, F. M., 1984, TRAC: A Preliminary Estimation of the Waste Inventories in Hanford Tanks through 1980, WHC-SD-WM-TI-057, Rockwell Hanford Operations, Richland, Washington.

Kinzer, J., 1996, Authorization to Remove Four Ferrocyanide Tanks, 24I-C-108, 241-C-109, 241-C-111, and 241-C-112 from the "Watch List", (letter 96-WSD-116 to A. L. Trego, WHC, June 25), U.S. Department of Energy, Richland, Washington.

Klem, M. J., 1991, Vapor Space Sampling Criteria for Single-Shell Tanks Containing Ferrocyanide Waste, WHC-EP-0424, Rev. 0, Westinghouse Hanford Company, Richland, Washington.

Kuhn, A., and C. Rice, 1977, "Alkaline Hydrolysis of Cyanates, and Dicyan," Oberflache-Surface, vol. 18, pp. 119-123.

Lilga, M. A., M. R. Lumetta, and G. F. Schiefelbein, 1993, Ferrocyanide Safety Project, Task 3: Ferrocyanide Aging Studies - FY 1993 Annual Report, PNL-8888, Pacific Northwest Laboratory, Richland, Washington.

Lilga, M. A., E. V. Alderson, R. T. Hallen, M. O. Hogan, T. L. Hubler, G. L. Jones, D. J. Kowalski, M. R. Lumetta, G. F. Schiefelbein, and M. R. Telander, 1995, Ferrocyanide Safety Project: Ferrocyanide Aging Studies - FY 1995 Annual Report, PNL-10713, Pacific Northwest Laboratory, Richland, Washington.

Lilga, M. A., E. V. Alderson, R. T. Hallen, M. O. Hogan, T. L. Hubler, G. L. Jones, D. J. Kowalski, M. R. Lumetta, and M. R. Telander, 1996, Ferrocyanide Safety Project: Ferrocyanide Aging Studies - Final Report, PNL-11211, Pacific Northwest Laboratory, Richland, Washington.

McLaren, J. M., 1994a, Ferrocyanide Safety Program: Thermal Analysis of Ferrocyanide Tanks, Group I, WHC-EP-0729, Westinghouse Hanford Company, Richland, Washington.

McLaren, J. M., 1994b, Ferrocyanide Safety Program: Thermal Analysis of Ferrocyanide Watch List Tanks, Group II, WHC-EP-0794, Westinghouse Hanford Company, Richland, Washington. 
Meacham, J. E., 1995, Test Plan for Samples from Hanford Waste Tanks 241-BY-103, $B Y-104, B Y-105, B Y-106, B Y-108, B Y-110, T Y-103, U-105, U-107, U-108$, and U-109, WHC-SD-WM-TP-378, Rev. 0, Westinghouse Hanford Company, Richland, Washington.

Meacham, J. E., R. J. Cash, B. A. Pulsipher, and G. Chen, 1995a, Data Requirements for the Ferrocyanide Safety Issue Developed Through the Data Quality Objectives Process, WHC-SD-WM-DQO-007, Rev. 1, Westinghouse Hanford Company, Richland, Washington.

Meacham, J. E., R. J. Cash, and G. T. Dukelow, 1995b, Quarterly Report on Ferrocyanide Safety Program for the Period Ending September 30, 1995, WHC-EP-0474-18, Westinghouse Hanford Company, Richland, Washington.

Nguyen, D. M., 1989, Data Analysis of Conditions in Single-Shell Tanks Suspected of Containing Ferrocyanide, (internal memorandum 13314-89-025 to N. W. Kirch, March 2), Westinghouse Hanford Company, Richland, Washington.

O'Leary; H. R., 1994, /Transmittal of "Program Plan for Evaluation of the Ferrocyanide Waste Tank Safety issue at the Hanford Site, "DOE/RL-94-110], (letter to J. T. Conway, Chairman, Defense Nuclear Facilities Safety Board, December 2), U.S. Department of Energy, Washington, D.C.

Parra, S. A., 1994, Integrated Beta and Gamma Radiation Dose Calculations for Ferrocyanide Waste Tanks, WHC-SD-WM-TI-634, Rev. 0, Westinghouse Hanford Company, Richland, Washington.

Postma, A. K., J. E. Meacham, G. S. Barney, G. L. Borsheim, R. J. Cash, M. D. Crippen, D. R. Dickinson, J. M. Grigsby, D. W. Jeppson, M. Kummerer, J. M. McLaren, C. S. Simmons, and B. C. Simpson, 1994, Ferrocyanide Safety Program: Safety Criteria for Ferrocyanide Watch List Tanks, WHC-EP-0691, Westinghouse Hanford Company, Richland, Washington.

Public Law 101-510, Section 3137, 1990, Safety Measures for Waste Tanks at Hanford Nuclear Reservation, U.S. Congress, Washington, D.C. [Also referred to as the Wyden Amendment]

Rai, D., A. R. Felmy, S. C. Smith, and J. L. Ryan, 1994, Ferrocyanide Safety Project: Interim Report FY 1994 - Solubility of Ferrocyanide Compounds, PNL-10150, Pacific Northwest Laboratory, Richland, Washington.

Reich, F. R., T. V. Rebagay, D. A. Dodd, T. Lopez, and J. K. Watts, 1995, Summary of FY 1995 NIR Moisture Measurement Development and Implementation Activities, WHC-SD-WM-RPT-191, Rev. 0, Westinghouse Hanford Company, Richland, Washington. 
Scheele, R. D., 1993, Hanford Ferrocyanide Reactivity: Effects of Other Tank Constituents, PNL-SA-21452, Pacific Northwest Laboratory, Richland, Washington. Proceedings of the International High Level Radioactive Waste Management Conference '93, Las Vegas, NV.

Sheridan, T. R., 1994a, Closure of the Ferrocyanide Unreviewed Safety Question, (letter 9401180/94-SST-052 to A. L. Trego, President, Westinghouse Hanford Company, March 4), U.S. Department of Energy, Richland Operations Office, Richland, Washington.

Sheridan, T. R., 1994b, Approval to Remove Two Ferrocyanide Tanks, 241-BX-102 and 241-BX-106, from the Watch List, (letter 9406684/94-SST-205 to A. L. Trego, President, Westinghouse Hanford Company, November 17), U.S. Department of Energy, Richland Operations Office, Richland, Washington.

Sloat, R. J., 1954, TBP Plant Nickel Ferrocyanide Scavenging Flowsheet, HW-30399, General Electric Company, Richland, Washington.

Sloat, R. J. 1955, In-Farm Scavenging Operating Procedure and Control Data, HW-38955, General Electric Company, Richland, Washington.

Smith, D. A., 1986, Single-Shell Tank Isolation Safety Analysis Report, WHC-SD-WM-SAR-006, Rev. 2, Westinghouse Hanford Company, Richland, Washington.

Watkins, J. D., 1991, Report to United States Congress on Waste Tank Safety Issues at the Hanford Site, (letter to D. Quayle, President of the Senate, July 16), U.S. Department of Energy, Washington, D.C.

Watson, W. T., 1993, Proof of Principle Report for In-Tank Moisture Monitoring Using an Active Neutron Probe, WHC-EP-0695, Westinghouse Hanford Company, Richland, Washington.

WHC, 1990, Operating Specifications for Watch List Tanks, OSD-T-151-00030, Rev. 0, Westinghouse Hanford Company, Richland, Washington.

WHC, 1996, Operating Specifications for Watch List Tanks, OSD-T-151-00030, Rev. B-20, Westinghouse Hanford Company, Richland, Washington.

Wodrich, D. D., G. S. Barney, G. L. Borsheim, D. L. Becker, W. C. Carlos, M. J. Klem, R. E. Vandercook, and J. L. Ryan, 1992, Summary of Single-Shell Waste Tank Stability, WHC-EP-0347, Supplement, Westinghouse Hanford Company, Richland, Washington. 
WHC-SD-WM-SARR-038, Rev. 1

APPENDIX A

STATISTICAL ANALYSIS OF FERROCYANIDE AND NICKEL CONCENTRATIONS IN SAMPLED WASTE TANKS 
WHC-SD-WM-SARR-038, Rev. 1

This page intentionally left blank. 


\section{APPENDIX A}

\section{STATISTICAL ANALYSIS OF FERROCYANIDE AND NICKEL CONCENTRATIONS IN SAMPLED WASTE TANKS}

\section{A.1 INTRODUCTION AND SUMMARY}

This appendix gives the upper limit to a one-sided $95 \%$ confidence interval for the mean concentration (wt\%) for sodium nickel ferrocyanide and the lower limit to a one-sided $80 \%$ confidence interval on the mean concentration (wt \%) of nickel in several single-shell tanks. These confidence limits are computed from core (or auger) sample data from nine single-shell tanks, 241-BY-104, 241-BY-108, 241-BY-110, 241-C-108, 241-C-109, 241-C-111, 241-C-112, 241-T-107, and 241-TY-104.

An alternate statistical analysis based on the Weibull model is described in Appendix B.

The upper limit to the one-sided $95 \%$ confidence interval on the mean is less than $8 \mathrm{wt} \%$ sodium nickel ferrocyanide for all nine of these single-shell tanks. The lower limit to the one-sided $80 \%$ confidence interval on the mean is greater than $0.8 \mathrm{wt} \%$ nickel for six of the nine tanks. The lower limit was less than $0.8 \mathrm{wt} \%$ for tanks $241-\mathrm{BY}-110,241-\mathrm{T}-107$, and 241-TY-104.

\section{A.2 SOURCE AND DESCRIPTION OF THE OBSERVATIONS}

The observations used to construct the confidence limits are given in Tables A-1 through A-9. Some of the data were extracted from the LABCORE database (maintained by the 222-S Laboratory) and the TCD database (tank characterization database maintained by Pacific Northwest National Laboratory). For a specific tank, the data used to construct the confidence intervals were from the ferrocyanide portion of the waste. That is, not all of the cyanide and nickel data available from a tank were used in the computations. Cyanide assays were performed by an analysis developed at Pacific Northwest National Laboratory, specifically designed for the Hanford waste matrices (Bryan et al. 1994). Subsegments in Tables A-1 through A-9 are listed from top to bottom within each core.

The source of the observations and a brief description of the number of core samples and segments, by tank, are given below.

Tank 241-BY-104: The data were obtained from LABCORE. One core sample used in the computations (two segments were within the core), and the chemical analyses (when possible) were performed on quarter segments. The results were reported on a wet weight basis. The data are given in Table A-1. 
Tank 241-BY-108: The data were obtained from the tank characterization report by Baldwin (1996). Three core samples from two different risers were used, there were four segments per core, and the chemical analyses (when possible) were performed on quarter segments. The original results were reported on a wet weight basis. The data are given in Table A-2.

Tank 241-BY-110: The data were obtained from LABCORE. Data from three core samples from two different risers were used in the computations. There were two segments per core, and the chemical analyses (when possible) were performed on quarter segments. The original results were reported on a wet weight basis. The data are given in Table A-3.

Tank 241-C-108: The data were obtained from the tank characterization report by Sasaki (1995). Auger samples AUG-012 and AUG-014 were combined to form the top and bottom of one core sample, and AUG-015 was the other core sample. These "two" core samples were from different risers. The cyanide results were reported on half segments and were converted to dry weight basis. The nickel and percent water analyses were on quarter segments and reported on a wet weight basis. The top subsegment (A1) was not ferrocyanide waste. Results from this subsegment were not used in the statistical analysis of the data. The data are given in Table A-4.

Tank 241-C-109: The cyanide data were obtained from the laboratory report by Sprouse (1993). These results were reported on a dry weight basis. The nickel data, dry weight basis, were obtained from Scheele (1995). There were three core samples from three risers, each consisting of one segment. The chemical analyses were on a quarter segments. The data are given in Table A-5.

Tank 241-C-111: The data were obtained from the tank characterization report by Kelley (1995). There was only one auger sample. The chemical analyses were on quarter segments, and the results were reported on a wet weight basis. The data are given in Table A-6.

Tank 241-C-112: The cyanide data were obtained from the laboratory report by McKinley et al. (1992). These results were reported on a dry weight basis. The nickel data, dry weight basis, were obtained from Scheele (1995). There were two core samples from two risers, each consisting of two segments. The chemical analyses were on quarter segments. The data are given in Table A-7.

Tank 241-T-107: The data were obtained from the TCD and the statistical characterization report by Jensen et al. (1994). There were three core samples, with four segments per core. Some of the chemical analyses were done on half segments. The results were reported on a wet weight basis. The data are given in Table A-8.

Tank 241-TY-104: The data were obtained from LABCORE. There were two auger samples from different risers. The chemical analyses were completed on archive samples from quarter segments. The results were reported on a wet weight basis. 
Table A-1. Data from Tank 241-BY-104.

\begin{tabular}{|c|c|c|c|c|c|c|c|c|}
\hline \multirow[b]{2}{*}{ Wor } & \multirow[b]{2}{*}{ 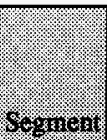 } & \multirow[b]{2}{*}{ 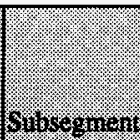 } & \multicolumn{2}{|c|}{ (otaride } & \multicolumn{2}{|c|}{$(0,8), 401)$} & \multicolumn{2}{|c|}{$\begin{array}{l}\text { Wret } \\
(\text { wrot }\end{array}$} \\
\hline & & & Singin & Yuln & S & $\mathrm{H}^{2}$ & Swrole & 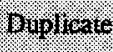 \\
\hline 116 & 7 & D & 69 & 58 & 11,400 & 12,000 & 26.81 & 24.36 \\
\hline 116 & 8 & A & 68 & 85 & 12,500 & 14,500 & 26.96 & 26.76 \\
\hline 116 & 8 & $\mathrm{D}$ & 20 & 2 & 5,560 & 5,730 & 33.59 & 35.26 \\
\hline
\end{tabular}

Table A-2. Data from Tank 241-BY-108.

\begin{tabular}{|c|c|c|c|c|c|c|c|c|}
\hline \multirow[b]{2}{*}{ fines } & \multirow[b]{2}{*}{$\left(x^{6}\right.$} & \multirow[b]{2}{*}{ 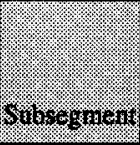 } & \multicolumn{2}{|c|}{ 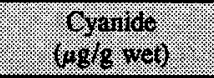 } & \multicolumn{2}{|c|}{ 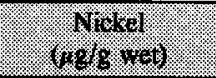 } & \multicolumn{2}{|c|}{$\begin{array}{l}\text { Water. } \\
(10 \%)\end{array}$} \\
\hline & & & Shmos & 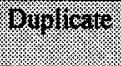 & 6 ining & Mylmirat & Samplot & Hupllogre \\
\hline $12 \mathrm{~A}$ & $98: 4$ & $\begin{array}{l}\text { A } \\
\text { B } \\
\text { C } \\
\text { D }\end{array}$ & $\begin{array}{l}1,740 \\
2,010 \\
1,850 \\
2,890\end{array}$ & $\begin{array}{l}1,900 \\
1,720 \\
1,880 \\
3,080\end{array}$ & $\begin{array}{c}14,900 \\
9,920 \\
5,650 \\
3,600\end{array}$ & $\begin{array}{c}14800 \\
9790 \\
5670 \\
3610\end{array}$ & $\begin{array}{l}28.9 \\
36.6 \\
35.4 \\
38.3 \\
36.5\end{array}$ & $\begin{array}{l}36.2 \\
36.7 \\
35.8 \\
39.8 \\
36.4\end{array}$ \\
\hline $12 \mathrm{~A}$ & $99: 4$ & $\begin{array}{l}\text { A } \\
\text { B } \\
\text { C } \\
\text { D }\end{array}$ & $\begin{array}{c}742 \\
1,660 \\
\text { NA } \\
1,150\end{array}$ & $\begin{array}{c}760 \\
1,650 \\
1,660 \\
\text { NA }\end{array}$ & $\begin{array}{c}14,670 \\
1,674 \\
6,710 \\
7,209\end{array}$ & $\begin{array}{l}\text { NA } \\
\text { NA } \\
\text { NA } \\
\text { NA }\end{array}$ & $\begin{array}{l}25.8 \\
35.3 \\
35.6 \\
40.6\end{array}$ & $\begin{array}{l}25.1 \\
35.9 \\
36.2 \\
44.0\end{array}$ \\
\hline 7 & $104: 5$ & $\begin{array}{l}\mathrm{B} \\
\mathrm{C} \\
\mathrm{D}\end{array}$ & $\begin{array}{c}99.9 \\
125 \\
98.4\end{array}$ & $\begin{array}{c}94.7 \\
117 \\
98.3\end{array}$ & $\begin{array}{c}12,200 \\
12,700 \\
7,810\end{array}$ & $\begin{array}{c}12100 \\
12900 \\
8340\end{array}$ & $\begin{array}{l}37.7 \\
35.5 \\
32.3\end{array}$ & $\begin{array}{l}35.6 \\
35.5 \\
34.6\end{array}$ \\
\hline
\end{tabular}


WHC-SD-WM-SARR-038, Rev. 1

Table A-3. Data from Tank 241-BY-110.

\begin{tabular}{|c|c|c|c|c|c|c|c|c|c|}
\hline \multirow[b]{2}{*}{ Riser } & \multirow[b]{2}{*}{ Cors } & \multirow[b]{2}{*}{ Seginen } & \multirow[b]{2}{*}{ Shinesegnem } & \multicolumn{2}{|c|}{ 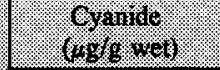 } & \multicolumn{2}{|c|}{ 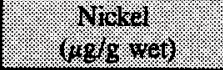 } & \multicolumn{2}{|c|}{$\begin{array}{l}\text { Water: } \\
(\mathrm{v}+8 \% \text { ) }\end{array}$} \\
\hline & & & & Sannple & Buylarate & Sinnfle & Punlarat & Samp te & Dyplyure \\
\hline 7 & 101 & 8 & $\mathrm{C}$ & 27 & 23 & 5,040 & 5,280 & 13.0 & 12.9 \\
\hline 7 & 101 & 8 & D & 9 & $<9$ & 619 & 670 & 5.2 & $0^{a}$ \\
\hline 7 & 101 & 9 & A & 15 & 28 & 9,410 & 8,570 & 25.3 & $0^{a}$ \\
\hline 7 & 101 & 9 & B & 35 & 47 & 15,200 & 12,900 & 25.4 & 27.2 \\
\hline 7 & 101 & 9 & $\mathrm{C}$ & 51 & 31 & $<350$ & $<401$ & 31.4 & 28.4 \\
\hline 7 & 101 & 9 & D & 40 & 59 & 13,100 & 8,450 & 8.6 & 15.9 \\
\hline 7 & 103 & 8 & D & 43 & 28 & 8,343 & 8,563 & 14.8 & 13.5 \\
\hline 7 & 103 & 9 & A & 800 & 577 & 4,505 & 4,552 & 32.8 & 33.7 \\
\hline 7 & 103 & 9 & B & 160 & 194 & 4,353 & 4,671 & 28.1 & 36.2 \\
\hline 7 & 103 & 9 & $\mathrm{C}$ & 20 & 13 & 13,547 & 10,908 & 28.6 & 31.4 \\
\hline 7 & 103 & 9 & D & 316 & 179 & 13,430 & 13,586 & 24.2 & 26.4 \\
\hline 7 & 107 & 8 & A & $<284$ & $<9$ & $<7$ & $<284$ & 30.8 & 34.7 \\
\hline 7 & 107 & 8 & B & 6,850 & 51 & 64 & 7,380 & 0.7 & 13.4 \\
\hline 7 & 107 & 9 & A & 11,200 & 43 & 39 & 11,200 & 29.7 & 34.0 \\
\hline 7 & 107 & 9 & B & 15,500 & 41 & 33 & 15,500 & 30.8 & 29.2 \\
\hline 7 & 107 & 9 & $\mathrm{C}$ & 10,500 & 33 & 31 & 11,500 & 30.0 & 31.2 \\
\hline 7 & 107 & 9 & D & 11,000 & 88 & 38 & 11,000 & 29.6 & 30.6 \\
\hline 4 & 113 & 7 & $\mathrm{~A}$ & 3,050 & 35 & 36 & 3,050 & 34.2 & 31.6 \\
\hline 4 & 113 & 7 & B & 2,290 & 14 & 23 & 2,100 & 38.6 & 36.8 \\
\hline 4 & 113 & 7 & $\mathrm{C}$ & 3,180 & 11 & 9 & 3,210 & 33.4 & 32.7 \\
\hline 4 & 113 & 7 & D & 1,430 & 8 & 6 & 2,370 & 38.3 & 31.7 \\
\hline 4 & 113 & 8 & A & $<358$ & 29 & 21 & $<388$ & 31.9 & 31.8 \\
\hline 4 & 113 & 8 & B & 2,300 & 55 & 31 & 2,300 & 32.4 & 31.0 \\
\hline 4 & 113 & 8 & C & 1,010 & 54 & 63 & 1,010 & 31.9 & 29.9 \\
\hline 4 & 113 & 8 & D & 2,560 & 5 & 7 & 2,560 & 10.7 & 10.0 \\
\hline
\end{tabular}

Note:

\footnotetext{
a The thermogravimetric scans do show weight losses for these samples (22 and 17 wt $\%$ for $8 D$ and 9 A, respectively), bowever, the weight loss cecurred at about $150{ }^{\circ} \mathrm{C}$. This indicates the samples may have waters of hydration, rather than free water.
} 
Table A-4. Data from tank 241-C-108.

\begin{tabular}{|c|c|c|c|c|c|c|c|}
\hline \multirow[b]{2}{*}{ An } & \multirow[b]{2}{*}{ Suibsegniner } & \multicolumn{2}{|c|}{ 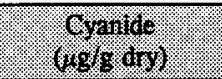 } & \multicolumn{2}{|c|}{$\begin{array}{l}\text { Wakel } \\
\text { colo wes) }\end{array}$} & \multicolumn{2}{|c|}{ Water: } \\
\hline & & Sampile & Puplacus & Saningle & Dupligene & Sample & Bupluares \\
\hline AUG-012 & $\begin{array}{l}\text { A1 } \\
\text { A2 }\end{array}$ & 961 & 926 & $\begin{array}{c}738 \\
1,830\end{array}$ & $\begin{array}{c}647 \\
1,480\end{array}$ & $\begin{array}{c}15.4 \\
9.9\end{array}$ & $\begin{array}{cc}3.0,6.0 \\
27.7, & 12.0\end{array}$ \\
\hline AUG-014 & $\begin{array}{l}\text { B } \\
\text { C }\end{array}$ & 8220 & 8400 & $\begin{array}{c}6,550 \\
18,100\end{array}$ & $\begin{array}{l}10,700 \\
19,200\end{array}$ & $\begin{array}{l}33.0 \\
45.8\end{array}$ & $\begin{array}{l}39.2 \\
46.3\end{array}$ \\
\hline AUG-015 & $\begin{array}{l}\text { A } \\
\text { B } \\
\text { C } \\
\text { D }\end{array}$ & $\begin{array}{l}2000 \\
2090\end{array}$ & $\begin{array}{l}2080 \\
2280\end{array}$ & $\begin{array}{c}9,360 \\
11,500 \\
11,000 \\
7,620\end{array}$ & $\begin{array}{c}9,500 \\
9,620 \\
10,300 \\
6,430\end{array}$ & $\begin{array}{l}51.9 \\
48.6 \\
53.0 \\
47.8\end{array}$ & $\begin{array}{l}46.8 \\
50.5 \\
52.4 \\
49.2\end{array}$ \\
\hline
\end{tabular}

Table A-5. Data from Tank 241-C-109.

\begin{tabular}{|c|c|c|c|c|c|c|}
\hline \multirow[b]{2}{*}{ Core } & \multirow[b]{2}{*}{ Sinibsegritur } & \multicolumn{2}{|c|}{ 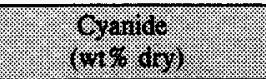 } & \multicolumn{2}{|c|}{ 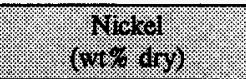 } & \multirow[b]{2}{*}{$\begin{array}{l}\text { Warer } \\
(w \& 5)\end{array}$} \\
\hline & & Siminge & 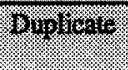 & 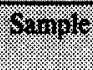 & byom (asate & \\
\hline 47 & $\begin{array}{l}\text { B } \\
\text { C } \\
\text { D }\end{array}$ & $\begin{array}{l}0.305 \\
0.449 \\
0.583\end{array}$ & $\begin{array}{l}0.303 \\
0.423 \\
0.582\end{array}$ & $\begin{array}{l}\text { NA } \\
\text { NA } \\
4.6\end{array}$ & $\begin{array}{l}\text { NA } \\
\text { NA } \\
\text { NA }\end{array}$ & NA \\
\hline 48 & $\begin{array}{l}\text { C } \\
\text { D }\end{array}$ & $\begin{array}{l}1.100 \\
0.860\end{array}$ & $\begin{array}{l}1.150 \\
0.871\end{array}$ & $\begin{array}{l}\text { NA } \\
\text { NA }\end{array}$ & $\begin{array}{l}\text { NA } \\
\text { NA }\end{array}$ & NA \\
\hline 49 & $\begin{array}{l}\text { B } \\
\text { C } \\
\text { D }\end{array}$ & $\begin{array}{l}0.350 \\
0.814 \\
0.561\end{array}$ & $\begin{array}{l}0.357 \\
0.802 \\
0.543\end{array}$ & $\begin{array}{l}0.8 \\
3.3 \\
3.2\end{array}$ & $\begin{array}{l}\text { NA } \\
\text { NA } \\
\text { NA }\end{array}$ & NA \\
\hline
\end{tabular}


WHC-SD-WM-SARR-038, Rev. 1

Table A-6. Data from Tank 241-C-111.

\begin{tabular}{|c|c|c|c|c|c|c|c|}
\hline \multirow[b]{2}{*}{ ilyes? } & \multirow[b]{2}{*}{ Sulbsegrinen } & \multicolumn{2}{|c|}{ 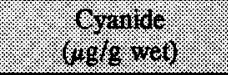 } & \multicolumn{2}{|c|}{$\begin{array}{l}\text { Nakel } \\
\text { (rogre net) }\end{array}$} & \multicolumn{2}{|c|}{$\begin{array}{l}\text { Water } \\
(\text { wotro) }\end{array}$} \\
\hline & & Shingle & Guplicate & Sample & Gupplicase & Sample & Buplizate \\
\hline AUG-016 & $\begin{array}{l}\text { B } \\
\text { C } \\
\text { D }\end{array}$ & $\begin{array}{c}93 \\
155 \\
107\end{array}$ & $\begin{array}{c}83 \\
151 \\
104\end{array}$ & $\begin{array}{l}1.55 \mathrm{E}+04 \\
2.24 \mathrm{E}+04 \\
1.15 \mathrm{E}+04\end{array}$ & $\begin{array}{l}2.08 E+04 \\
2.73 E+04 \\
1.14 E+04\end{array}$ & $\begin{array}{l}28.0 \\
44.7 \\
44.2\end{array}$ & $\begin{array}{l}22.8 \\
38.6 \\
44.2\end{array}$ \\
\hline
\end{tabular}

Table A-7. Data from Tank 241-C-112.

\begin{tabular}{|c|c|c|c|c|c|c|}
\hline \multirow[b]{2}{*}{ Gore. } & \multirow[b]{2}{*}{$\begin{array}{l}\text { Segnient: } \\
\text { Siltseznent }\end{array}$} & \multicolumn{2}{|c|}{$\begin{array}{l}\text { gyande } \\
\text { (witis) }\end{array}$} & \multicolumn{2}{|c|}{$\begin{array}{l}\text { Wirket } \\
(y+\% \text { dy) }\end{array}$} & \multirow[b]{2}{*}{ Water } \\
\hline & & Sample & 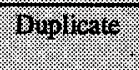 & Siniple & Wupherate & \\
\hline 34 & $\begin{array}{l}1 \mathrm{D} \\
2 \mathrm{~B} \\
2 \mathrm{C} \\
2 \mathrm{D}\end{array}$ & $\begin{array}{l}0.50 \\
0.43 \\
0.87 \\
0.77\end{array}$ & $\begin{array}{c}0.54,0.52 \\
0.43 \\
0.79 \\
0.74,0.73\end{array}$ & $\begin{array}{l}\text { NA } \\
3.8 \\
4.9 \\
3.2\end{array}$ & $\begin{array}{l}\text { NA } \\
\text { NA } \\
\text { NA } \\
\text { NA }\end{array}$ & NA \\
\hline 36 & $\begin{array}{l}1 \mathrm{D} \\
2 \mathrm{~A} \\
2 \mathrm{~B} \\
2 \mathrm{C} \\
2 \mathrm{D}\end{array}$ & $\begin{array}{l}0.73 \\
0.91 \\
0.75 \\
0.41 \\
0.57\end{array}$ & $\begin{array}{l}0.71 \\
0.94 \\
0.74 \\
0.39 \\
0.55\end{array}$ & $\begin{array}{l}5.1 \\
\text { NA } \\
\text { NA } \\
4.9 \\
0.2\end{array}$ & $\begin{array}{l}\text { NA } \\
\text { NA } \\
\text { NA } \\
\text { NA } \\
\text { NA }\end{array}$ & NA \\
\hline
\end{tabular}


WHC-SD-WM-SARR-038, Rev. 1

Table A-8. Data from Tank 241-T-107.

\begin{tabular}{|c|c|c|c|c|c|c|c|}
\hline \multirow[b]{2}{*}{ Oor } & \multirow[b]{2}{*}{ 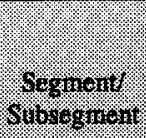 } & \multicolumn{2}{|c|}{ 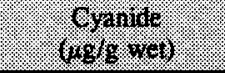 } & \multicolumn{2}{|c|}{ 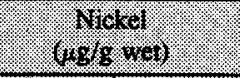 } & \multicolumn{2}{|c|}{$\left(\begin{array}{l}\text { water } \\
(y+1)\end{array}\right.$} \\
\hline & & Solmore & 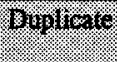 & Shmilo & B & 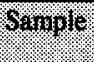 & Whalcose \\
\hline 50 & $\begin{array}{c}1 \mathrm{R} \\
2 \\
3 \\
4\end{array}$ & $\begin{array}{l}44.3 \\
62.5 \\
46.2 \\
\text { NA }\end{array}$ & $\begin{array}{l}52.6 \\
65.6 \\
39.2 \\
\text { NA }\end{array}$ & $\begin{array}{c}9,780 \\
3,470 \\
4,670 \\
\text { NA }\end{array}$ & $\begin{array}{c}8,070 \\
4,470 \\
4,480 \\
\text { NA }\end{array}$ & $\begin{array}{l}27.0 \\
45.8 \\
44.4 \\
57.2\end{array}$ & $\begin{array}{l}25.4 \\
40.3 \\
42.1 \\
59.0\end{array}$ \\
\hline 51 & $\begin{array}{c}2 \\
3 U \\
3 \mathrm{~L} \\
4 \mathrm{U} \\
4 \mathrm{~L}\end{array}$ & $\begin{array}{r}94.8 \\
110.0 \\
103.0 \\
94.2 \\
57.4\end{array}$ & $\begin{array}{c}95.7 \\
109.0 \\
102.0 \\
88.8 \\
57.2\end{array}$ & $\begin{array}{c}12,300 \\
1,700 \\
1,070 \\
983 \\
1,020\end{array}$ & $\begin{array}{c}11,900 \\
968 \\
637 \\
738 \\
849\end{array}$ & $\begin{array}{l}60.1 \\
59.4 \\
54.3 \\
54.8 \\
52.8\end{array}$ & $\begin{array}{l}58.5 \\
59.9 \\
54.2 \\
54.6 \\
53.4\end{array}$ \\
\hline 52 & $\begin{array}{c}1 \\
2 \\
3 \mathrm{U} \\
3 \mathrm{~L} \\
4\end{array}$ & $\begin{array}{c}31.5 \\
63.4 \\
50.5 \\
41.1 \\
\text { NA }\end{array}$ & $\begin{array}{l}30.5 \\
60.0 \\
53.7 \\
45.7 \\
\text { NA }\end{array}$ & $\begin{array}{c}\text { NA } \\
3,220 \\
3,440 \\
8,130 \\
\text { NA }\end{array}$ & $\begin{array}{c}\text { NA } \\
2,610 \\
1,060 \\
10,700 \\
\text { NA }\end{array}$ & $\begin{array}{l}15.2 \\
55.6 \\
54.6 \\
54.8 \\
59.3\end{array}$ & $\begin{array}{l}15.3 \\
55.4 \\
54.6 \\
49.7 \\
57.7\end{array}$ \\
\hline
\end{tabular}

Table A-9. Data from Tank 241-TY-104.

\begin{tabular}{|c|c|c|c|c|c|c|c|}
\hline \multirow[b]{2}{*}{ Muger } & \multirow[b]{2}{*}{ Sultivegnem } & \multicolumn{2}{|c|}{ 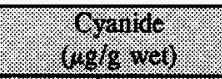 } & \multicolumn{2}{|c|}{ 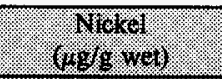 } & \multicolumn{2}{|c|}{$\begin{array}{l}\text { Water } \\
(17 \%)\end{array}$} \\
\hline & & Sampla & Dipluare & Srmpile & Dirplicatre & Siniple & Dopleater: \\
\hline AUG-008 & D & 130.0 & 143.0 & 2,530 & 2,520 & 48.1 & 47.15 \\
\hline $\begin{array}{l}\text { AUG-009 } \\
\text { AUG-009 }\end{array}$ & $\begin{array}{l}\text { C } \\
\text { D }\end{array}$ & $\begin{array}{l}138.0 \\
62.5\end{array}$ & $\begin{array}{l}136.0 \\
82.4\end{array}$ & $\begin{array}{l}3,660 \\
1,330\end{array}$ & $\begin{array}{l}2,980 \\
1,770\end{array}$ & $\begin{array}{l}37.9 \\
56.6\end{array}$ & $\begin{array}{l}37.3 \\
54.0\end{array}$ \\
\hline
\end{tabular}




\section{A.3 CONVERSION OF UNITS}

The units for most of the data given in Tables A-1 to A-9 are $\mu \mathrm{g} / \mathrm{g}$ wet. Before the statistical analysis was completed, the units were converted to weight percent (wt\%) dry. To make the conversion, the mean percent water was computed for each subsegment; $\mu \mathrm{g} / \mathrm{g}$ wet was converted to $\mu \mathrm{g} / \mathrm{g}$ dry using the equation

$$
\mu \mathrm{g} / \mathrm{g} \text { dry }=(\mu \mathrm{g} / \mathrm{g} \text { wet }) /[1-(\text { mean } \% \text { water }) / 100] \text {. }
$$

The $\mu \mathrm{g} / \mathrm{g}$ dry units were converted to weight percent (wt \%) by dividing by 10,000 .

The molecular weight of $\mathrm{Na}_{2} \mathrm{NiFe}(\mathrm{CN})_{6}$ is 316.64 and the molecular weight of $(\mathrm{CN})_{6}$ is 156.11. The total cyanide (CN) concentration was converted to sodium nickel ferrocyanide concentration by multiplying by 2.028 ; i.e.,

$$
\mathrm{Na}_{2} \mathrm{NiFe}(\mathrm{CN})_{6}=(316.64 / 156.11) *(\mathrm{CN})
$$

\section{A.4 STATISTICAL MODEL}

The most general form of the statistical model used to describes the structure of core (or auger) segment data is:

$\mathrm{y}_{\mathrm{ijk} \mathbf{m}}=\mu+\mathrm{R}_{\mathrm{i}}+\mathrm{C}_{\mathrm{ij}}+\mathrm{S}_{\mathrm{ijk}}+\mathrm{SS}_{\mathrm{ijkl}}+\mathrm{A}_{\mathrm{ijk} \mathbf{m}}, \mathrm{I}=1, \ldots \mathrm{a}, \mathrm{j}=1, \ldots \mathrm{b}_{\mathrm{i}}, \mathrm{k}=1, \ldots \mathrm{c}_{\mathrm{ij}}, \mathrm{l}=1, \ldots \mathrm{d}_{\mathrm{ijk}}$, $\mathrm{m}=1, \ldots \mathrm{n}_{\mathrm{j} \mathrm{kl} \mathrm{k}}$,

where

$\mathrm{y}_{\mathrm{ijklm}}=$ laboratory results from the $\mathrm{m}^{\text {th }}$ duplicate of the $\mathrm{I}^{\mathrm{th}}$ subsegment of the $\mathrm{k}^{\text {th }}$ segment of the $j^{\text {th }}$ core (or auger) of the $i^{\text {th }}$ riser

$\mu \quad=\quad$ the grand mean

$\mathrm{R}_{\mathrm{i}} \quad=\quad$ the effect of the $\mathrm{i}^{\text {th }}$ riser

$C_{i j}=$ the effect of the $j^{\text {th }}$ core from the $i^{\text {th }}$ riser

$\mathrm{S}_{\mathrm{j} \mathrm{j} \mathbf{k}} \quad=$ the effect of the $\mathrm{k}^{\text {th }}$ segment in the $\mathrm{j}^{\text {th }}$ core from the $\mathrm{i}^{\text {th }}$ riser

$\mathrm{SS}_{\mathrm{ijk}}=$ the effect of the $\mathrm{l}^{\text {th }}$ subsegment in the $\mathrm{k}^{\text {th }}$ segment in the $\mathrm{j}^{\text {th }}$ core from the $\mathrm{i}^{\text {th }}$ riser

$\mathrm{A}_{\mathrm{j} j \mathrm{~km}}=$ the analytical error associated with the $\mathrm{m}^{\text {th }}$ duplicate from the $\mathrm{I}^{\text {th }}$ subsegment in the $\mathrm{k}^{\text {th }}$ segment in the $\mathrm{j}^{\text {th }}$ core from the $\mathrm{i}^{\text {th }}$ riser 


$$
\begin{aligned}
& \text { a } \\
& b_{i}=\text { the number of risers } \\
& c_{i j} \quad=\text { the number of cores in the } i^{\text {th }} \text { riser } \\
& d_{i j k} \quad=\text { the number of subsegments in the } k^{\text {th }} \text { segment in the } j^{\text {th }} \text { core in the } i^{\text {th }} \text { riser } \\
& n_{i j k l} \quad=\quad \text { the number of analytical results in the } l^{\text {th }} \text { subsegment in the } k^{\text {th }} \text { segment in the }
\end{aligned}
$$

The variables $R_{i}, C_{i j}, S_{i j k}$, and $S S_{i j k l}$ are assumed to be random effects. It is assumed that $R_{i}$, $\mathrm{C}_{\mathrm{ij}}, \mathrm{S}_{\mathrm{ijk}}, \mathrm{SS}_{\mathrm{ijkl}}$, and $\mathrm{A}_{\mathrm{ijkm}}$ are uncorrelated and normally distributed with means zero and variances $\sigma^{2}(\mathrm{R}), \sigma^{2}(\mathrm{C}), \sigma^{2}(\mathrm{~S}), \sigma^{2}(\mathrm{SS})$, and $\sigma^{2}(\mathrm{~A})$, respectively. Estimates of $\sigma^{2}(\mathrm{R}), \sigma^{2}(\mathrm{C})$, $\sigma^{2}(\mathrm{~S}), \sigma^{2}(\mathrm{SS})$, and $\sigma^{2}(\mathrm{~A})$ were obtained using restricted maximum likelihood estimation (REML) techniques. This method applied to variance component estimation is described in Harville (1977).

Table A-10 gives the terms in the statistical models that were appropriate for the analysis of each set of data. An " $\mathrm{X}$ " in a cell indicates that the statistical model contained that particular effect. For instance, the model used to analyze the data from tank BY-110 consisted of $\mu$, $R_{i}, C_{i j}, S_{i j k}, S_{i j k l}$ and $A_{i j k l m}$. 
Table A-10. Effects in the Statistical Model for Each Tank.

\begin{tabular}{|c|c|c|c|c|c|c|}
\hline (2) & . & R. & ?. & S.1. & SS & $1, \sqrt{1}$ \\
\hline BY-104 & $x$ & & & $X$ & $\mathrm{X}$ & $X$ \\
\hline BY-108 & $X$ & $\mathrm{X}$ & $\mathrm{X}$ & & $\mathrm{X}$ & $X$ \\
\hline BY-110 & $X$ & $\mathrm{X}$ & $\mathrm{X}$ & $\mathrm{X}$ & $\mathrm{X}$ & $\mathrm{X}$ \\
\hline C-108 & $\mathrm{X}$ & & $\mathrm{X}$ & & $\mathrm{X}$ & $X$ \\
\hline C-109 & $X$ & & $\mathrm{X}$ & & $\mathrm{X}$ & $X$ \\
\hline C-111 & $\mathrm{X}$ & & & & $\mathrm{X}$ & $\mathrm{X}$ \\
\hline C-112 & $\mathrm{X}$ & & $\mathrm{X}$ & $X$ & $\mathrm{X}$ & $\mathrm{X}$ \\
\hline T-107 & $\mathrm{X}$ & & $\mathrm{X}$ & $\mathrm{X}$ & & $X$ \\
\hline TY-104 & $\mathrm{X}$ & & $\mathrm{X}$ & & $\mathrm{x}$ & $\mathrm{X}$ \\
\hline
\end{tabular}

\section{A.4.1 Confidence Intervals}

The upper limit (UL) of a one-sided $95 \%$ confidence interval for the mean $\mathrm{Na}_{2} \mathrm{NiFe}(\mathrm{CN})_{6}$ concentration, wt $\%$ dry is

$$
\mathrm{UL}=\hat{\mu}+\mathrm{t}_{(\mathrm{df}, 0.95)} * \hat{\sigma}_{\hat{\mu}},
$$

and the lower limit (LL) of a one-sided $80 \%$ confidence interval for the mean nickel, wt\% dry, is

$$
\mathrm{LL}=\hat{\mu}-\mathrm{t}_{\mathrm{df}, 0.80)} * \hat{\sigma}_{\hat{\mu}} .
$$

In these equations, $\hat{\mu}$ is the weighted mean of the analyte concentration, wt $\%$ dry, $\hat{\sigma}_{\hat{\mu}}$ is the standard deviation of the mean, and $\mathrm{t}_{\mathrm{df}, \gamma)}$ is a quantile from Student's $t$ distribution with $d f$ degrees of freedom and $\gamma$ confidence level $\left(\gamma=0.95\right.$ for $\mathrm{Na}_{2} \mathrm{NiFe}(\mathrm{CN})_{6}$ and $\gamma=0.80$ for nickel). 
The segment level data were converted from $\mu \mathrm{g} / \mathrm{g}$, wet weight basis, to $\mu \mathrm{g} / \mathrm{g}$, dry weight basis, by dividing by the mean segment moisture level. The variability in the moisture content has not been incorporated into the confidence intervals. This means that the upper and lower limits of the intervals are underestimated.

Table A-11 gives $\hat{\mu}$, df, $\hat{\sigma}_{\hat{\mu}}$ and the upper limits to the one-sided $95 \%$ confidence interval on the mean for $\mathrm{Na}_{2} \mathrm{NiFe}(\mathrm{CN})_{6}$. Table A-12 gives $\hat{\mu}$, df, $\hat{\sigma}_{\hat{\mu}}$ and the lower limits to the one-sided $80 \%$ confidence interval on the mean for nickel. The next few paragraphs describe how the weighted mean, standard deviation of the mean, and degrees of freedom were figured.

Mean $(\hat{\mu})$. To compute the overall mean for each tank, a weighted mean was calculated. The weighting was determined by the structure of the data, which is generally reflected by the effects in the statistical models. For example, the data for tank BY-110 are described using riser, core, segment, subsegment, and analytical effects in the statistical model. All of the analytical results within each subsegment are weighted equally; all of the subsegments within each segment are weighted equally; all of the segments within each core are weighted equally; and all of the cores within each riser are weighted equally.

Degrees of Freedom ( $d f$ ). The degrees of freedom for five of the tanks are the number of core samples (or auger samples) minus one; the $d f$ for tanks BY-108 and BY-110 are number of risers minus one; the $d f$ for tank BY-104 is the number of segments minus one; and the $d f$ for $\mathrm{C}-111$ is the number of sub-segments minus one.

Standard Deviation of the Mean $\left(\hat{\sigma}_{\hat{\mu}}\right)$. The estimates of $\sigma^{2}(\mathrm{R}), \sigma^{2}(\mathrm{C}), \sigma^{2}(\mathrm{~S}), \sigma^{2}(\mathrm{SS})$, and $\sigma^{2}($ A) were obtained using restricted maximum likelihood estimation (REML) techniques. The standard deviation of the mean, $\hat{\sigma}_{\hat{\mu}}$, is the square root of a linear combination of these variances. 
Table A-11. Summary Statistics for $\mathrm{Na}_{2} \mathrm{NiFe}(\mathrm{CN})_{6}$ Concentration.

\begin{tabular}{|c|c|c|c|c|}
\hline Why & 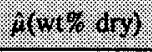 & 67 & 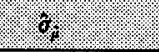 & $65 \%$ GL \\
\hline BY-104' & 0.0147 & 1 & 0.0054 & 0.0490 \\
\hline BY-108 & 0.2888 & 2 & 0.2549 & 1.8984 \\
\hline BY -110 & 0.0138 & 1 & 0.0132 & 0.0971 \\
\hline $\mathrm{C}-108$ & 0.6834 & 1 & 0.3387 & 2.8217 \\
\hline C-109 & 1.3569 & 2 & 0.3318 & 2.3258 \\
\hline C $-111^{\mathrm{a}}$ & 0.0389 & 2 & 0.0081 & 0.0627 \\
\hline C-112 & 1.3000 & 1 & 0.0100 & 2.0000 \\
\hline $\mathrm{T}-107$ & 0.0265 & 2 & 0.0085 & 0.0515 \\
\hline TY-104 & 0.0458 & 1 & 0.0069 & 0.0892 \\
\hline
\end{tabular}

Note:

a There was only one auger sample in the statistical analysis; therefore, these results are only for the auger sample, not the contents of the tank. 
Table A-12. Summary Statistics for Nickel Concentration.

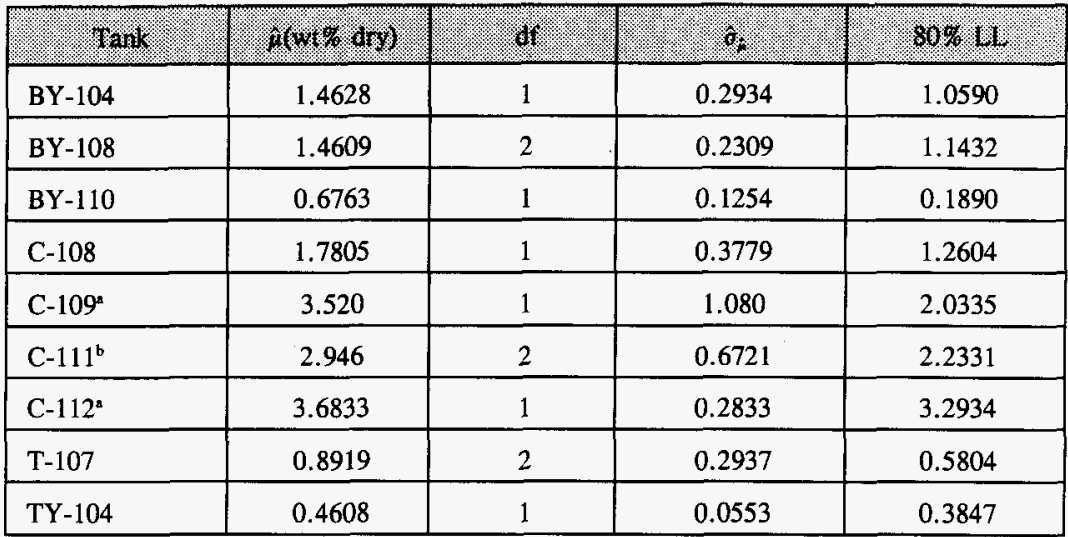

Note:

Limited nickel data were available for tanks C-109 and C-112. For this reason, the analytical data were averaged within each core and then an overall mean was computed for the tank by averaging the core means. The core means were also used to compute the standard deviation of the mean for the lower limits of the $80 \%$ confidence interval. Because there were only two core means for tanks C-109 and C-112, only one degree of freedom was used to compute the confidence interval.

b There was only one auger sample in the statistical analysis; therefore, these results are only for the auger sample, not the contents of the tank.

\section{A.5 CONCLUSIONS}

The upper limit to the one-sided $95 \%$ confidence interval on the mean is less than $8 \mathrm{wt} \%$ sodium nickel ferrocyanide for all nine of the single-shell tanks sampled. The lower limit to the one-sided $80 \%$ confidence interval on the mean is greater than $0.8 \mathrm{wt} \%$ nickel for six of the nine tanks. The lower limit is less than $0.8 \mathrm{wt} \%$ for tanks $241-\mathrm{BY}-110,241-\mathrm{T}-107$, and 241-TY-104. 


\section{A.6 APPENDIX A REFERENCES}

Baldwin, J. H., 1996, Tank Characterization Report for Single-Shell Tank 24I-B-108, WHC-SD-WM-ER-475, Rev. 0, Westinghouse Hanford Company, Richland, Washington.

Bryan, S. A., K. H. Pool, S. L. Bryan, B. D. Lerner, R. L. Sell, and L. M. P. Thomas, 1994, Ferrocyanide Safety Program: Cyanide Speciation Studies - FY 1994 Annual Report, PNL-10151, Pacific Northwest Laboratory, Richland, Washington.

Harville, D. A., 1977, "Maximum Likelihood Approaches to Variance Component Estimation and to Related Problems," Journal of the American Statistical Association, vol. 72, pp. 320-340.

Jensen, L., R. D. Cromar and S. R. Wilmarth, 1994, Statistical Characterization Report for Single-Shell Tank 24I-T-107, WHC-SD-WM-TI-645, Rev. 0, Westinghouse Hanford Company, Richland, Washington.

Kelley, S. E., 1995, Tank Characterization Report for Single-Shell Tank 241-C-111, WHC-SD-WM-ER-475, Rev. 0, Westinghouse Hanford Company, Richland, Washington.

McKinley, S. G., L. R. Greenwood, E. W. Hoppe, J. E. Tingey, and M. M. Urie, 1992, Single-Shell Tank Waste Characterization Project and Safety Analysis Project, Core 36 Data Report, Tank C-112, Pacific Northwest Laboratory.

Sasaki, L. M., 1995, Tank Characterization Report for Single-Shell Tank 241-C-108, WHC-SD-WM-ER-503, Rev. 0, Westinghouse Hanford Company, Richland, Washington.

Scheele, R. D., 1995, Ferrocyanide Safety Project: Comparison of Actual and Simulated Ferrocyanide Waste Properties, PNL-10175, Supplement 1, Pacific Northwest Laboratory, Richland Washington.

Sprouse, B. S., 1993, Single-Shell Tank Waste Characterization Project - Cores 47, 48, and 49 Data Report - Tank 241-C-109, WHC-SD-WM-DP-036, Addendum 2A, Rev. 0, Westinghouse Hanford Company, Richland, Washington. 
WHC-SD-WM-SARR-038, Rev. 1

\section{APPENDIX B}

STATISTICAL ANALYSIS OF FERROCYANIDE AND NICKEL CONCENTRATIONS IN SAMPLED WASTE TANKS - WEIBULL MODEL 
WHC-SD-WM-SARR-038, Rev. 1

This page intentionally left blank. 


\section{APPENDIX B}

\section{STATISTICAL ANALYSIS OF NICKEL FERROCYANIDE AND NICKEL CONCENTRATIONS IN SAMPLED WASTE TANKS - WEIBULL MODEL}

\section{B.1 INTRODUCTION AND OBJECTIVES}

Appendix B presents an alternative, based on the Weibull model, to the statistical analysis if sample data described in Appendix A. The sample data for 10 ferrocyanide waste tanks (C-108, C-109, C-111, C-112, BY-104, BY-106, BY-108, BY-110, T-107, and TY-104) are evaluated to address two questions relative to the ferrocyanide waste tank safety issue. The two questions are: (1) does the waste in a tank contain a sodium nickel ferrocyanide (fuel) concentration less than $8 \mathrm{wt} \% \mathrm{Na}_{2} \mathrm{NiFe}(\mathrm{CN})_{6}$; and (2) does the waste in a tank have a nickel concentration above $0.8 \mathrm{wt} \%$ ? These two questions are addressed by considering that the material concentrations in each waste volume in each tank can be represented by a model statistical distribution.

The objectives of the following evaluation are: (1) develop a parametric model concentration distribution for sodium nickel ferrocyanide and nickel from the waste tank sample data; (2) from the statistical distribution, calculate the probability of exceeding the decision limit of 8 wt $\% \mathrm{Na}_{2} \mathrm{NiFe}(\mathrm{CN})_{6}$ and $0.8 \mathrm{wt} \%$ nickel; and (3) determine, based on the ferrocyanide safety issue logic, if the waste tanks are in a safe configuration.

\section{B.2 RELATING SAMPLE DATA TO TANK DISTRIBUTION}

Figure B-1 illustrates schematically the concept of representing sample data from a waste tank for a specific material by a model probability density function. For visual purposes, the sample data are displayed on the left side of Figure B-1 in the form of a histogram for the specific analyte concentration. However, the histograms are not important factors in the analysis. Rather, the techniques identified below are used to model the sample data by a probability density function as illustrated on the right side of Figure B-1. The probability of exceeding a defined decision limit (DL) is the area under the probability distribution function beyond the decision limit.

The process assumes a model probability density function, and the appropriate parameters are estimated based on available sample data. Probability plots are constructed in order to determine whether or not the proposed model is reasonable. If the probability plot suggests the model is reasonable, then model parameters are determined by maximizing the likelihood function. Maximizing the likelihood function selects from an infinite family of probability density functions the probability density function that best represents the data. The modified Anderson-Darling goodness-of-fit test (Lawless 1982, Evans et al. 1989) is used to assure that the model is acceptable and cannot be rejected. The Anderson-Darling goodness-of-fit test is especially well suited for small sample sizes. 
WHC-SD-WM-SARR-038, Rev. 1

Figure B-1. Schematic of Sample Data Related to an Analyte Concentration Distribution via a Model Probability Density Function.
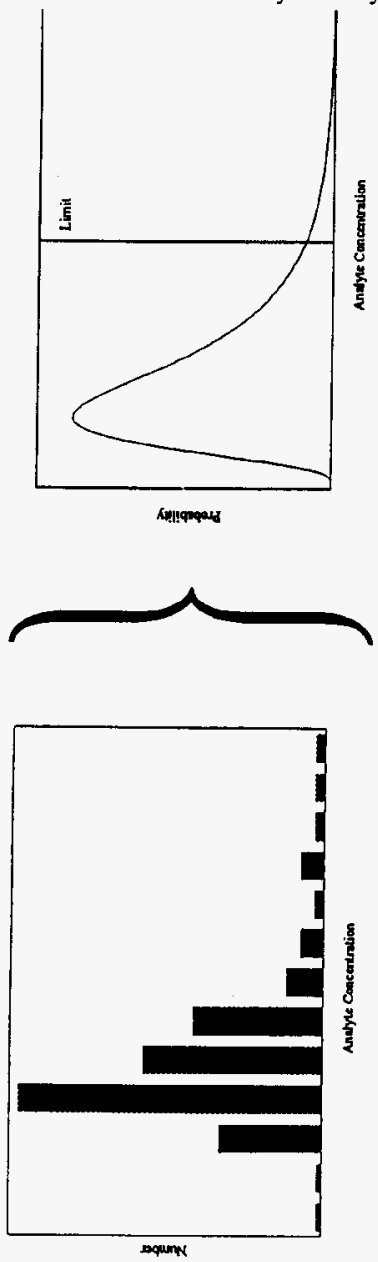
The model used is the two-parameter Weibull probability density function given by;

$$
f(x ; \eta, \beta)=\frac{\beta}{\eta}\left(\frac{x}{\eta}\right)^{\beta-1} e^{-\left(\frac{x}{\eta}\right)^{\beta}}
$$

The Weibull probability density function was chosen for two reasons. First, it is extremely flexible, and can represent many other commonly used probability density functions by changing the shape parameter $\beta$. For example, a Weibull probability density function can represent an exponentially decreasing probability density function, a lognormal probability density function, and a normal probability density function. Second, the cumulative distribution function is available in closed form, which greatly facilitates the calculations.

Single-sided $90 \%$ confidence bands are determined for the Weibull cumulative distribution function. The $90 \%$ confidence band means that if additional samples, of the same sample size, were repeatedly drawn from the true distribution, 90 out of 100 times the resulting cumulative distribution function would fall within the confidence band. The $90 \%$ confidence band can be directly related to the uncertainty in the probability of exceeding an action limit. However, the model statistical distribution derived by maximizing the likelihood function provides the best representation of the current sample data.

\section{B.3 SAMPLE ANALYSIS}

The waste contained in the four C Farm tanks (C-108, C-109, C-111, and C-112) has the highest concentration of sodium nickel ferrocyanide because of the addition of "In Farm" ferrocyanide to the waste. The waste contained in the BY Farm waste tanks (BY-104, BY-106, BY-108, and BY-110) is primarily U Plant waste and waste contained in the TY Farm waste tank (TY-104) is primarily T Plant waste. U Plant and T Plant wastes are expected to have a lower sodium nickel ferrocyanide concentration than the in-farm" waste.

All waste tanks analyzed contain non-complexed waste with the volume of sludge waste ranging from 40 to $173 \mathrm{kgal}$ (Hanlon 1996). In addition to the sludge waste, the four BY Farm waste tanks (BY-104, BY-106, BY-108, and BY-110) also contain saltcake waste ranging from 74 to $547 \mathrm{kgal}$ (Hanlon 1996). Table B-1 lists the waste volumes and corresponding thickness of sludge and saltcake waste (Hanlon 1996). 
Table B-1. Tank Volume and Thickness of Sludge and Saltcake Waste.

\begin{tabular}{|c|c|c|c|c|}
\hline 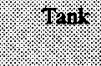 & 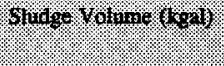 & 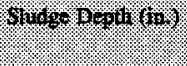 & 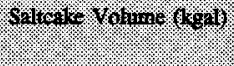 & Sylicalie Volune \\
\hline BY-104 & 40 & 22 & 366 & 133 \\
\hline BY-106 & 95 & 42 & 547 & 199 \\
\hline BY-108 & 154 & 63 & 74 & 27 \\
\hline BY-110 & 103 & 45 & 295 & 107 \\
\hline C-108 & 66 & 31 & 0 & 0 \\
\hline C-109 & 62 & 30 & 0 & 0 \\
\hline C-111 & 57 & 28 & 0 & 0 \\
\hline C-112 & 104 & 45 & 0 & 0 \\
\hline T-107 & 173 & 70 & 0 & 0 \\
\hline TY-104 & 46 & 23 & 0 & 0 \\
\hline
\end{tabular}

Waste tank sample data from safety screen results and tank characterization reports (Baldwin et al. 1996, Baldwin 1996, Benar 1996, Kelly 1995, Kristofzski 1995, Rice 1994, Rice 1995, Ryan and Amato 1995, Sasaki 1995, Schreiber 1995, Simpson et al. 1993a, Simpson et al. 1993b, Valenzuela and Jensen 1994) were used in the evaluation.

Probability plots were constructed for each waste type in each waste tank. For the BY Farm waste tanks, the sample data were bi-modal, or in some cases multi-modal, indicating that two or more waste regions, types or layers may exist. Descriptions of sample segments and subsegments provided in the safety screen results and tank characterization reports (Benar 1996, Baldwin et al. 1996, Baldwin 1996, Kristofzski 1995, Schreiber 1995) confirmed that waste regions or layers exist. Sample descriptions were used in conjunction with the model goodness-of-fit test to identify waste regions or layers that resulted in linear probability plots and passed the goodness-of-fit test.

For tank BY-104, the sample data were bi-modal, indicating that two different waste regions or layers exist. The bi-modal distribution was consistent with Hanlon results (Table B-1) and the 45-day safety screening results for tank BY-104 (Benar 1996) in that the first 63/4 core segments were identified as saltcake and the last $1 \frac{1 / 4}{4}$ core segments were identified as sludge. Figure B-2 depicts a two-layer model for tank BY-104. For a pictorial presentation, the layers have been extrapolated over the cross section of the waste tank by dashed lines. 
WHC-SD-WM-SARR-038, Rev. 1

Figure B-2. Tank BY-104 Two-Layer Waste Model.

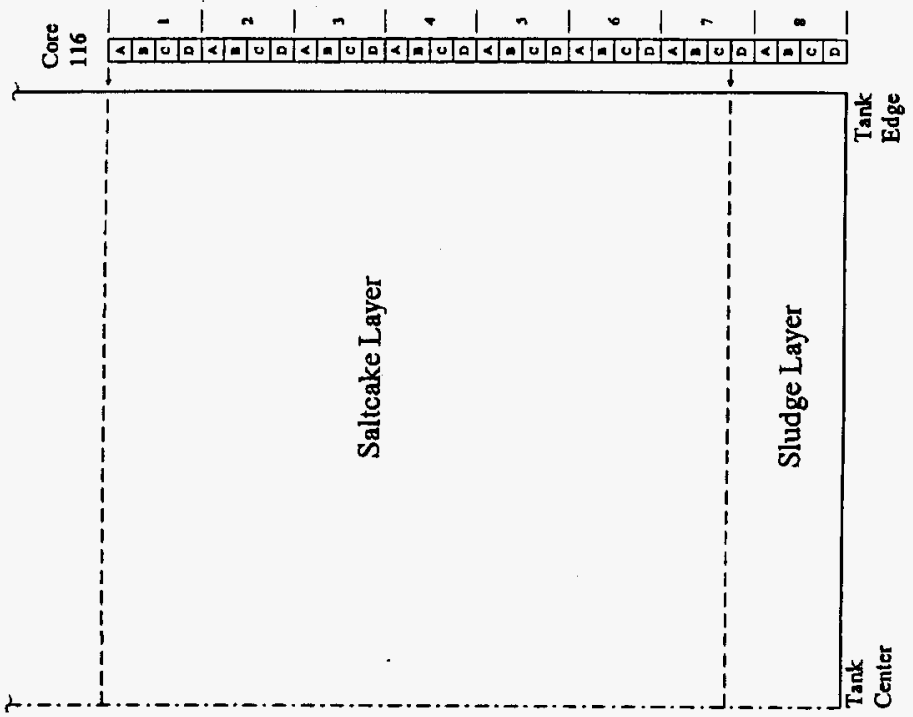


For tank BY-106, the sample data were also bi-modal, indicating that two different waste regions, types or layers exist. The bi-modal distribution was consistent with the Hanlon results (Table B-1) and the 90-day safety screening results for tank BY-106 (Kristofzski 1996) in that the first 12 core segments were identified as saltcake and the last core segment was identified as sludge. Figure B-3 depicts a two-layer model for tank BY-106. For a pictorial presentation, the layers have been extrapolated over the cross section of the waste tank by dashed lines.

For tank BY-108, the probability plots indicated the sample data were multi-modal, suggesting that several different waste regions and/or waste types exist. Descriptions of sample segments and sub-segments provided in the tank characterization report (Baldwin et al. 1996) confirmed that several waste regions exist. Various two- and three-layer models were attempted, none of which resulted in linear probability plots or passed the goodness-of-fit test. A successful four-region model was identified as shown in Figure B-4. Again, the layers have been extrapolated over the cross section of the waste tank by dashed lines.

For tank BY-110, the probability plots indicated the sample data were multi-modal, suggesting that several different waste regions and/or waste types exist. Descriptions of sample segments and sub-segments provided in the 45-day safety screening results for tank BY-110 (Schreiber 1995) confirmed that several waste regions exist. Various two- and threelayer models were attempted, none of which resulted in linear probability plots or passed the goodness-of-fit test. A successful four-region model was identified (Figure B-5). Again, the layers have been extrapolated over the cross section of the waste tank by dashed lines.

Waste stratification models exist for the four C Farm waste tanks. However, because the C Farm waste tanks only contain sludge, waste layering was not as distinct as that observed in the sludge layers in the BY Farm waste tanks. The sample data could be adequately represented by a single waste layer where the entire waste volume was assumed to be represented by a single probability density function. Similarly, tanks T-107 and TY-104 contain only sludge and could be adequately represented by a single waste layer where the entire waste volume was assumed to be represented by a single probability density function.

Probability plots were constructed for sodium nickel ferrocyanide and nickel in each waste region or layer. Initial estimates of the Weibull shape and position parameters were determined from the probability plots. The optimum values of the shape and position parameters were determined by maximizing the likelihood function. The modified Anderson-Darling goodness-of-fit test (Lawless 1982, Evans 1989) was used to confirm that the model could not be rejected for a given level of significance. Lastly, the probability of an analyte exceeding an action limit was calculated from the closed form solution of the Weibull cumulative distribution function. The single-sided $90 \%$ confidence band was determined for the Weibull cumulative distribution function using the method developed by Srinivasan and Wharton (1975). The resulting uncertainty in the probability of exceeding a decision limit, based on the $90 \%$ confidence band, is the value of the cumulative distribution function evaluated at the decision limit. 
WHC-SD-WM-SARR-038, Rev. 1

Figure B-3. Tank BY-106 Two-Layer Waste Model.

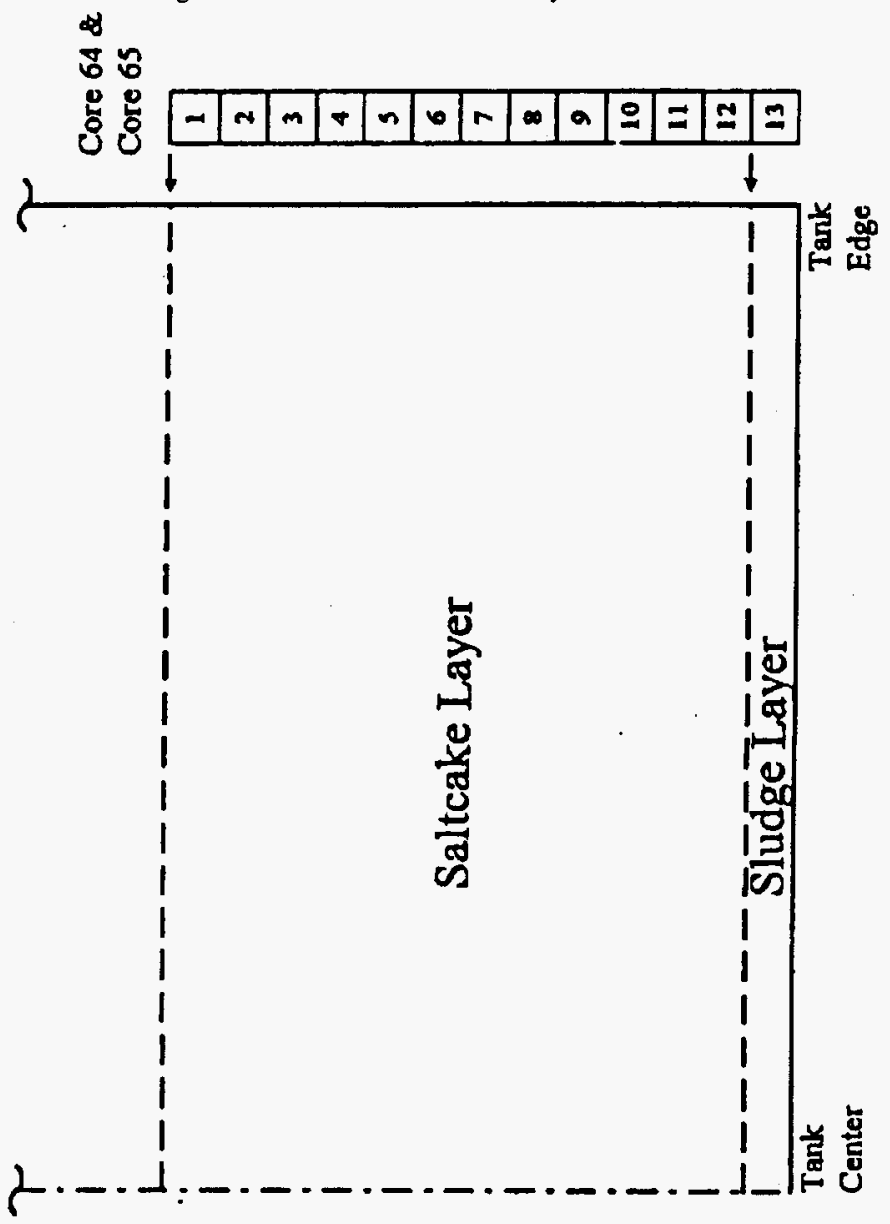


Figure B-4. Tank BY-108 Multi-Layer Waste Model.

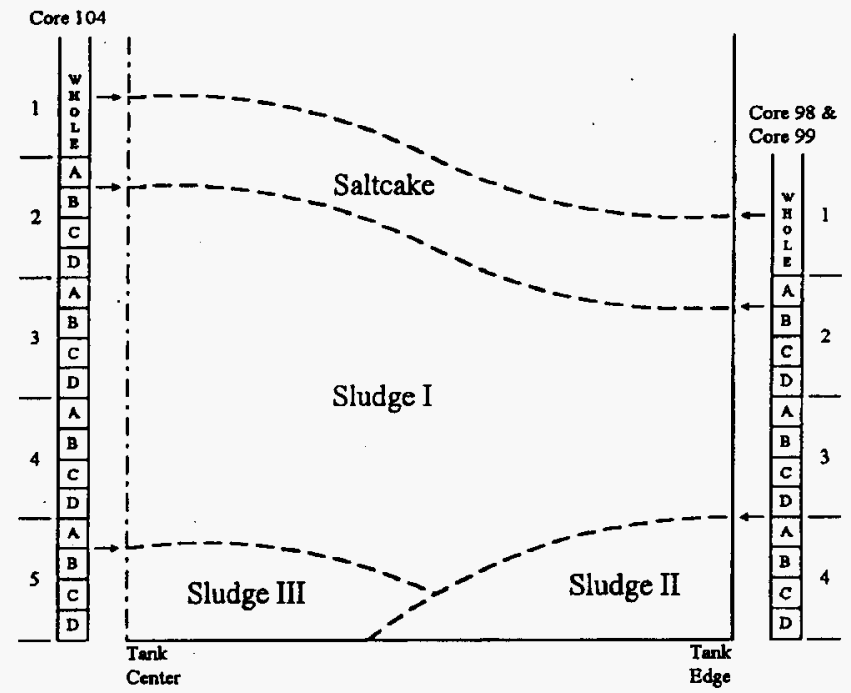


Figure B-5. Tank BY-110 Two-Layer Waste Model.

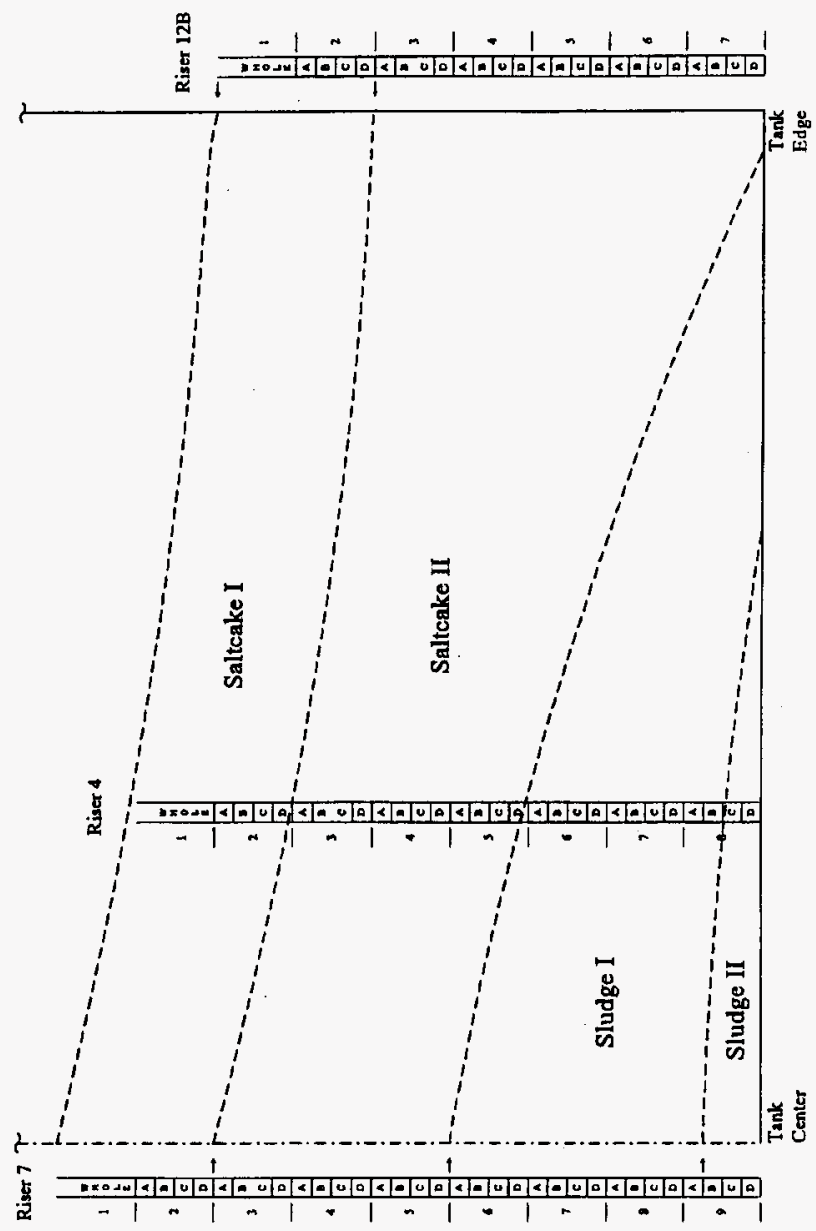




\section{B.4 RESULTS}

Tables B-2 through B-5 present a summary of the parametric modeling results. The summary tables provide the spread in the probability density function (as percentiles), the probability of exceeding a decision limit, the number of samples used to develop the model, and the upper and lower single-sided confidence band evaluated at the decision limit. Figure B-6 presents an example Weibull probability density function and a corresponding cumulative distribution function with the 1,50 , and 99 percentiles identified. The 1,50 , and 99 percentiles represent the probability of $0.01,0.50$, and 0.99 of not exceeding a specified analyte concentration. For example, in Figure B-5, there is a 0.01 probability of not exceeding $0.4 \mathrm{wt} \%$, a 0.50 probability of not exceeding $2.8 \mathrm{wt} \%$, and a 0.99 probability of not exceeding $6.5 \mathrm{wt} \%$.

As demonstrated in Figure B-6, the spread in the probability density function is indicated by the distribution percentiles. The attachment to this appendix provides the detailed data, analytical results, and graphs of the probability density function for each of the waste models.

Table B-2. Summary of Model Results for Sodium Nickel Ferrocyanide in C Farm Tanks.

\begin{tabular}{|c|c|c|c|c|c|c|}
\hline \multirow[b]{2}{*}{ Taris } & \multicolumn{3}{|c|}{ 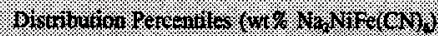 } & \multirow{2}{*}{ 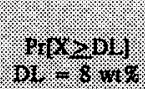 } & \multirow[b]{2}{*}{$\sqrt{1}$} & \multirow{2}{*}{ 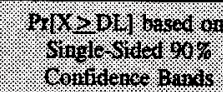 } \\
\hline & 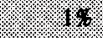 & $60 \%$ & $69 \%$ & & & \\
\hline C-108 & 0.034 & 0.621 & 2.294 & $<1 \times 10^{-6}$ & 5 & $<1 \times 10^{-6}-0.30$ \\
\hline C-109 & 0.237 & 1.247 & 2.621 & $<1 \times 10^{-6}$ & 8 & $<1 \times 10^{-6}-0.23$ \\
\hline $\mathrm{C}-111$ & 0.006 & 0.033 & 0.067 & $<1 \times 10^{-6}$ & 4 & $<1 \times 10^{-6}-0.30$ \\
\hline$C-112$ & 0.511 & 1.343 & 2.069 & $<1 \times 10^{-6}$ & 9 & $<1 \times 10^{-6}-0.21$ \\
\hline
\end{tabular}


WHC-SD-WM-SARR-038, Rev. 1

Figure B-6. Distribution Spread (as a percentile) for a Weibull Probability Density Function and a Cumulative Distribution Function.
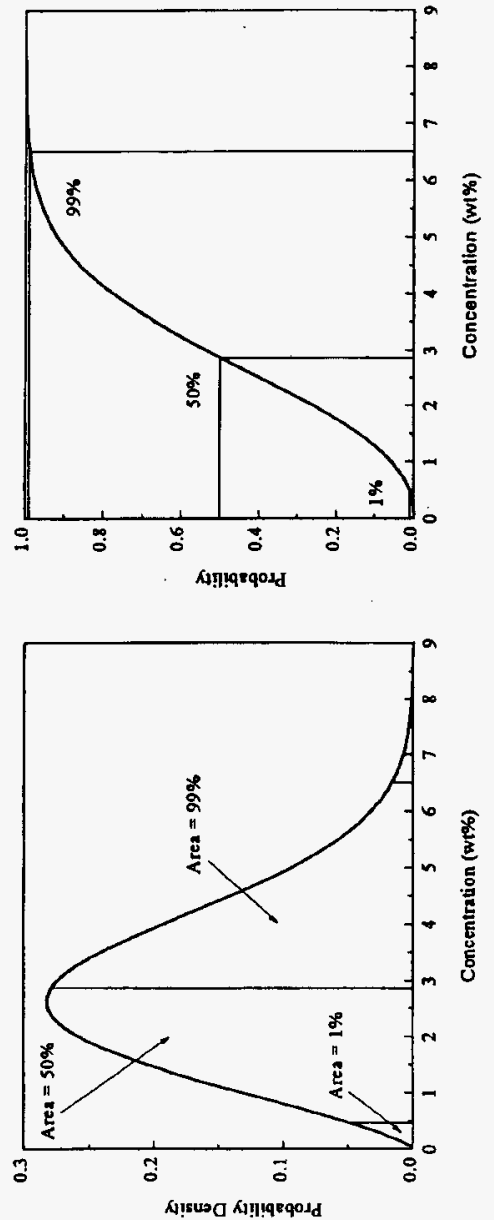

B-13 
Table B-3. Summary of Model Results for Nickel in C-Farm Tanks.

\begin{tabular}{|c|c|c|c|c|c|c|}
\hline \multirow[b]{2}{*}{ : } & \multicolumn{3}{|c|}{ 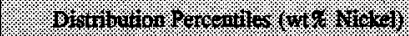 } & \multirow{2}{*}{$912=0.094 \%$} & \multirow[t]{2}{*}{ X } & \multirow{2}{*}{ 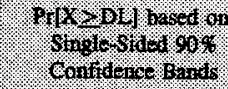 } \\
\hline & 18 & 40 & 89 & & & \\
\hline C-108 & 0.073 & 1.372 & 5.112 & 0.727 & 9 & $0.517-0.937$ \\
\hline C-109 & 0.453 & 2.857 & 6.507 & 0.964 & 4 & 0.664 - approaches 1.0 \\
\hline C-111 & 0.969 & 2.951 & 4.858 & 0.995 & 4 & 0.695 - approaches 1.0 \\
\hline C-112 & 1.154 & 3.623 & 6.044 & 0.997 & 6 & 0.717 - approaches 1.0 \\
\hline
\end{tabular}

Table B-4. Summary of Model Results for Sodium Nickel Ferrocyanide in BY, T and TY Farm Waste Tanks.

\begin{tabular}{|c|c|c|c|c|c|c|c|}
\hline \multirow[b]{2}{*}{ Thail } & \multirow[b]{2}{*}{ It groforor } & \multicolumn{3}{|c|}{ 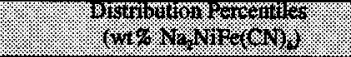 } & \multirow[b]{2}{*}{ 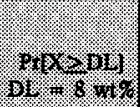 } & \multirow[b]{2}{*}{ 1X: } & \multirow{2}{*}{ 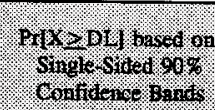 } \\
\hline & & 16 & 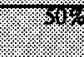 & 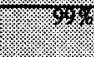 & & & \\
\hline \multirow[t]{2}{*}{ BY-104 } & Saltcake & 0.00005 & 0.0025 & 0.015 & $<1 \times 10^{\circ}$ & 6 & $<1 \times 10^{-0}-0.28$ \\
\hline & Sludge & 0.001 & 0.013 & 0.044 & $<1 \times 10^{-0}$ & 3 & $<1 \times 10^{-0}-0.35$ \\
\hline \multirow[t]{2}{*}{ BY-106 } & Saltcake & 0.0003 & 0.0058 & 0.0215 & $<1 \times 10^{\circ}$ & 15 & $<1 \times 10^{-5}-0.16$ \\
\hline & Sladge & Note (I) & & & & & \\
\hline \multirow[t]{4}{*}{ BY-108 } & Saltcake & 0.003 & 0.041 & 0.127 & $<1 \times 10^{-0}$ & 6 & $<1 \times 10^{-6}-0.28$ \\
\hline & Sludge I & 0.004 & 0.041 & 0.119 & $<1 \times 10^{-5}$ & 16 & $<1 \times 10^{\circ}-0.16$ \\
\hline & Sludge II & 0.131 & 0.541 & 1.022 & $<1 \times 10^{-6}$ & 8 & $<1 \times 10^{-6}-0.23$ \\
\hline & Sludge III & 0.022 & 0.033 & 0.041 & $<1 \times 10^{-5}$ & 3 & $<1 \times 10^{6}-0.35$ \\
\hline \multirow[t]{4}{*}{ BY-110 } & Saltcake I & Note (2) & & & & & \\
\hline & Saltcake II & $<1 \times 10^{-0}$ & 0.002 & 0.049 & $<1 \times 10^{-6}$ & 6 & $<1 \times 10^{-5}-0.28$ \\
\hline & Sludge I & $<1 \times 10^{-6}$ & 0.004 & 0.082 & $<1 \times 10^{6}$ & 27 & $<1 \times 10^{-6}-0.12$ \\
\hline & Sludge II & 0.005 & 0.017 & 0.084 & $<1 \times 10^{6}$ & 9 & $<1 \times 10^{-6}=0.21$ \\
\hline T-107 & Sludge & 0.003 & 0.026 & 0.064 & $<1 \times 10^{\circ}$ & 12 & $<1 \times 10^{-6}-0.18$ \\
\hline TY-104 & Sludge & 0.024 & 0.044 & 0.057 & $<1 \times 10^{-6}$ & 3 & $<1 \times 10^{-6}-0.35$ \\
\hline
\end{tabular}

Notes:

(1) Insufficient number of samples to develop model.

(2) No sample results reported. 
Table B-5. Summary of Model Results for Nickel in BY, T and TY Farm Waste Tanks.

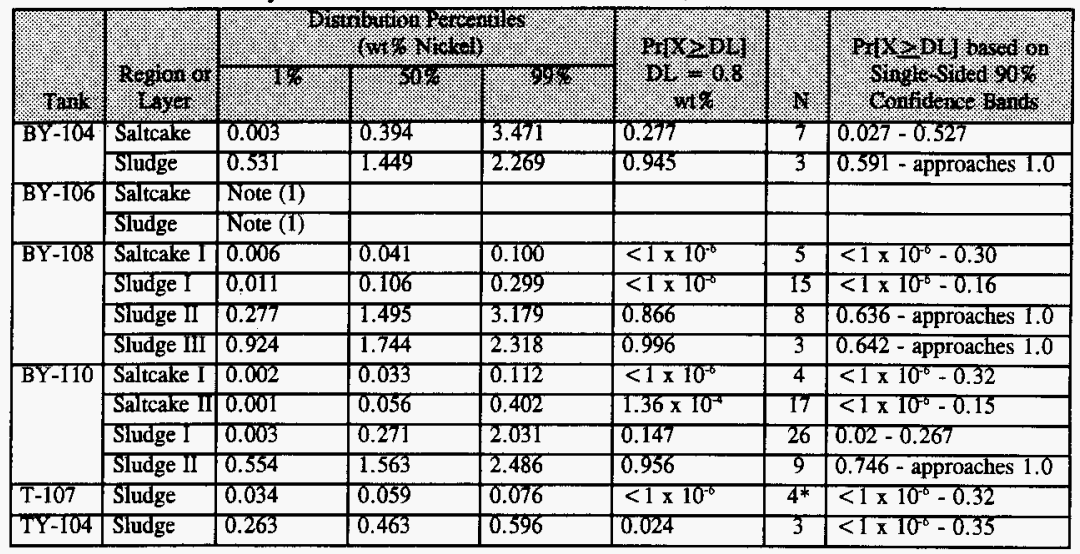

Notes:

(1) Insufficient number of samples to develop model.

* For analysis, sample results and duplicates were considered independent data points. 


\section{B.5 DISCUSSION}

Figures B-2 through B-5 identified waste regions or layers consisting of saltcake or sludge. This discussion of results will be limited to those regions or layers identified as sludge waste.

Estimates of the original ferrocyanide concentration (Brevick 1995a and Brevick 1995b) indicate that the four C Farm tanks (Table B-2) originally contained up to $22.6 \mathrm{wt} \%$ sodium nickel ferrocyanide, while the original ferrocyanide concentration for the other waste tanks (Table B-4) was approximately $8 \mathrm{wt} \%$ sodium nickel ferrocyanide. From Table B-2, there is a high probability (the order of 0.99 ) that the sodium nickel ferrocyanide concentration in the C Farm tanks is less than $2.5 \mathrm{wt} \%$. For the other waste tanks (Table B-4), there is a high probability (the order of 0.99 ) that the sodium nickel ferrocyanide concentration in the sludge is less than $1 \mathrm{wt} \%$. Also, the probability of the sodium nickel ferrocyanide concentration exceeding the decision limit $(8 \mathrm{wt} \%)$ is very small $\left(<1 \times 10^{-6}\right)$ for all waste tanks identified in Table B-2 and Table B-4. Thus, these results support the conclusion that the ferrocyanide in the waste tanks has aged, resulting in a much lower ferrocyanide concentration.

Based on original process flow sheets, the nickel concentration for a waste tank that originally contained sodium nickel ferrocyanide ranged from 0.87 to $4.8 \mathrm{wt} \%$ (Jeppson and Simpson 1994). From Table B-3, there is a high probability that the current nickel concentration in the waste is the same order of magnitude as the original nickel concentration for the four C Farm tanks. For the other waste tanks (Table B-5), there is a high probability that the current nickel concentration in the sludge is the same order of magnitude as the original nickel concentration, with three exceptions. For tanks T-107, TY-104 and the region of BY-108 identified as "Sludge I," the data suggest that the current nickel concentration is less than expected. Excluding these three exceptions, the nickel concentration has remained nearly the same, supporting the conclusion that these tanks did receive ferrocyanide waste.

\section{B.6 CONCLUSIONS}

The evaluation developed a statistical model for 10 ferrocyanide waste tanks (C-108, C-109, C-111, C-112, BY-104, BY-106, BY-108, BY-110, T-107, and TY-104) for sodium nickel ferrocyanide and nickel based on the waste tank sample data. The statistical distribution was used to calculate the probability of exceeding a sodium nickel ferrocyanide concentration of 8 $\mathrm{wt} \%$ and a nickel concentration of $0.8 \mathrm{wt} \%$.

The analysis results support the following conclusions:

(1) There is a relatively large probability that the present nickel concentration in the waste is the same order of magnitude as the original nickel concentration, and is above $0.8 \mathrm{wt} \%$. The relatively large nickel concentration provides strong indication that the wastes that were evaluated did contain sodium nickel ferrocyanide waste. 
(2) For all tanks analyzed there is a large probability (approaching 1) that the sodium nickel ferrocyanide concentration in the waste is less than $8 \mathrm{wt} \%$. The results support the assumption that the ferrocyanide has aged with a high probability that the present concentration of sodium nickel ferrocyanide is far less than the concentration present in the original ferrocyanide process.

Thus, it is concluded that the waste tanks are in a safe configuration, in that the ferrocyanide has aged, and there is a high probability that the sodium nickel ferrocyanide concentration is less than $8 \mathrm{wt} \%$.

\section{B.7 APPENDIX B REFERENCES}

Baldwin, J. H., R. J. Cash, W. I. Winters, L. Amato, and T. Tran, 1996, Tank Characterization Report for Single-Shell Tank 241-BY-108, WHC-SD-WM-ER-533, Rev. 0, Westinghouse Hanford Company, Richland, Washington.

Baldwin, J. H., 1996, Revised Final Report for Tank 241-BY-108, Rotary Samples Core 98 and Core 104, WHC-SD-WM-DP-145, Rev. 1A, Westinghouse Hanford Company, Richland, Washington.

Benar, C. J., 1996, 45-Day Safety Screening Results for Tank 241-BY-104, Rotary Mode [in Push Mode] Cores 116 and 117, WHC-SD-WM-DP-164, Rev. 0, Westinghouse Hanford Company, Richland, Washington.

Brevick, C. H., 1995a, Historical Tank Contents Estimates for the Northeast Quadrant of the Hanford 200 East Areas, WHC-SD-WM-ER-349, Rev. 0A, Westinghouse Hanford Company, Richland, Washington.

Brevick, C. H., 1995b, Historical Tank Contents Estimates for the Northeast Quadrant of the Hanford 200 West Areas, WHC-SD-WM-ER-349, Rev. 0A, Westinghouse Hanford Company, Richland, Washington.

Evans, J. W., R. A. Johnson, and D. W. Green, 1989, Two- and Three-Parameter Weibull Goodness-of-Fit Tests, Research Paper FPL-RP-493, U. S. Department of Agriculture, Forest Service, Forest Products Laboratory, Madison, Wisconsin.

Hanlon, B. M., 1996, Waste Tank Summary Report for Month Ending January 31, 1996, WHC-EP-0182-94, Westinghouse Hanford Company, Richland, Washington.

Jeppson, D. W., and B. C. Simpson, 1994, Characterization and Reaction Behavior of Ferrocyanide Simulants of Hanford Site High-Level Ferrocyanide Waste, WHC-SA-2190-FP, Westinghouse Hanford Company, Richland, Washington. 
Kelly, S. E., 1995, Tank Characterization Report for Single-Shell Tank 241-C-111, WHC-SD-WM-ER-475, Rev. 0-B, Westinghouse Hanford Company, Richland, Washington.

Kristofzski, J. G., 1995, 90-Day Safety Screen Results for Tank 241-BY-106, Rotary Mode, Cores 64 and 65, WHC-SD-WM-DP-103, Rev. 1, Westinghouse Hanford Company, Richland, Washington.

Lawless, J. F., 1982, Statistical Models and Methods for Lifetime Data, Chapter 9, Section 9.1.1, Tests Based on the EDF, John Wiley and Sons, New York, NY.

Rice, A. D., 1994, 216-Day Report for Tank 241-C-111, Cores 58 and 59, WHC-SD-WM-DP-079, Rev. 0, Westinghouse Hanford Company, Richland, Washington.

Rice, A. D., 1995, 60-Day Safety Screen Results and Final Report for Tank 241-C-111, Auger Samples 95-AUG-002, 95-AUG-003, 95-AUG-016, and 95-AUG-017, WHC-SD-WM-DP-114, Rev. 0, Westinghouse Hanford Company, Richland, Washington.

Ryan, G. W., and L. C. Amato [LATA], 1995, Tank Characterization Report for Single-Shell Tank 241-TY-104, WHC-SD-WM-ER-481, Rev. 0, Westinghouse Hanford Company, Richland, Washington.

Sasaki, L. M., 1995, Tank Characterization Report for Single Shell Tank 24I-C-108, WHC-SD-WM-ER-503, Rev. 0, Westinghouse Hanford Company, Richland, Washington.

Schreiber, R. D., 1995, 45-Day Safety Screening Results for Tank 241-BY-110, Rotary Mode Cores 92, 95, 96, 101, 103, 106, 107, 109, and 113, WHC-SD-WM-DP-153, Rev. 0, Westinghouse Hanford Company, Richland, Washington.

Simpson, B. C., G. L. Borsheim, and L. Jensen, 1993a, Tank Characterization Data Report: Tank 241-C-112, WHC-EP-0640, Rev. 1, Westinghouse Hanford Company, Richland, Washington.

Simpson, B. C., G. L. Borsheim, and L. Jensen, 1993b, Tank Characterization Report: Tank 241-C-109, WHC-EP-0668, Westinghouse Hanford Company, Richland, Washington.

Srinivasan, R., and R. M. Wharton, 1975, Confidence Bands for the Weibull Distribution, Technometrics, Vol. 17, No. 3, August. 
WHC-SD-WM-SARR-038, Rev. 1

Valenzuela, B. D., and L. Jensen, 1994, Tank Characterization Report for Single-Shell Tank 241-T-107, WHC-SD-WM-ER-382, Rev. 0A, Westinghouse Hanford Company, Richland, Washington. 
WHC-SD-WM-SARR-038, Rev. 1

This page intentionally left blank. 
WHC-SD-WM-SARR-038, Rev. 1

\begin{abstract}
APPENDIX C
PROCESS AND TEMPERATURE HISTORIES FOR THE FERROCYANIDE WATCH LIST TANKS
\end{abstract}

C-1 
WHC-SD-WM-SARR-038, Rev. 1

This page intentionally left blank.

C-2 


\section{APPENDIX C \\ PROCESS AND TEMPERATURE HISTORIES FOR THE FERROCYANIDE WATCH LIST TANKS}

This appendix reviews the temperature and process histories that have affected the rate of ferrocyanide aging in the Watch List tanks. Where available, temperature profiles in the ferrocyanide sludge layers are provided for the individual tanks.

\section{C.1 BY TANK FARM HISTORY}

The single-shell tanks in the BY Tank Farm (12 total) were constructed at the Hanford Site during 1948 and 1949 (Brevick et al. 1994a). The BY tanks are approximately $23 \mathrm{~m} \mathrm{(75} \mathrm{ft)}$

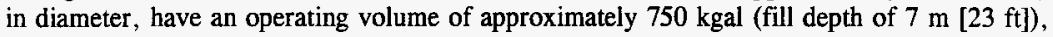
and are covered with approximately $2.5 \mathrm{~m}(8 \mathrm{ft})$ of overburden.

The BY tanks were initially used to store several different waste types. B Plant metal wastes were originally stored in tanks BY-101 through BY-106 after the BX Tank Farm was full. Tanks BY-107 through BY-110 received B Plant first-cycle waste and U Plant waste. Tanks BY-111 and BY-112 were used to store metal waste for a short time.

From 1954 to 1957 , the BY tanks were part of the ferrocyanide waste scavenging campaign, which was driven by the need to create additional waste tank storage space without constructing new tanks. During the ferrocyanide scavenging campaign, tank BY-112 received a direct transfer from $U$ Plant. Tanks BY-111 and BY-103 received ferrocyanide wastes from other BY tank transfers. Tanks BY-108, BY-107, BY-106, and BY-110 were used as primary settling tanks for ferrocyanide scavenged waste, and tanks BY-105 and BY-104 were used as settling tanks for accumulated scavenged sludge. According to historical records, the ferrocyanide waste content in any of these BY tanks never exceeded 8.3 wt\% (Postma et al. 1994).

\section{C.1.1 In-Tank Solidification}

In the late 1960s, after the ferrocyanide scavenging campaign was completed, plans for an in-tank solidification (ITS) program were initiated for the BY Farm tanks (Godfrey and Smith 1968). The objective was to produce more tank space without constructing new tanks. According to archive records, solidification of tank supernatant waste into saltcake by the ITS program offered another significant advantage, in addition to freeing up a large volume of existing storage space. Crystallizing the supernatant and driving off the excess water formed a solid waste form that assured a higher degree of waste containment in tanks already assumed to be leaking (Caudill 1965). As a result of the ITS program, the waste temperatures in the BY tanks were elevated, using electrical heaters, to levels that greatly enhanced the aging of the ferrocyanide wastes put into the tanks earlier. 
The original plan was to operate three ITS systems (ITS-1, ITS-2 and ITS-3). However, based on the success of ITS-1 and ITS-2, ITS-3 was not implemented. The ITS-1 operated for about seven years, starting in 1965, and only involved a couple of the BY Farm tanks. The initial ITS-1 system was installed in tank BY-101 where it was successfully tested and operated, producing approximately $365 \mathrm{kgal}$ of saltcake (Godfrey and Smith 1968). The ITS-1 hardware was then moved to BY-102 where it produced about $325 \mathrm{kgal}$ of saltcake. In 1971, ITS-1 was modified and used as a cooler for hot waste from ITS-2. The ITS-2 directly involved the remaining 10 BY Farm tanks and operated from about 1971 until 1975 , when it was shut down. The heat from the ITS-1 and ITS-2 process produced the high waste temperatures that resulted in the accelerated aging of the BY Farm ferrocyanide wastes. The increased density of heat producing isotopes, principally cesium, would have assisted the heating process, but would not have been significantly enough in the BY Farm tanks to achieve the temperatures needed for waste solidification.

\section{C.1.2 In-Tank Solidification Unit 1}

The ITS-1 unit bubbled heated air from a 1,400-kW heater (located on the surface) through the supernatant (Shefcik 1964) and collected and condensed water-laden air from the tank headspace. The heater produced air at $1,200^{\circ} \mathrm{F}$. Because of heat losses between the piping and the waste, air injected into the waste was about $700^{\circ} \mathrm{F}$. According to one reference (J.J. Shefick),

"Initially the waste temperature will be about $170^{\circ} \mathrm{F}$ and will increase as the salt concentration increases."

This same reference indicates a minimum temperature as a condition of ITS operation.

"A dip sample taken from the waste tank shall become a salt cake at a temperature of not less than $120^{\circ} \mathrm{F}$."

Thus, the ITS temperature ranged from a minimum of greater than $120^{\circ} \mathrm{F}$ to a maximum of $270{ }^{\circ} \mathrm{F}$ as the salt concentration increased during the loss of water. The large volume of the tank provided good temperature control and only small temperature variations as waste was transferred between tanks. The sparging action of the heated inlet air provided waste mixing and stirring necessary to prevent formation of a saltcake crust (that would inhibit the exchange of moisture to the headspace), and it also enhanced removal of moisture from the waste.

A special air exhauster system was added to the ITS-1 tanks. This system pumped hot air from the tank headspace through a filtered cooling system that removed entrained particles and moisture. The condensate was then pumped to a waste crib for disposal.

Instrument assemblies were installed in the tank to measure liquid level, specific gravity, and waste temperature. When the liquid level in the tank dropped, additional waste was added to maintain an operational liquid inventory in the ITS-1 tank. Concentration and solidification 
(crystallization) of the waste were completed in the tank containing the ITS-1 unit (first tank BY-101 and then tank BY-102) (McKnight 1969). The major ITS-1 feed tank was BY-105. In 1971, the ITS-1 unit was shut down and tank BY-102 was used as part of the cooling path for the ITS-2 unit that had been installed in tank BY-112.

\section{C.1.3 In-Tank Solidification Unit 2}

The ITS-2 system contained several design and operational features that were different from the ITS-1 system. However, the same principles of evaporation of water by raising the waste temperature followed by salt cake solidification through cooling applied which required the same temperature limits as with ITS-1. The ITS-2 electrical heater unit in tank BY-112 heated the waste liquids, which were then pumped or cycled through a number of additional BY tanks, each with a progressively decreasing temperature. One historical ITS-2 system reference indicates:

"These concentrates are being circulated through 4 tanks in the 241-BY Farm (107, 108,110 , and 111) for cooling, solids precipitation, and accumulation.

This reference further states:

"Four tanks (103, 104, 105 and 106) in the 241-BY Farm were selected for incorporation because of their close proximity to the existing bottoms circulating tanks, thus minimizing expenditure."

The waste, circulating through a string of tanks, was progressively cooled, producing a saltcake precipitate. An early hazards analysis indicated that in order to assure structural qualities of the tanks, the maximum allowed temperature increase in a tank would be $3{ }^{\circ} \mathrm{F}$ per day, with a maximum tank temperature not to exceed $300^{\circ} \mathrm{F}$ (Backman et al. 1965). The typical ITS system design would use six tanks, circulating an average of about 40 $\mathrm{gal} / \mathrm{min}$ of salt solution, producing a temperature of about $130^{\circ} \mathrm{F}$ in the last tank. The last tank (tank BY-109) acted as the feed tank for the ITS-2 unit (Barnes 1972). Fresh liquid feed was blended with the recycle material in the last tank so that the feed to the ITS-2 system tank would be in the range of 120 to $130^{\circ} \mathrm{F}$.

The ITS-2 unit in tank BY-112 used a 4,000-kW electrical heater (about a 10-ft-long assembly of cal rod heaters) that was directly immersed in the tank liquid (McKnight 1969). An integral pump moved liquid over the heater surfaces to increase the heat transfer from the heating elements. In addition, three air lift circulators were installed in risers in each of the ITS-2 BY tanks, including BY-112. Mixing was essential to prevent a saltcake crust from forming on the waste surface, inhibiting moisture exchange with the headspace air. The circulators also greatly enhanced scavenging of moisture from the hot liquid concentrate. The thermal design goal for the ITS- 2 unit was an evaporation rate of $20 \mathrm{gal} / \mathrm{min}$ (Caudill 1965 ), with a waste concentration factor of four to seven. This design was to have produced an estimated 150,000 gal per month of waste saltcake. 
Based on the cooling performance of the tanks and the resulting accumulation of saltcake, several different paths through the BY tanks were used, as indicated in Figure C- 1 . The liquid cycling and the order of the tanks in the cycling is important in that it helps establish waste temperatures in tanks where no data currently have been found. Prior to 1971, ITS-2 primarily used tanks BY-111, BY-110, BY-107, BY-108, and BY-109 in the liquid cycle. Tank BY-109 was the last tank in the loop and was used as the feed tank for the ITS in tank BY-112. Also prior to 1971 , tank BY-109 also received liquids from other tanks, such as BX-103.

Archived documents indicate that tank BY-111 initially was the first tank that received hot liquids from the ITS-2 in tank BY-112 (Caudill 1965). Archived design documentation also describes the heated transfer piping, pump pits, air lift circulators, utility services and exhauster (water and particulate scavenging) equipment that was later provided for tanks BY $-103,-104,-105$, and -106 so they also could be used to circulate concentrated, hot liquids from the ITS-2 system (McKnight 1969). Thus, BY-112 would have been the tank with the highest waste temperatures and BY-109 with the lowest waste temperatures. All other tanks in the liquid cycle between these two tanks would have had waste temperatures between that found in BY-112 and BY-109.

Liquid transfers between the BY tanks were completed on an almost daily basis when ITS-2 was operating. No data were found that describe the logic used to control the fluid transfers between the BY tanks. A sampling of actual ITS-2 pumping/inventory sheets for 1971 shows single transfers on an average of $50 \mathrm{kgal}$ (about $7 \%$ of the tanks filled capacity) per transfer. The data also showed high and low transfer volumes of about $25 \mathrm{kgal}$ and $75 \mathrm{kgal}$ (4\% and $13 \%$ of a tank's waste volume). Although other non-periodic isolated transfers between tanks occurred, the largest impact on individual tank temperatures would have come from the longer-term transfer cycles, such as those shown in Figure C-1.

To assure tank integrity, the upper temperature of the liquid in tank BY-112 was limited to less than $270{ }^{\circ} \mathrm{F}$ (Backman et al. 1965). The $30^{\circ} \mathrm{F}$ temperature difference between this limit and the maximum allowable tank waste temperature $\left(300^{\circ} \mathrm{F}\right)$ was considered to be ample for safe operation. The steady addition of heat to a tank from the nearly daily transfers of hot liquids was counter-acted by the forced air exchange of the tank's exhauster system and the three air-lift circulators placed in each tank. Because of the large volume of liquid in the BY tanks (500 to $700 \mathrm{kgal})$, these transfers had only a small impact on the day-to-day temperature level of a tank.

After a steady cycling of liquids, the tank waste reached a near-equilibrium temperature profile from top to bottom. The temperature data for individual tanks show that each tank in the liquid path had a lower temperature equilibrium than preceding tanks. 
Figure C-1 (1). 1971 and 1972 ITS-2 Liquid Transfer Cycles in BY Farm.

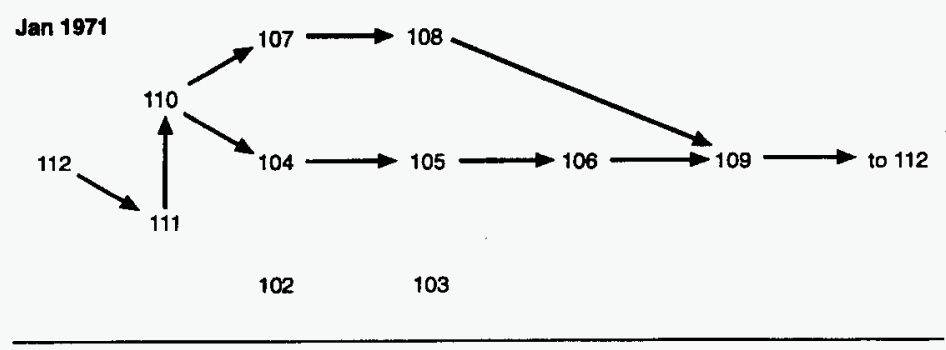

$\begin{array}{lll}\text { Fob } 1971 & 107 & 108\end{array}$

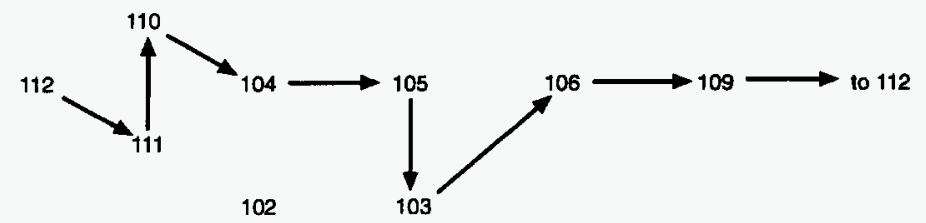

Mar 1971

$107 \quad 108$

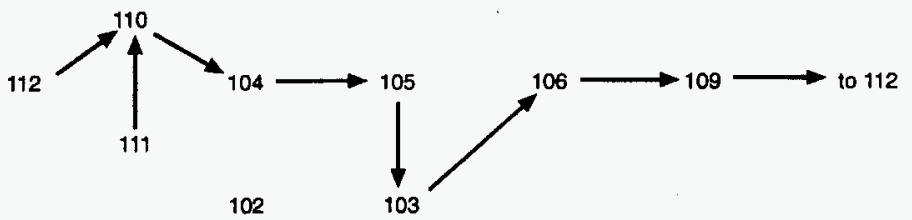

2G96040250.1 
Figure C-1 (2). 1971 and 1972 ITS-2 Liquid Transfer Cycles in BY Farm.

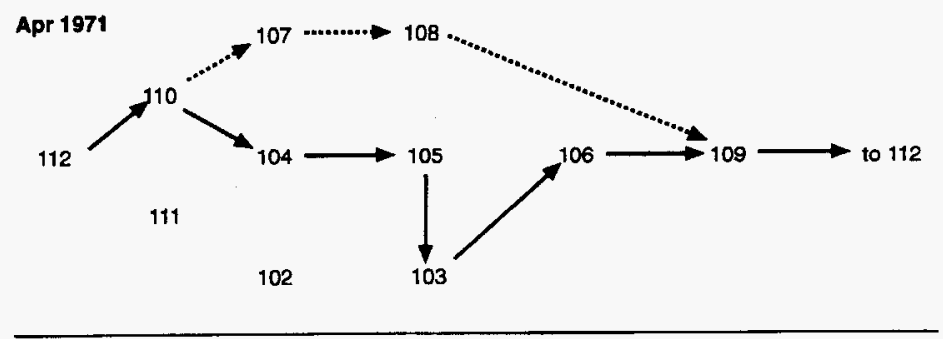

May 1971

$107 \quad 108$
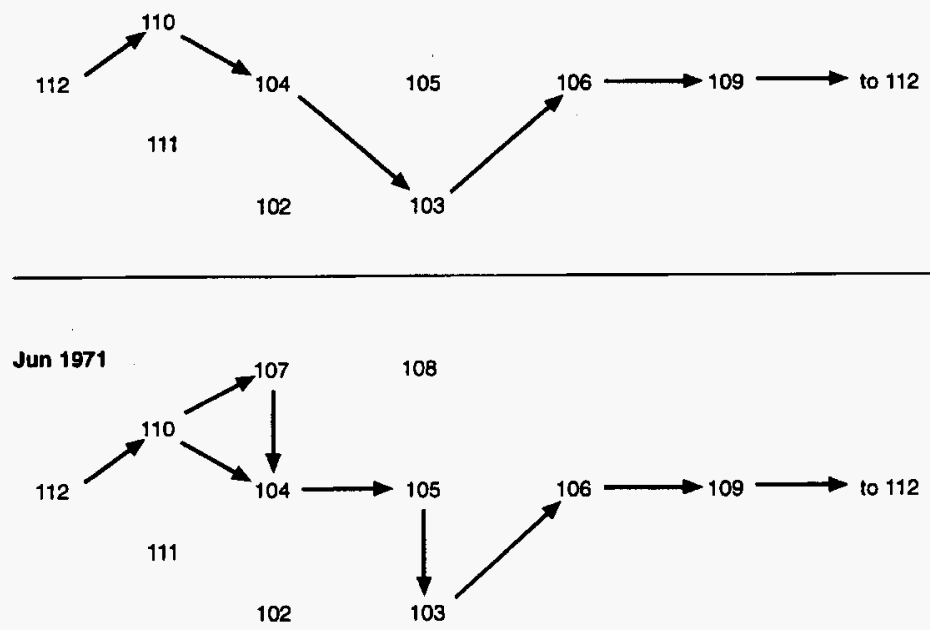

2698040250.2 
Figure C-1 (3). 1971 and 1972 ITS-2 Liquid Transfer Cycles in BY Farm.
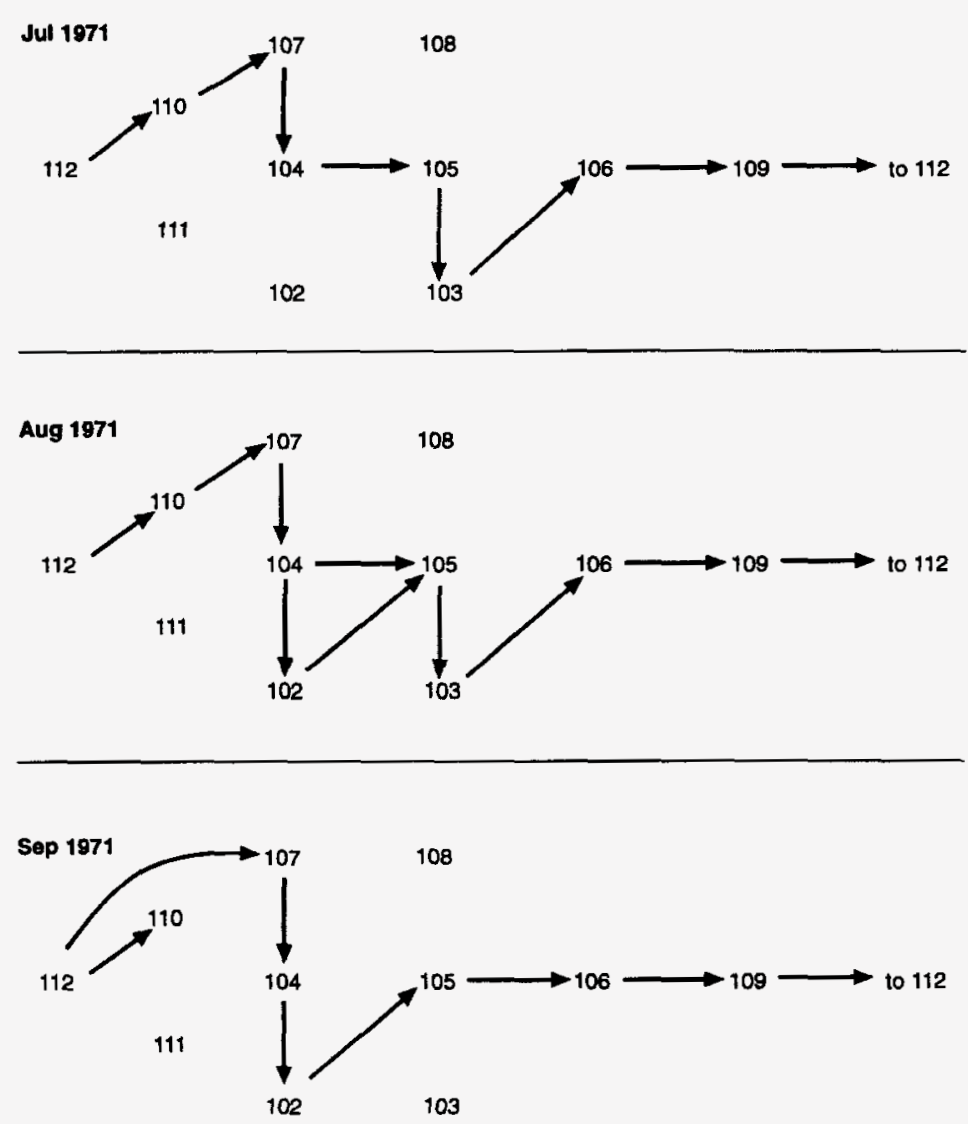

2G96040250.3 
WHC-SD-WM-SARR-038, Rev. 1

Figure C-1 (4). 1971 and 1972 ITS-2 Liquid Transfer Cycles in BY Farm.
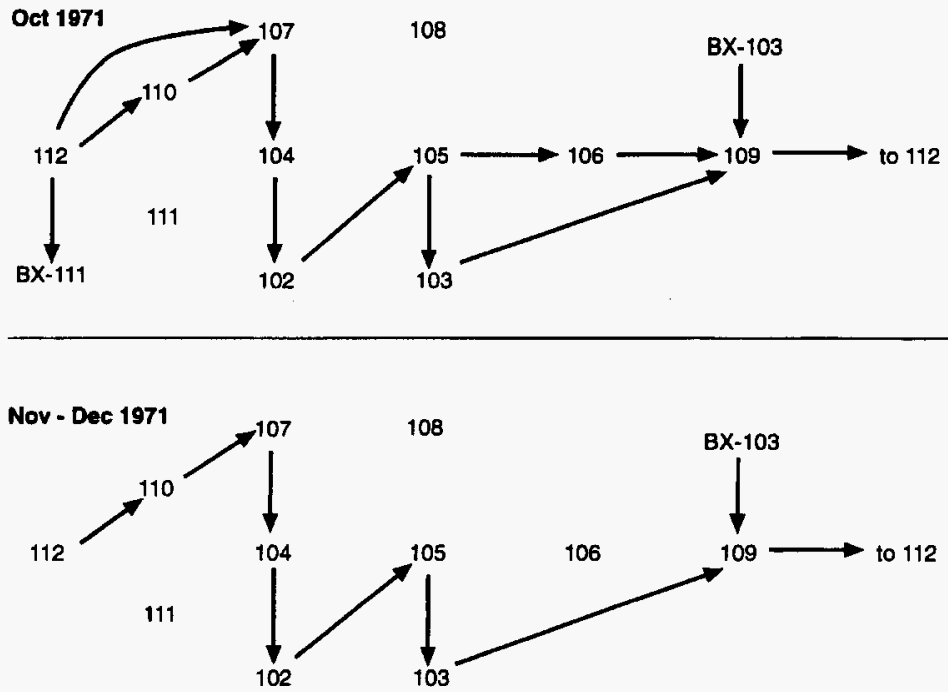
WHC-SD-WM-SARR-038, Rev. 1

Figure C-1 (5), 1971 and 1972 ITS-2 Liquid Transfer Cycles in BY Farm.

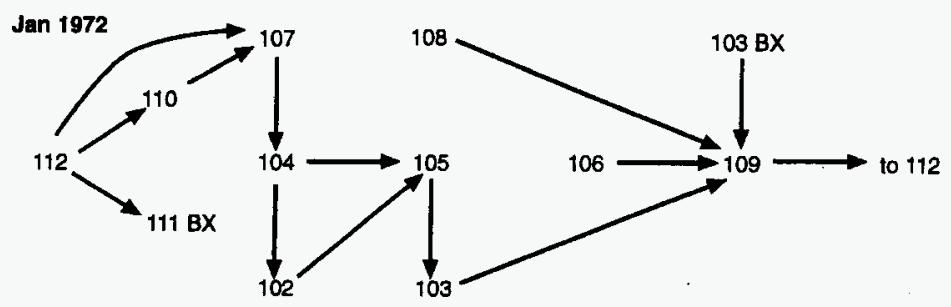

Feb 1972
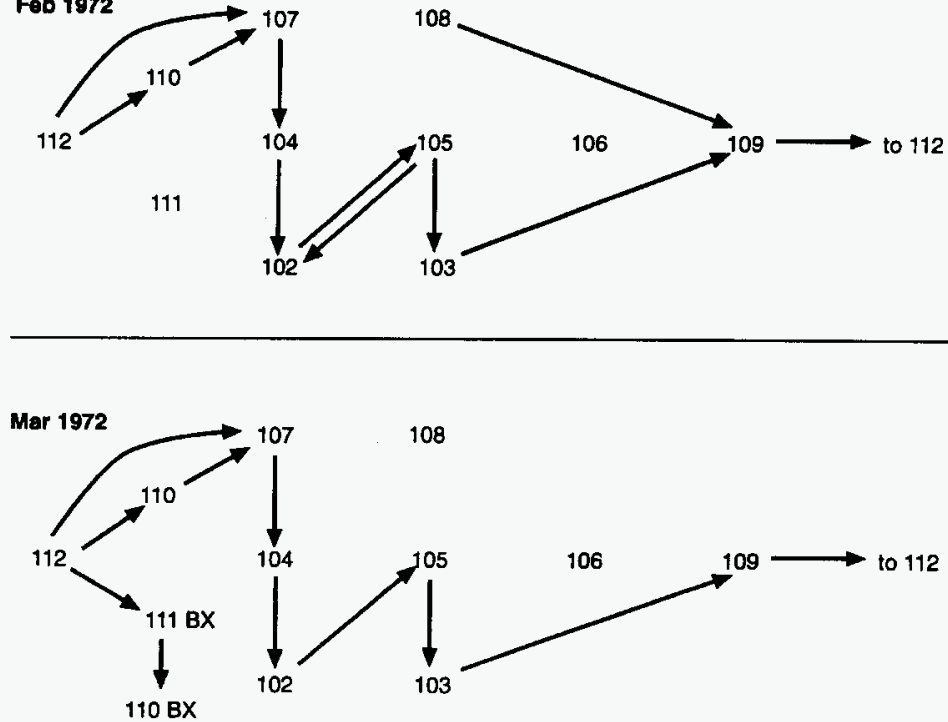

$2 \mathrm{G} 96040250.5$ 
Figure C-1 (6). 1971 and 1972 ITS-2 Liquid Transfer Cycles in BY Farm.
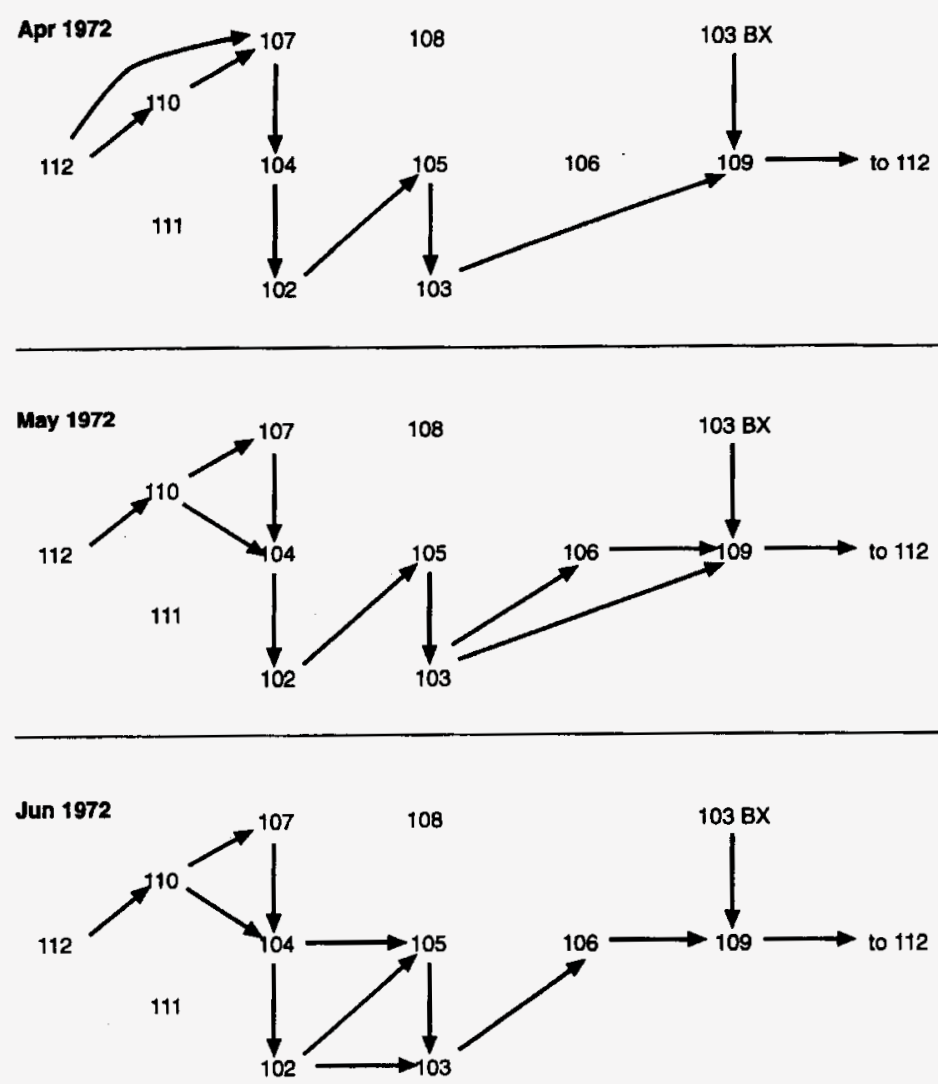

2696040250.6 


\section{C.1.4 Archived BY Farm Tank Waste Temperature Data}

The temperature data for individual BY tanks are from three documentation packages that were found in the archive data from the records holding area. These data covered only about two to three years of the seven to eight years of operating time for ITS-2.

Data for BY tank volumes and liquid transfers were found in daily ITS inventory and pumping data sheets for 1971. Data were found that covered a January 1, 1971 to December 31, 1971 time period.

Temperature data were also obtained for the time period July 1, 1972 to December 31,1972 from Operating Data ITS-2. These were daily records (or nearly daily records) of temperature sensors installed in the ITS-2 tanks for the specific purpose of providing operating data. The operating data were recorded in BY-103, BY-104, BY-105, BY-106, and BY-108 from sensors located at 2-, 10- and 16-ft distances from the tank bottom. Tank BY-109 had four sensors at 2-, 10-, 14-, and 16-ft elevations from the tank bottom. Tank BY-112 had 12 sensor positions, the first one 4 in. from the tank bottom and the others at 2-ft centers from the first sensor. Each of the tanks in the ITS-2 system, including BY-112, contained a multiple-point thermocouple probe with leads routed underground directly to the switch station located in the 254 Building Control Room.

The data in Profile Temperatures in ITS Bottoms Tanks for 1973-74 contained temperature profiles from daily readings of thermocouple trees installed ihn the BY Farm ITS tanks. Data were found that covered the January 3, 1973 to October 8, 1974 time period. The locations of the sensors for this profile data are shown in Table C-1 (Brevick et al. 1994a). Temperature data from these sensors were obtained manually, probably using portable equipment; this is thought to have contributed to some instability in the day-to-day sensor readings for these data.

The temperature of the waste and the ITS-2 heating system in tank BY-112 were critical factors in the operation and control of the ITS-2 unit. Because of this need for liquid inventory and system control, earlier data were evidently recorded for both ITS-1 and ITS-2, but to date have not been found.

Although these actual temperature data cover only a small part of the operational time of the ITS-2 system, the temperatures of the tank waste appear to be adequate to promote the aging of the ferrocyanide materials. 
Table C-1. Position of Temperature Sensors in BY Ferrocyanide Tanks

\begin{tabular}{|c|c|c|c|c|c|c|}
\hline \multirow{2}{*}{$\begin{array}{l}\text { Tanik. } \\
\text { nor. }\end{array}$} & \multicolumn{6}{|c|}{ Sensor heigh from Borken of Thank (f) } \\
\hline & $\pi$ & 19. & 87 & it4 & 185 & 176 \\
\hline BY-103 & $0.3^{*}$ & $2.3^{*}$ & $4.3^{*}$ & $6.3^{*}$ & 8.3 & 10.3 \\
\hline BY-104 & $0.4^{*}$ & $2.3^{*}$ & $4.3^{*}$ & $6.6^{*}$ & 8.5 & 10.3 \\
\hline BY-105 & $0.3^{*}$ & $2.3^{*}$ & $4.3^{*}$ & $6.3^{*}$ & NA & 10.3 \\
\hline BY-106 & $0.7^{*}$ & $2.7^{*}$ & $4.7^{*}$ & $6.7^{*}$ & 8.7 & 24.7 \\
\hline BY-107 & $0.5^{*}$ & $2.5 *$ & $\begin{array}{l}\text { NA }^{*} \\
(\sim 4.5)\end{array}$ & 6.5 & 8.5 & 10.5 \\
\hline BY-108 & $0.5^{*}$ & $2.5^{*}$ & $4.5^{*}$ & $6.5^{*}$ & 8.5 & 10.5 \\
\hline BY-109 & 2 & 10 & 14 & 16 & --- & -- \\
\hline BY-110 & $0.8^{*}$ & $2.8^{*}$ & $4.85^{*}$ & $6.8^{*}$ & 8.8 & 24.8 \\
\hline BY-111 & $\begin{array}{c}\mathrm{NA} \\
(\sim 0.3)\end{array}$ & $\begin{array}{c}\text { NA } \\
(-2.3)\end{array}$ & $\begin{array}{c}\text { NA } \\
(\sim 4.3)\end{array}$ & $\begin{array}{l}\text { NA } \\
(\sim 6.3)\end{array}$ & $\begin{array}{c}\text { NA } \\
(\sim 8.3)\end{array}$ & $\begin{array}{c}\text { NA } \\
(\sim 10.3)\end{array}$ \\
\hline BY-112 & $0.3^{*}$ & 2.3 & 4.3 & 6.3 & 8.3 & 10.3 \\
\hline
\end{tabular}

Note:

NA $=$ Information not available.

* = Temperature sensor within ferrocyanide wastes.

$(\sim 0.3)=$ Approximately $0.3 \mathrm{f}$, etc.

The temperature data occasionally show rapid changes in short periods of time, such as five to ten degrees over a one to seven day time period. Because of the large volume of material in any one of the BY tanks used in ITS-1 or ITS-2, it would have been impossible for the temperature of the waste to change this rapidly (Backman et al. 1965). Since all of the thermal data were obtained with manual methods, these rapid thermal excursions are attributed to malfunctioning equipment or errors in human judgement in the acquisition (recording and/or conversion) of the temperature data.

In the BY Tank temperature data below, the period when a tank was active with the ITS-2 system according to Anderson is shown with the temperature data and projected temperatures. This ITS-2 data was used to help project temperatures which were only available in the later years of ITS-2's operation. 


\section{C.1.5 Tank BY-112 Temperature Profiles}

The ITS-2 unit in tank BY-112 was operated for over seven years, as shown in Figure C-2, during which the waste and supernatant temperatures in BY-112 would have been consistently at high levels. Figure C-2 shows the temperature history for the lower four sensor positions from January 1973 to October 1974 . The ferrocyanide was contained at a level equal to that of the first temperature sensor $(0.3 \mathrm{ft})$.

The waste temperatures in tank BY-112 were well over $230{ }^{\circ} \mathrm{F}$ for at least 5 years. This high temperature would have had a significant impact on the rate of ferrocyanide aging.

Any supernatant moved through tank BY-112 during the ITS-2 operating time period would have also experienced temperatures of $230^{\circ} \mathrm{F}$ and higher. Any ferrocyanides in the liquid in tank BY-112 or in the liquid pumped from tank BY-112 would have also been subjected to accelerated aging.

\section{C.1.6 Tank BY-111 Temperature Profiles}

Tank BY-111 was part of the ITS-2 system for a significant time period. Tank BY-111 received liquids directly from tank BY-112 from 1968 through the first quarter of 1971 when the flow was changed to BY-110. The January 1972 cycle record shows tank BY-111 as the recipient of liquids from BY-112, while the February 1972 cycle shows flow into tank BY-110. Tank BY-111 was apparently not part of the ITS-2 flow path past 1972 . This early use of BY-111 was confirmed by ITS-2 system documentation (Caudill 1965) and transfer records from ITS inventory and pumping data sheets for 1971. Quoting from Caudill (1965): "The 241-BY-111 Tank is tentatively selected for receiving the first concentrated solution for solidification. Prior to final design, confirmation will be obtained from Operations for the use of this tank."

The waste temperature in tank BY-111 was high as a result of ITS-2 activities prior to 1972 . Although tank BY-111 did contain temperature sensors, no temperature profile data prior to 1974 have been found in the archived records. The liquid level data during the ITS-2 operating period show similar sludge and liquid levels between tanks BY-111 and BY-110 (Brevick et al. 1994a).

Because of similar positions in the ITS-2 cycle, a longer period of time as the recipient of liquids from tank BY-112, and similar liquid/sludge volumes as tank BY-110 when in ITS-2 service, tank BY-111 had waste temperatures that were at least as high as those found in BY-110. Because of BY-111's position between BY-112 and BY-110, Figure C-3 shows that $\mathrm{BY}-111$ would have had waste temperatures at least as high as BY-110 (over $190^{\circ} \mathrm{F}$ ) for about 3 years. The ferrocyanides in BY-111 experienced accelerated aging similar to that experienced by the ferrocyanide materials in tank BY-110. 
Figure C-2. Tank BY-112 Temperature Profile.

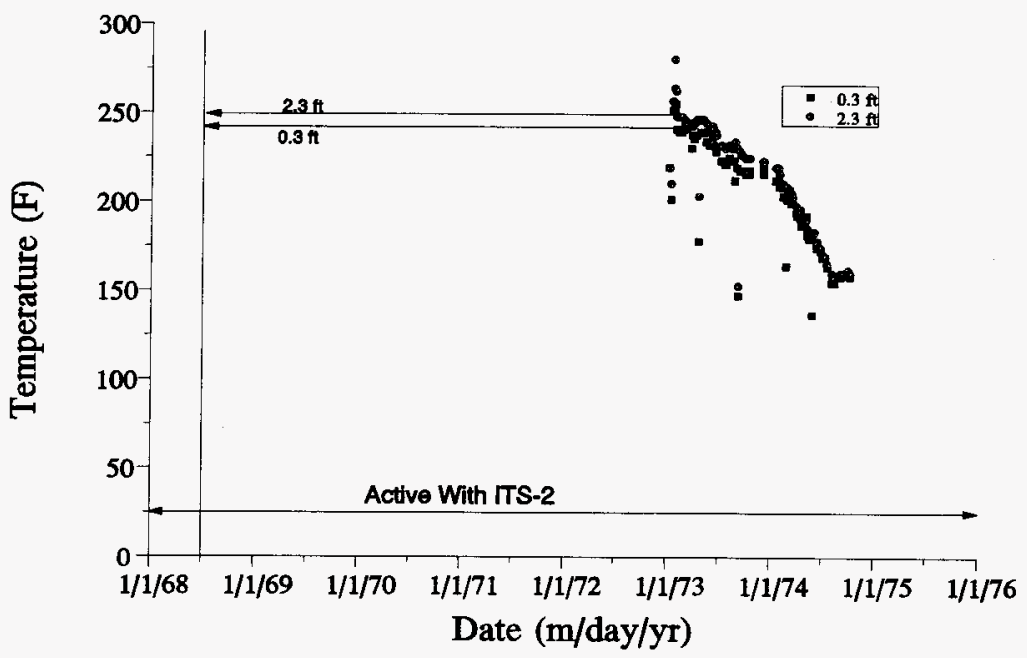


Figure C-3. Tank BY-111 Temperature Profile.

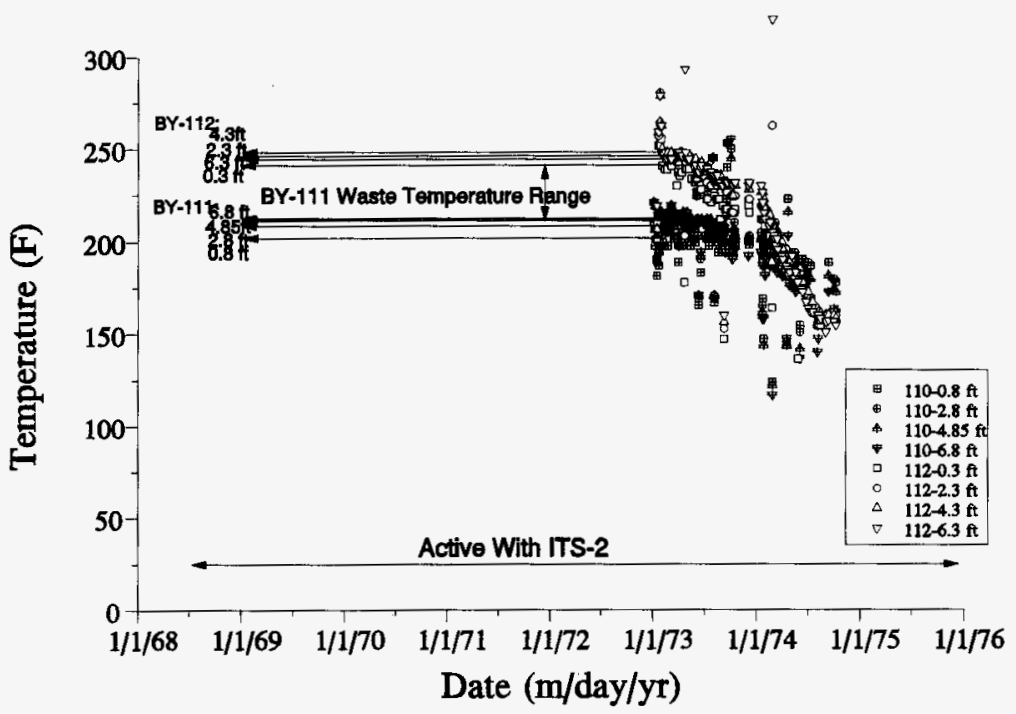




\section{C.1.7 Tank BY-110 Temperature Profiles}

As shown in Figure C-4, Tank BY-110 was in service as an ITS-2 tank at least from 1971 to 1974. Tank BY-110 received wastes from tank BY-111, probably to pre-heat the tank prior to steadily receiving wastes directly from tank BY-112. From at least 1972 until 1974 , tank BY -110 received hot wastes directly from tank BY-112, until the ITS-2 system was shut down in 1974.

During the 1973 to 1974 ITS-2 campaigns, tank BY-110 waste temperature profiles were measured with a 14-position sensor (Brevick et al. 1994a) located on 2-ft centers as shown in Table C-1. The temperature history for the lower four sensor positions is shown in Figure C-4. Over a one-year time period (January 1973 to February 1974), the temperatures of the ferrocyanide waste was well over $190^{\circ} \mathrm{F}$ for over three years. The temperature profile appears to be flat in the initial part of this time period, indicating temperatures in the $200^{\circ} \mathrm{F}$ range. These high temperatures would have had a significant impact on the rate of ferrocyanide aging.

\section{C.1.8 Tank BY-108 Temperature Profiles}

Tank BY-108 was one of the initial tanks in liquid routing for the ITS-2 (McKnight 1969). In 1972, as indicated in Figure C-5, tank BY-108 was declared to be a leaker and was not used in the later ITS-2 liquid cycling (Brevick et al. 1994a). This was confirmed as no transfer records to or from tank BY-108 were found after about July 1971.

In the early operation of ITS-2 (from 1968 to 1971), tank BY-108 received liquids directly from tank BY-107, and tank BY-105 received liquids from tank B-104. During 1973 to 1974 , temperature profiles were measured in tank BY-108 with 14 temperature sensors (see Table C-1). However, very little archived profile data were found, probably because of tank BY-108's status as an early suspected leaker.

Daily waste temperatures were also measured in tank BY-108 during ITS-2 operation with sensors at the 2-, 10-, and 16-ft levels (from ITS-2 operating data for 1972). Because these data were obtained after BY-108 was declared a leaker, they also represent data during cooldown where the bottom of the tank showed a higher temperature than the upper waste. Figure C-5 shows the temperature data for the bottom four thermocouple positions which would have covered the depth of ferocyanide material in BY-108 after it was declared a leaker.

Tank BY-108 was the feed tank for tank BY-109 for a number of years prior to 1971 . Therefore, its waste temperature would be higher than any waste temperature found in tank BY-109. Because BY-108 was located between BY-107 and BY-109 in the ITS-2 liquid cycle loop, it would have had waste tempetures between those in BY-107 and BY-109. Figure C-6 shows an estimated temperature range for BY-108, based on BY-107 and BY-109 temperature histories. 
Figure C-4. Tank BY-110 Temperature Profile.

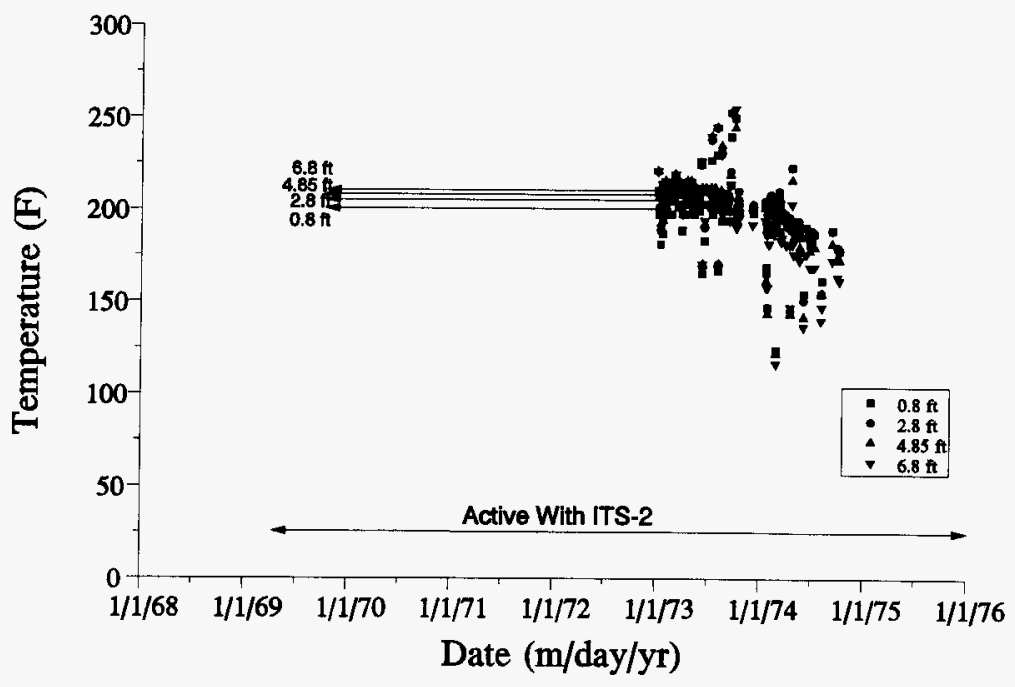


Figure C-5. Tank BY-108 Temperature Profile.

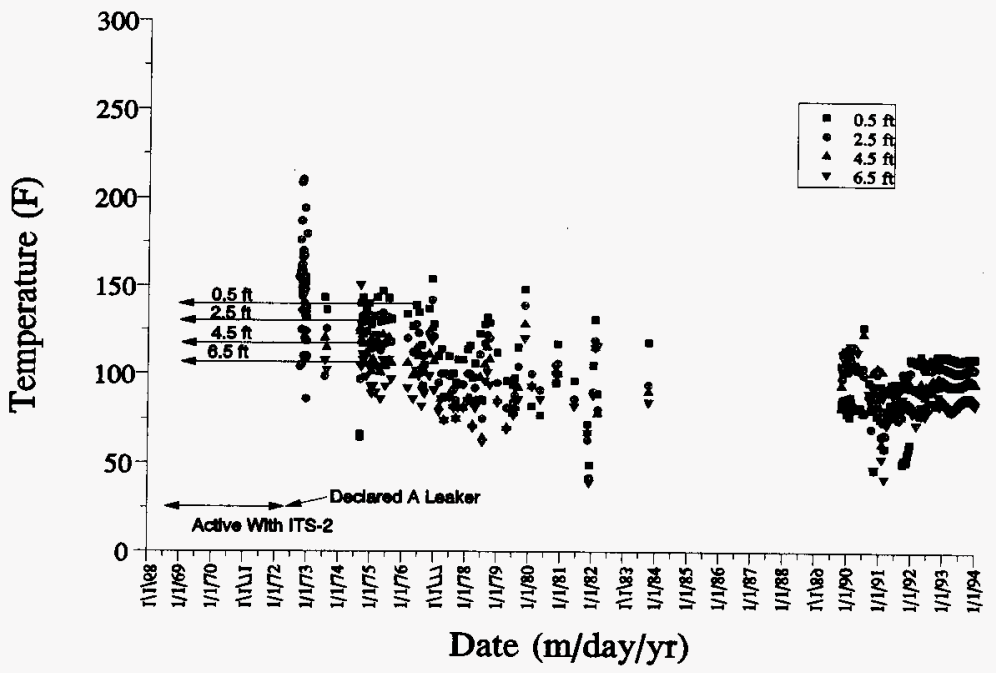


In addition, Tank BY-109 was part of the ITS-2 cycle for over three years, functioning in a similar position as BY-105. A review of the historical records shows that tanks BY-108 and BY-105 contained similar sludge and liquid levels during the ITS-2 campaigns (Brevick et al. 1994a). Tank BY-108 would then have a similar temperature profile as tank BY-105, prior to 1972 . Tank BY-105 waste temperatures from January 1973 to February 1974 exceeded $150{ }^{\circ} \mathrm{F}$.

Tank BY-108 woud have had waste temperatures between $130^{\circ} \mathrm{F}(\mathrm{BY}-109)$ and $220^{\circ} \mathrm{F}$ (BY-107) for at least three years. The available temperature data for tank BY-108, and the tank's role in ITS-2, would have elevated the waste temperatures in tank BY-108 to a level where a significant increase in the rate of ferrocyanide aging would have taken place.

\section{C.1.9 Tank BY-107 Temperature Profiles}

Tank BY-107 was part of ITS-2 for almost the entire ITS-2 operating time period, as indicated in Figure C-7 (McKnight 1969). During 1971, tank BY-107 received hot liquids from tanks BY-111 and BY-110. This history indicates that tank BY-107 would have received high-temperature liquids over an extended time period.

From 1973 to 1974 , tank BY-107 waste temperatures were measured at 14 elevations (see Table C-1). Temperature data for the lower 3 sensors are shown in Figure C-7.

Ferrocyanide waste in tank BY-107 had temperatures over $160^{\circ} \mathrm{F}$. In the earlier ITS-2 history, tank BY-107 received waste directly from tank BY-110. This would have produced the high temperatures shown in Figure C-7 for an even longer time period, starting before 1972. Prior to January 1973 , waste temperatures were probably in the 190 to $200^{\circ} \mathrm{F}$ range for over 3 years. These high temperatures would have increased the rate of ferrocyanide aging.

\section{C.1.10 Tank BY-106 Temperature Profiles}

Tank BY-106 was one of the tanks added to the ITS-2 liquid cycle at about the midpoint of ITS-2 operation, as indicated in Figure C-8. Liquid transfers to tank BY-106 were made directly from tank BY-105 during January 1971, and then from tank BY-103 during February to December 1971.

Daily waste temperatures were measured in tank BY-107 during ITS-2 operation with sensors located at the 2-, 10- and 16-ft levels. After ITS-2 was shut down (post 1973), temperatures were obtained from thermocouples located at two foot intervals within the waste. Figure C-8 shows temperatures for the waste levels that contained ferrocyanides. This shows that the temperatures of the ferrocyanide-bearing waste levels were at $140{ }^{\circ} \mathrm{F}$ for over 3 years. 
Figure C-6. Tank BY-108 Temperature Profile (2- and 10-ft Elevations).

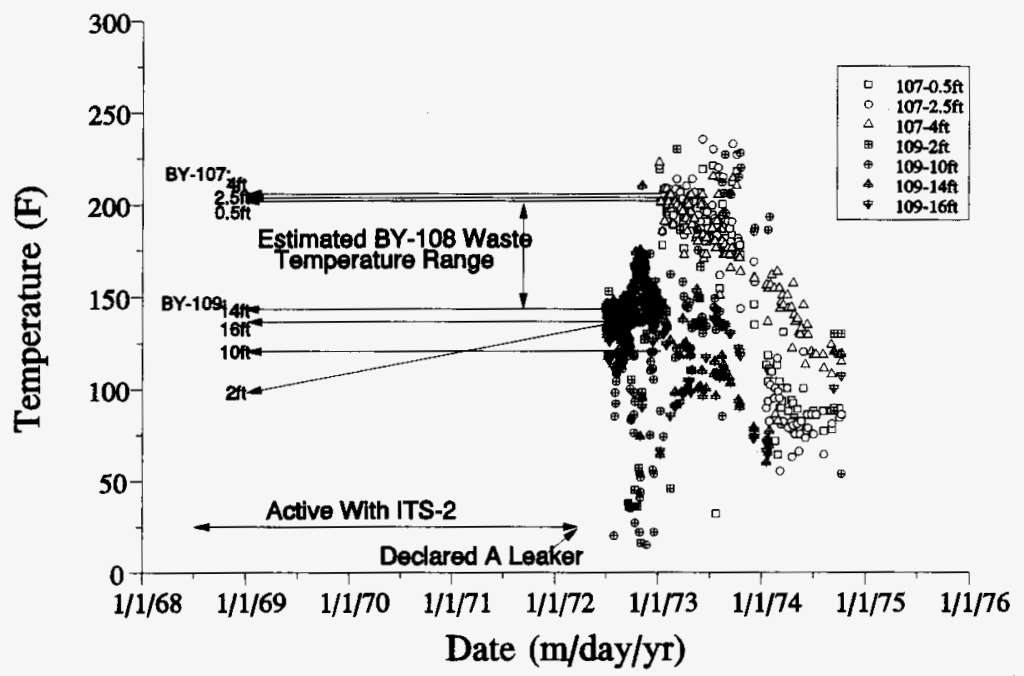


Figure C-7. Tank BY-107 Temperature Profile.

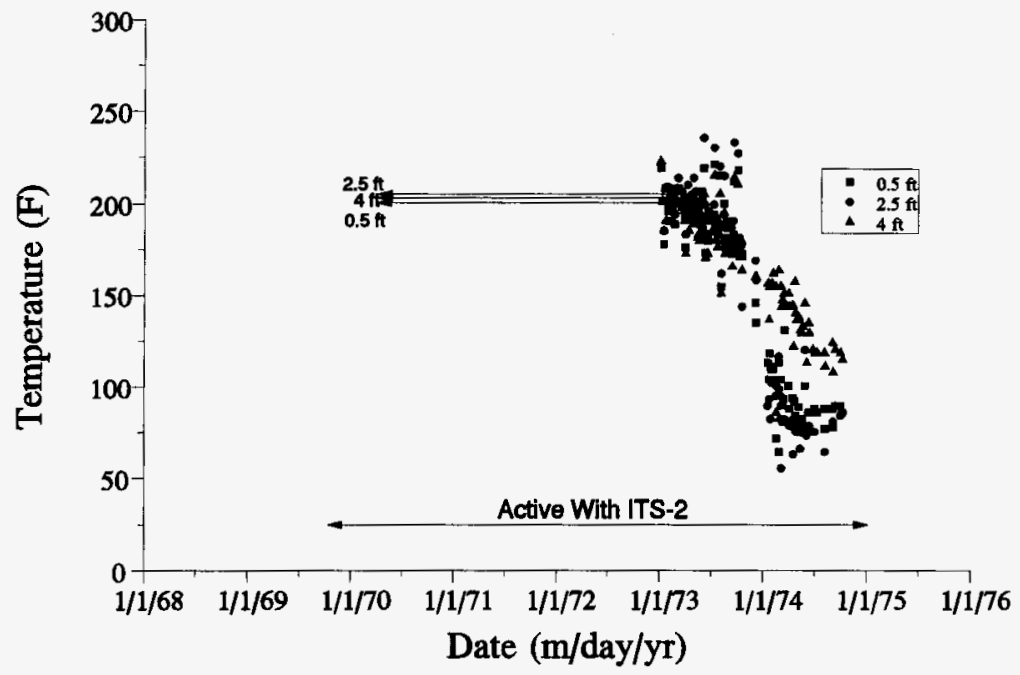


Figure C-8. Tank BY-106 Temperature Profile (2- and 10-ft Elevations).

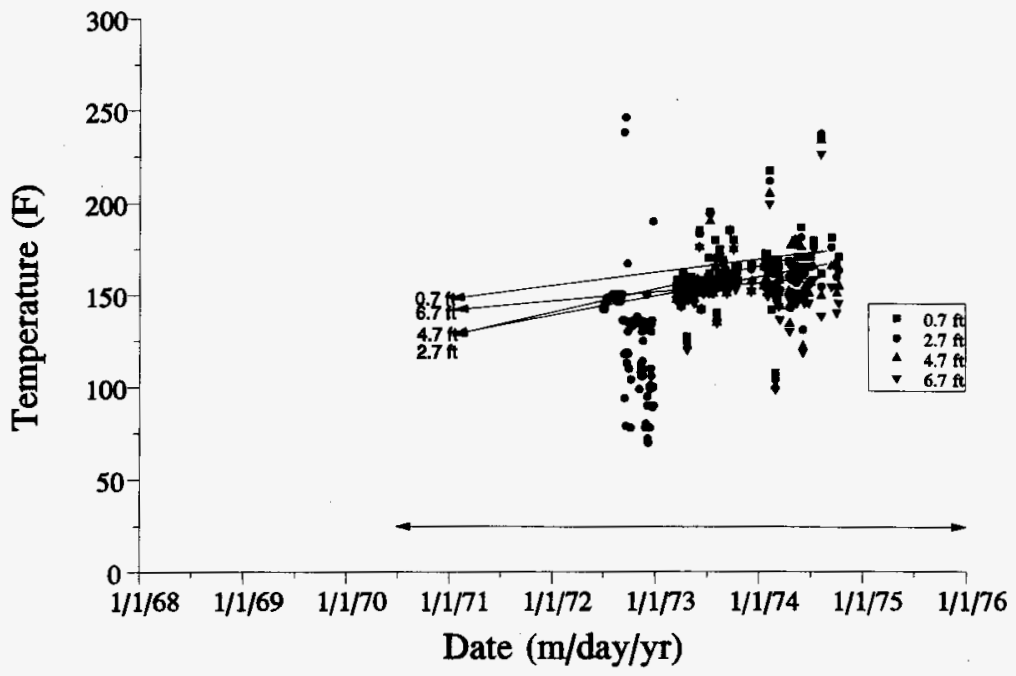




\section{C.1.11 Tank BY-105 Temperature Profiles}

Tank BY-105 was added to the ITS-2 liquid cycle at about the midpoint of ITS-2 operation. The ITS-2 liquid transfer records indicate that tank BY-105 was positioned similarly to tank BY-108 in the liquid transfer cycle. As indicated in Figure C-1, liquid transfers to tank BY-105 were made directly from tank BY-104. This would have produced waste temperatures lower than those shown for tank BY-104, but the temperatures would have been about the same as those in tank BY-108.

Daily waste temperatures were measured in tank BY-105 during ITS-2 operation with sensors located at the 2-, 10 - and 16-ft elevations with temperatures that exceeded $140^{\circ} \mathrm{F}$ from July to December 1972. Figure C-9 also shows the temperature data for the lower 4 thermocouples that was recorded later. This shows that the waste in the BY-105 ferrocyanide sludge layers were well above $140^{\circ} \mathrm{F}$ for the twelve months that where actual data was found.

Because BY-105 was between BY-104 and BY-106 in the ITS-2 cycle, the ferrocyanide temperatures would have been above $60^{\circ} \mathrm{C}\left(140^{\circ} \mathrm{F}\right)$ for three to four years. The high sustained waste temperatures indicate that there would have been a significant impact on the rate of ferrocyanide aging.

\section{C.1.12 Tank BY-104 Temperature Profiles}

Tank BY-104 was added to the ITS-2 liquid cycle at about the midpoint of ITS-2 operation. During the 1971 ITS-2 operations, Figure C-1 shows that tank BY-104 received liquids directly from tanks BY-110 and BY-107. The connection to tank BY-107 is confirmed in early ITS-2 design documentation (McKnight 1969). The liquid transferred from tank BY-110 would have been at higher temperatures than the liquids tank BY-104 received from tank BY-107. The early position of tank BY-104 in this transfer cycle (direct transfers from BY-110) would have produced similar temperatures in tank BY-104 as found in tank BY-107.

Daily waste temperatures were measured in BY-104 during ITS-2 operation with sensors located at the 2-, 10-, and 16-ft levels. In addition, temperature data was recorded from thermocouples located at 2 foot intervals in the waste. Figure C-9 shows the available temperature data for the thermocouples that were in wastes containing ferrocyanides. The waste temperatures were well above $190^{\circ} \mathrm{F}$ and often exceeded $200^{\circ} \mathrm{F}$. These high waste temperatures would have had a significant increase in the rate of ferrocyanide aging. BY-104 waste temperatures exceeded $190^{\circ} \mathrm{F}\left(88^{\circ} \mathrm{C}\right)$ for at least a 3 year time period. 
Figure C-9. Tank BY-105 Temperature Profile.

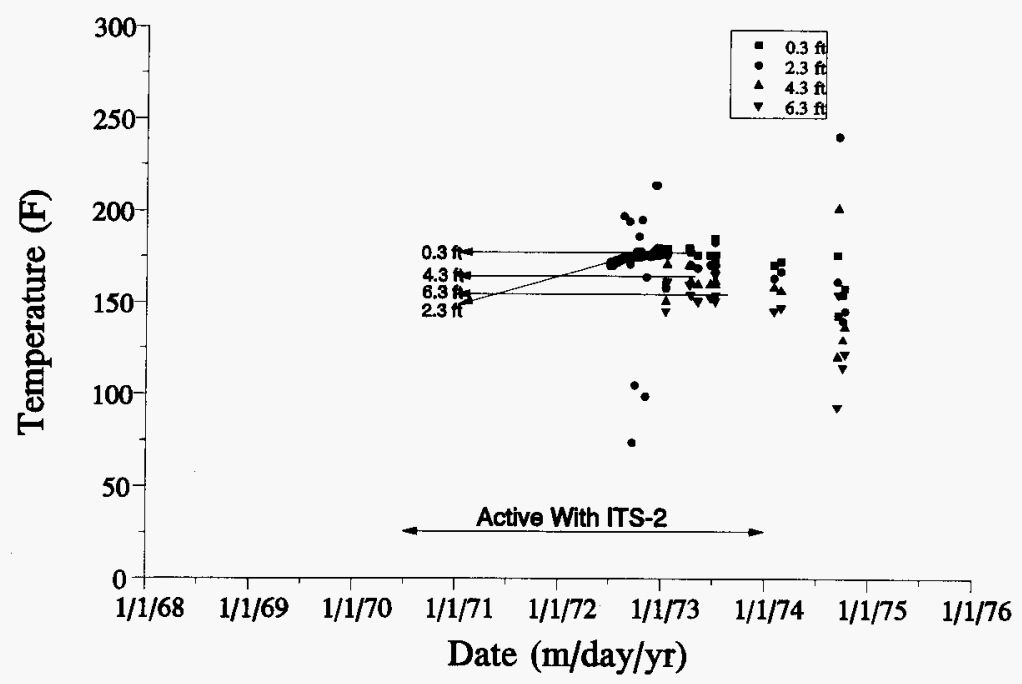


Figure C-10. Tank BY-104 Temperature Profile.

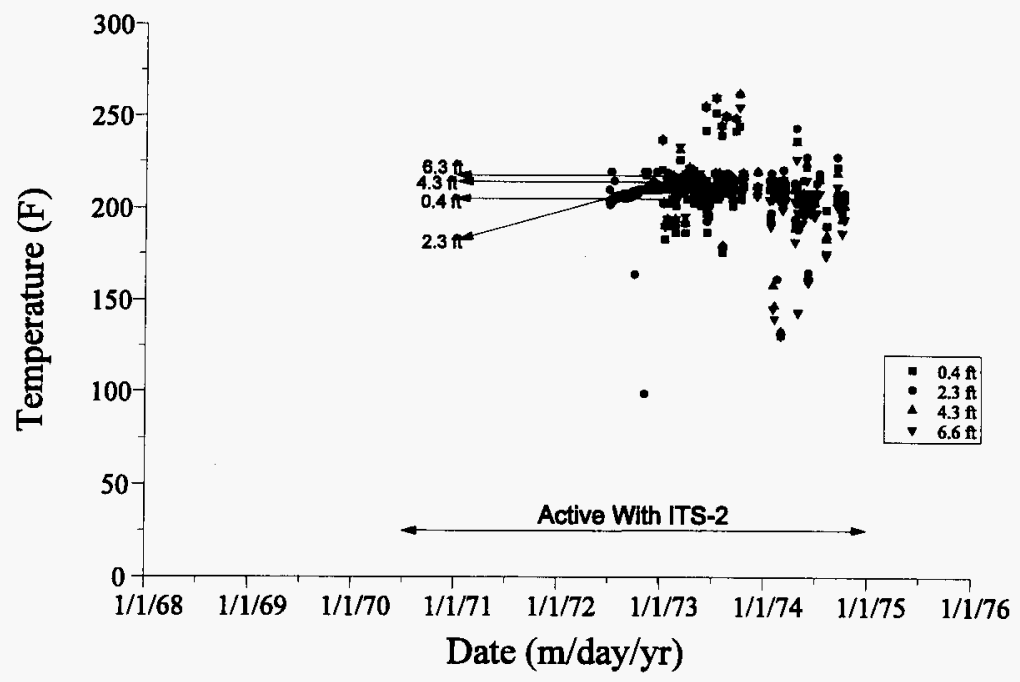




\section{C.1.13 Tank BY-103 Temperature Profiles}

Tank BY-103 was one of the tanks added to the ITS-2 liquid cycle at about the midpoint of ITS-2 operation. Figure C-1 shows that tank BY-103 was receiving liquids from tank BY-105 during ITS-2 operation. Waste in tank BY-103 would then have been at a lower temperature than that of tank BY-105, but higher than temperatures found in tank BY-106. The transfer cycle for May 1971 shows that tank BY-103 also received direct liquid transfers from tank BY-104 that would have had significantly higher temperatures than the liquids from tank BY-105.

Figure $\mathrm{C}-11$ shows the available temperature data for BY-103. This data is the daily waste temperatures that were measured in tank BY-103 during ITS-2 operation with sensors located at the 2-, 10-, and 16-ft elevations and temperature data from thermocouples at two foot intervals that was recorded at a later time period. Waste temperatures in BY-103 exceeded $130^{\circ} \mathrm{F}$ at the $2-\mathrm{ft}$ elevation and approached $150^{\circ} \mathrm{F}$ at the $6-\mathrm{ft}$ elevation. The temperature data in Figure C-11 and the tanks involvement with ITS-2, show that the tank BY-103 waste in the 4.3 to 6.3 - $\mathrm{ft}$ levels experienced a sustained temperature of over $130^{\circ} \mathrm{F}$ for over a three year time period.

\section{C.1.14 Tank BY-109 Temperature Profiles}

Although tank BY-109 is not a ferrocyanide tank, it was the last tank in the ITS-2 liquid cycle and was the feed tank for fresh material to the ITS-2 system. The temperatures in tank BY-109 would be the lowest in the ITS-2 tank cycle, and all of the other BY Tanks that were part of ITS-2 would have had higher waste temperatures.

From 1973 to 1974 , tank BY-109 waste temperature were recorded as part of ITS-2 operational control. Figure C-12 shows the available temperature data for the 2-, 10-, 14, and 16- foot elevations. Archived tank status data show that during the ITS-2 operating period the liquid level in BY-109 was above the 16-foot level.

The temperature trend for the 2-ft thermocouple shows an increasing temperature, relative to the trends for the 10-, 14-, and 16-foot levels. Tank heating would have come from the upper tank levels from liquids transferred to the tank. BY-109 was part of the ITS-2 system for its entire 7-8 year period. There may have been a lag in the lower temperature readings, but not at the time shown, which is over 4 years from the start of the ITS-2. However, this does not negate the use of BY-109's temperature data as a bound for all of the tanks that were in front of it in the ITS-2 liquid cycle.

The $130^{\circ} \mathrm{F}$ temperature in tank BY-109 is consistent with archived design goals for the ITS-2 cycle (Barnes 1972). Because BY-109 was the last tank in the ITS-2 cycle, waste temperatures in all BY tanks receiving liquids before tank BY-109 would have waste temperatures greater than $130^{\circ} \mathrm{F}$. 
Figure C-11. Tank BY-103 Temperature Profile (2.3, 4.3 and 6.3-ft Sensor Positions).

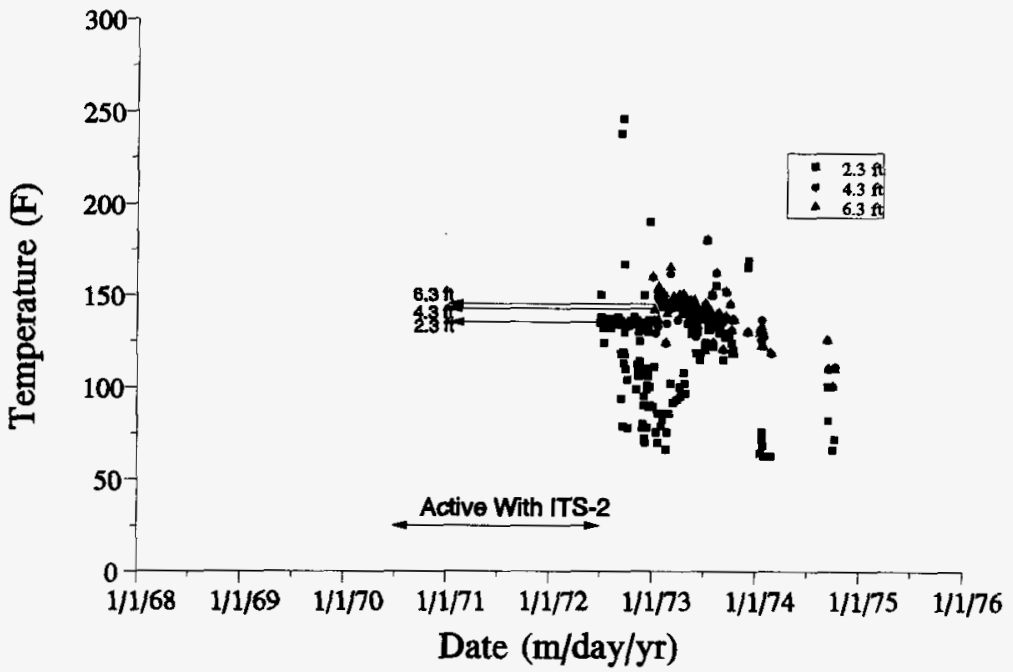


WHC-SD-WM-SARR-038, Rev. 1

Figure C-12. Tank BY-109 Temperature Profile (2-, 10-, 14- and 16-ft Elevations).

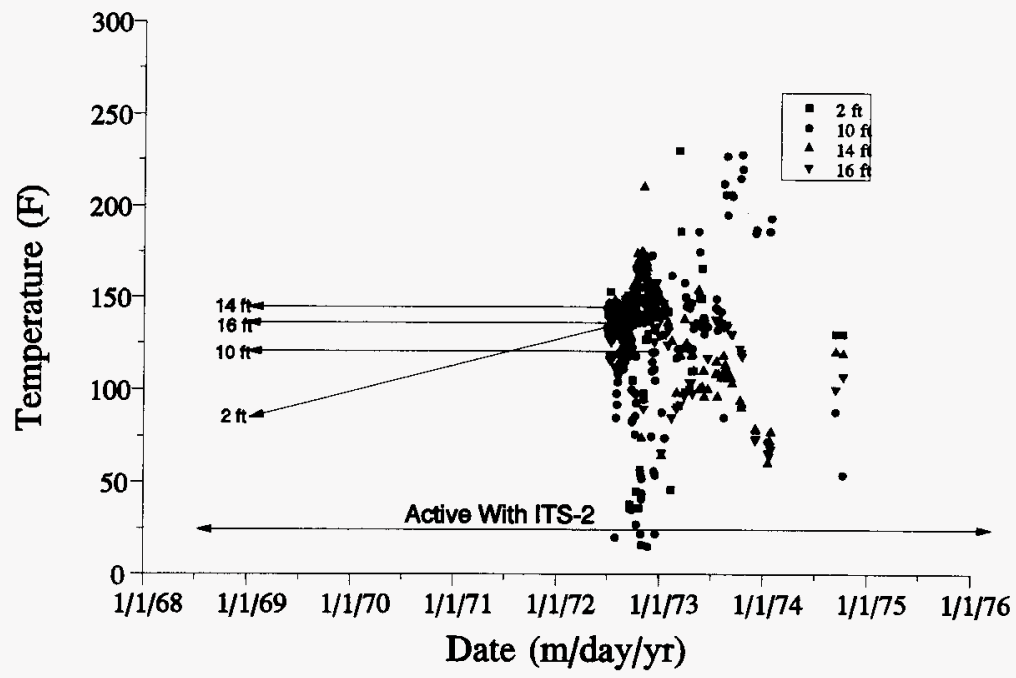




\section{C.2 C FARM TANK HISTORIES}

The single-shell tanks in the C Tank Farm were constructed at the Hanford Site between 1943 and 1944 (Brevick et al. 1994b). The C Farm tanks were designed for non-boiling waste with a maximum fluid temperature in the $220^{\circ} \mathrm{F}$ range. Tanks $\mathrm{C}-112, \mathrm{C}-111, \mathrm{C}-109$, and $\mathrm{C}-108$ are approximately $75 \mathrm{ft}$ in diameter, built for an operating capacity of $530 \mathrm{kgal}$ (fill depth of approximately $16 \mathrm{ft}$ ), and were covered with approximately $2.2 \mathrm{~m}(7.5 \mathrm{ft}$ ) of overburden.

Tanks C-112, C-111, C-109, and C-108 received a number of different waste types, including first-cycle waste, B Plant decontamination waste, U plant waste, evaporator bottoms, coating wastes, and hot semiworks wastes. During the 1954 to 1957 time frame, tanks C-112, C-111, C-109, and C-108 were also used as primary settling tanks for the In Farm scavenged uranium waste that originated in various East Area tanks. These tanks received the highest concentration of ferrocyanide materials.

\section{C.2.1 C Farm Waste Temperature History}

Figures $\mathrm{C}-13$ through $\mathrm{C}-15$ show archived temperature data that was found for tanks $\mathrm{C}-112$, C-111, and C-109 (Mercier et al. 1984). The temperature indicated that this was the "bulb" temperature or "temperature of the annulus air." All available information and conversations with people who were at the Hanford Site during this 1961 to 1965 time period indicate that this bulb temperature was the temperature of the air in the headspace of the tanks. During the $1960 \mathrm{~s}$, these tanks were actively ventilated. Headspace psychrometric data (dew point) were recorded for a number of tanks in order to separate liquid loss caused by evaporation from liquid loss caused by a leak. An examination of other tanks where both waste and head space temperature were recorded, show that the wastes and the headspace temperatures tracked each other very closely, with less than a $10^{\circ} \mathrm{F}$ between headspace and waste readings. This is specifically shown with "bulb" and waste temperature data that were both recorded for Tank A-103 for the 1967-1969 time period (Mercier et al. 1984).

From 1961 to 1965 , tank waste status records show that tanks C-108, C-109, C-111, and C-112 received periodic transfers of hot semiworks waste (Brevick et al. 1994b, Anderson 1990). This waste was from the strontium or hot semiworks processing facility (located at C Plant) that was built as a hot pilot plant for the reduction-oxidation (REDOX) process, but was later converted to a pilot plant for the plutonium-uranium extraction (PUREX) process.

The feedstock for this plant was fresh process wastes from the PUREX plant, referred to as PUREX crude. This waste would have contained a full complement of short and long half-life isotopes, which were major heat generators when this waste was transferred to storage tanks. The archived documentation on the hot semiworks also indicates that the hot semiworks wastes were concentrated by about a factor of three in A Cell (using thermal evaporation) before the waste was discharged to the C Farm tanks. A summary of the hot semiworks transfers to these C Farm tanks is shown in Table C-2 (Anderson 1990). 
Figure C-13. Archived Temperature Data for Tank C-112.

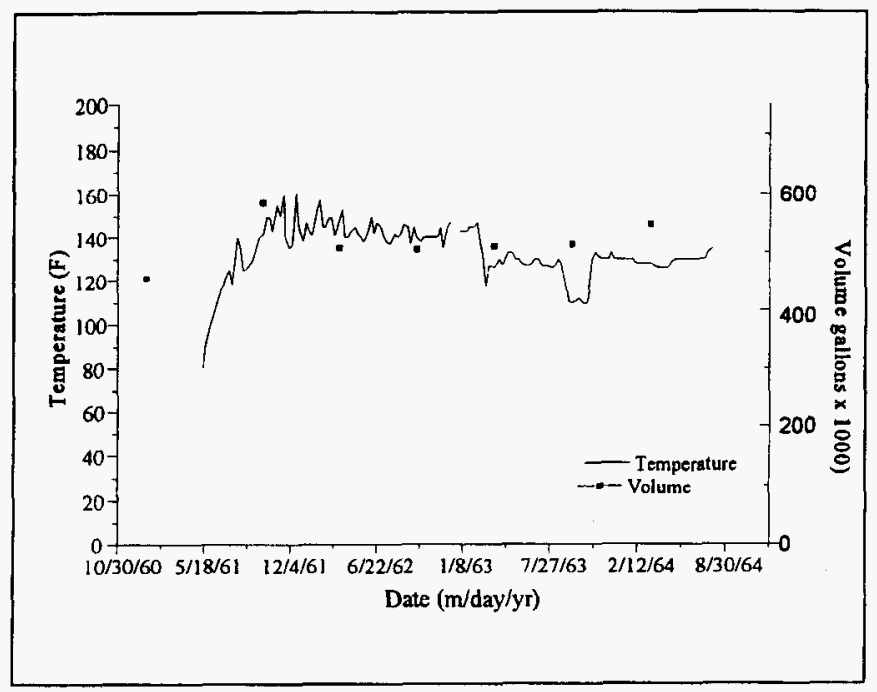


WHC-SD-WM-SARR-038, Rev. 1

Figure C-14. Archived Temperature Data for Tank C-111.

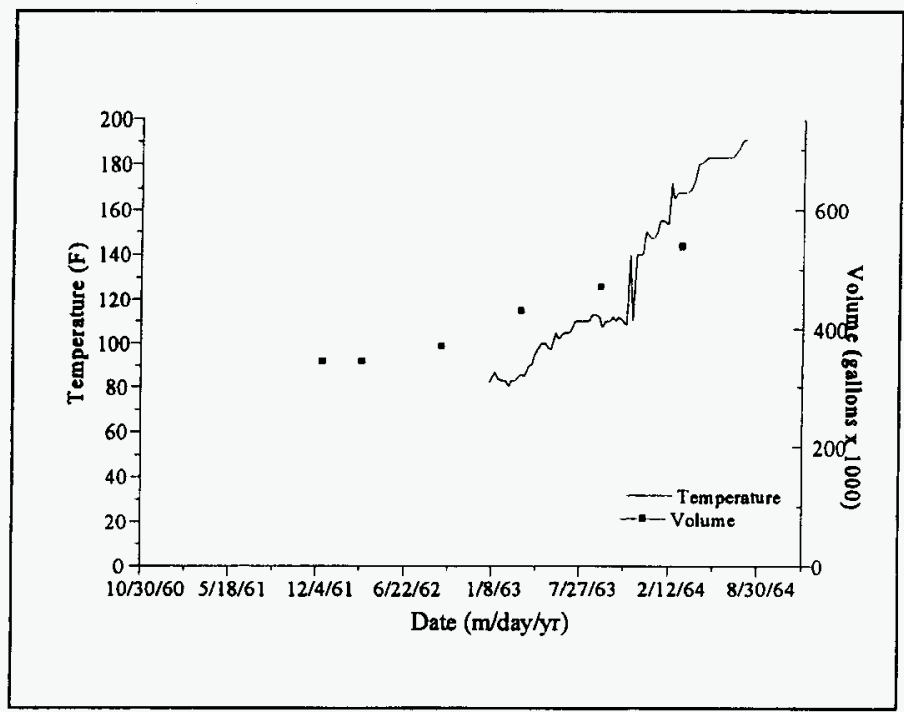


WHC-SD-WM-SARR-038, Rev. 1

Figure C-15. Archived Temperature Data for Tank C-109.

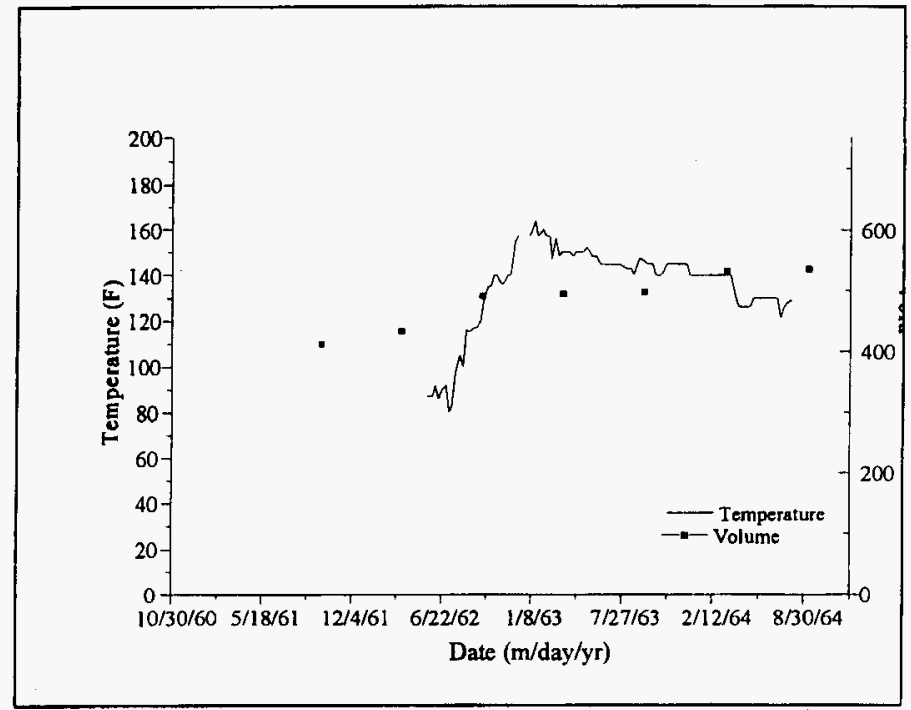


Table C-2. Hot Semiworks Waste Transfers From 1961 to 1965

\begin{tabular}{|c|c|c|c|}
\hline train & 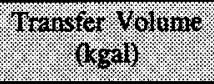 & 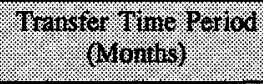 & 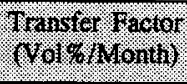 \\
\hline C-108 & 142 & 3 & 11.1 \\
\hline C-109 & 132 & 39 & 0.8 \\
\hline C-111 & 228 & 21 & 3.1 \\
\hline C-112 & 58 & 9 & 1.3 \\
\hline
\end{tabular}

This combination of short-life isotopes and thermally hot waste would have injected a significance source of heat into these tanks that would have produced the temperatures shown in Figures C-13 through C-15. Because the source of heat for the headspace air was from the tank waste, the high air temperatures (over $140^{\circ} \mathrm{F}$ ) for tanks $\mathrm{C}-109, \mathrm{C}-111$, and $\mathrm{C}-112$ would have required waste at an even higher temperature for this 1961 to 1964 time period.

No archived bulb temperature data were found for tank C-108. However, as shown in Table C-2, tank C-108 was also the recipient of waste from the hot semiworks facility during the 1961 to 1964 time period. To compare tank C-108 with the other C Farm tanks, Table $\mathrm{C}-2$ shows a fill factor that is the volume percent/month change that a tank would have experienced from the transfers of hot semiworks wastes it received. Tanks C-109, C-111, and $\mathrm{C}-112$ all show about a $1 \%$ volume per month change during the hot semiworks activities. Tank $\mathrm{C}-108$ shows an even higher (11\%) per month change factor that would have had a very strong impact on the temperature of tank C-108. From 1975 to present, temperatures for tanks C-108, C- $109, \mathrm{C}-111$, and $\mathrm{C}-112$ have been below $100^{\circ} \mathrm{F}$ (Brevick et al. 1994b).

Although archived bulb temperature data were not found for tank C-108, based on similar hot semiworks transfer activities, it can be assumed that the tank $\mathrm{C}-108$ waste experienced a period of high temperature similar to that experienced by tanks C-109, C-111, and C-112.

\section{C.4 TANK TX-118}

The TX Tank Farm, constructed between 1947 and 1948, consists of $18758-\mathrm{kgal}$, 75-ft-diameter single-shell tanks covered with about $2.4 \mathrm{~m}(8 \mathrm{ft})$ of overburden (Brevick et al. 1995a). These tanks were single-shell tanks, designed for non-boiling wastes with a maximum fluid temperature of $220^{\circ} \mathrm{F}$. Tank TX-118 was the last in a three-tank cascade series that included tanks TX-116 and TX-117 (TX-116 to TX-117 to TX-118).

Tank TX-118 never received ferrocyanide waste and was erroneously placed on the ferrocyanide Watch List because of an error in track radionuclide component (Borsheim and 
Simpson 1991). Initially, tank TX-118 never received waste directly from a process plant, such as REDOX or PUREX, that would have had a high fission product content. Starting in 1951, tank TX-118 received first-cycle decontamination waste through transfers from other $\mathrm{T}$ Farm tanks (Agnew et al. 1995a). In 1952, part of the waste transferred to tank TX-118 included evaporator bottoms.

In the second quarter of 1952 through 1955 , tank TX-118 was used as the evaporator feed tank for the 200 West Area evaporator and received mostly first-cycle decontamination and tributyl phosphate (TBP) liquids from other T Farm tanks. In 1955, tank TX-118 was nearly emptied in preparation for its use as a feed tank for the ferrocyanide scavenging operation.

In 1957, tank TX-118 began to accumulate small batches of evaporator bottoms and TBP wastes directly from 221-U (U Plant) that nearly filled the tank. This accumulation continued until the fourth quarter of 1960 when small, periodic transfers of evaporator bottoms and decontamination waste were then made to tank TX-118 from 221-T. The transfers from 221-U continued until about the fourth quarter of 1965 . This would have produced elevated temperatures in tank TX-118.

In 1965, tank TX-118 became the feed tank for 242-T evaporator waste and received periodic transfers from a number of TX, TY, S, SX and U tanks through 1976. Activities ceased with tank TX-118 around 1979 and the tank was labelled as inactive in 1980 when a level adjustment was made. The tank was interim stabilized in 1983 and is currently classified as a sound, stabilized tank.

As shown in Figure C-16, temperature data for TX-118 was found starting from January 1974 (Brevick et al. 1995a). Figure C-20 shows temperatures for the bottom 6.5 feet of tank sludge. The temperature profile of the waste decreases from bottom to top, with the highest temperature at the bottom first and second thermocouple positions. These temperature features indicate that (prior to 1974) the waste in tank TX-118 was at an elevated temperature. The mechanism for producing this elevated temperature is not known, because tank TX-118 was used as an evaporator feed during the mid 1970s when this higher temperature level would have occurred.

The use of tank TX-118 to contain evaporator bottoms and decontamination waste transferred from 221-U would have elevated its waste temperatures. It is reasonable to assume that waste in tank TX-118 exceeded 130 to $140^{\circ} \mathrm{F}$ and possibly higher. Even if tank TX-118 would have received ferrocyanide waste, temperatures in the tank were sufficiently high enough for aging to have occurred. 
WHC-SD-WM-SARR-038, Rev. 1

Figure C-16. Tank TX-118 Temperature Data.

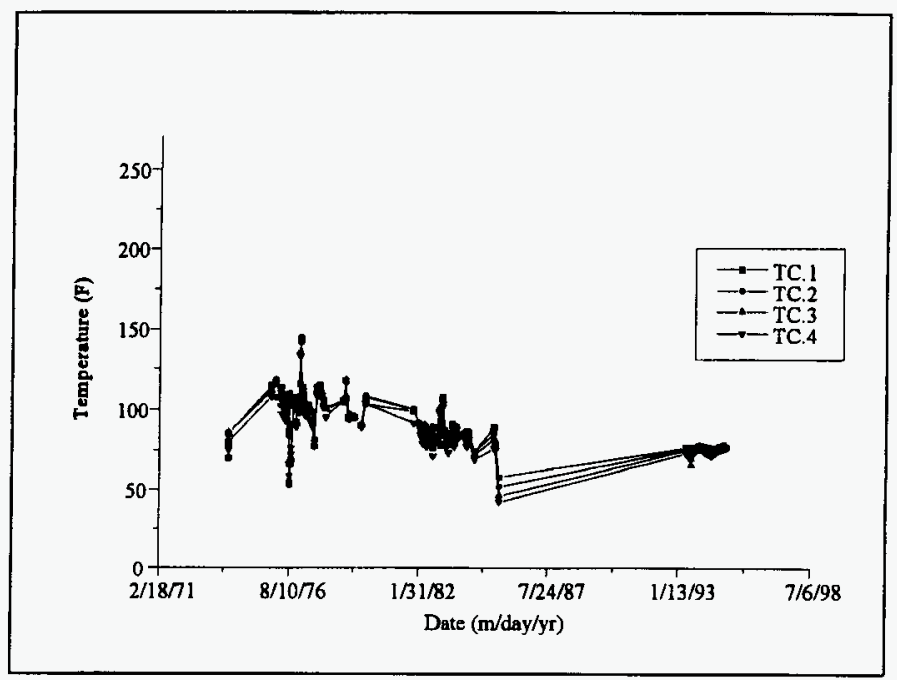




\section{C.5 TY TANKS}

The TY Tank Farm, constructed between 1951 and 1952, consists of six 758-kgal,

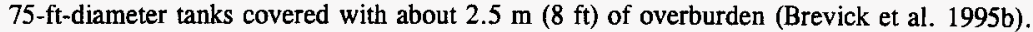
These tanks were single-shell tanks, designed for non-boiling wastes with a maximum fluid temperature of $220^{\circ} \mathrm{F}$. The tanks were arranged in two-tank cascade series, with TY-101 cascading to TY-102, TY-103 cascading to TY-104, and TY-105 cascading to TY-106.

The available archived temperature data for tanks TY-101, TY-103, and TY-104 dates back to about 1970. This data shows temperatures between 65 and $70^{\circ} \mathrm{F}$, and no temperature trends that would indicate cooling from recent higher waste temperatures. The lack of a temperature trend indicates that tanks TY-101, TY-103 and TY-104 had a fairly low temperature history just prior to the 1970s. However, transfers in the $1950 \mathrm{~s}$ and early $1960 \mathrm{~s}$ would have impacted the bulk temperatures.

\section{C.5.1 TY Ferrocyanide Waste History}

The TY tanks received a number of different waste types during their active history (Agnew et al. 1995a, Brevick et al. 1995a). According to historical records, the ferrocyanide concentration in tanks TY-101, TY-103 and TY-104 never exceeded $10.7 \mathrm{wt} \%$. Because these TY tanks never received significant amounts of high-level wastes, their temperature levels would have been relatively low. However, the temperatures were impacted by liquid transfer from tanks that had higher temperatures.

Tank TY-101 began receiving 242-T evaporator bottoms in 1953 from tank TX-117 transfers. From 1954 to 1956 , tank TY-101 received first-cycle ferrocyanide waste from T-Plant. From 1966 to 1968 , tank TY-101 was involved with a number of transfers involving tanks from other tank farms. Saltwell pumping was completed in 1977.

Tank TY-103 received TBP waste from 1953 to 1954, first-cycle decontamination waste from 1955 to 1968, and first-cycle ferrocyanide scavenged waste in 1955 and 1956 . In 1973, the tank was declared a leaker and became inactive in 1976. The tank was interim stabilized in 1983 and intrusion prevention completed in 1984.

Tank TY-104 received a number of interspersed waste types during its lifetime. The tank began receiving tri-butyl phosphate waste in 1953, which continued until 1969. It also received first-cycle decontamination waste from 1955 until 1966. In 1955, tank TY-104 received a significant transfer $(500 \mathrm{kgal})$ from tank TY-103, which is the source of ferrocyanide waste in tank TY-104. Some mixing and dilution occurred during these transfer operations, as evidenced by the low nickel concentrations found in this tank (see Section 5.0 or Appendix A for nickel and cyanide data).

From 1961 to 1971 , tank TY-104 received decontamination waste. From 1970 to 1976 , it received REDOX waste, PUREX organic wash waste, REDOX ion exchange waste and $B$ 
Plant low-level waste. Tank TY-104 was removed from service in 1974 and declared an assumed leaker in 1981. The tank was administratively interim stabilized in 1983.

\section{C.5.2 TY-101 Summary of Waste Transfer and Temperature Histories}

Archived temperature data are available for tank TY-101 from 1971 to present (Flanagan 1994). Since 1971, tank TY-101 has had a low waste temperature (65 to $70{ }^{\circ} \mathrm{F}$ ) and no cooling trend that would indicate a near-term period of higher temperatures. The historical waste content record shows that tank TY-101 did not receive wastes that would have generated a large quantity of heat from fission product decay (i.e., direct transfers from PUREX and REDOX) (Agnew et al. 1995a).

Prior to receiving its ferrocyanide wastes in the first quarter of 1954 , tank TY-101 did receive about $750 \mathrm{kgal}$ of evaporator bottoms waste. However, in the third quarter of 1954 , about $700 \mathrm{kgal}$ were transferred to a crib, nearly emptying the tank. This would not have left a significant source of hot waste in tank TY-101 when the ferrocyanide materials were added later.

In the first quarter of 1956 , tank TY-101 received about $750 \mathrm{kgal}$ of first-cycle decontamination waste from $\mathrm{T}$ Plant that was from the $\mathrm{BiPO}_{4}$-based process. This often included cladding waste, which held only about $10 \%$ of the fission products compared with $90 \%$ in the metal wastes from this process. It is, therefore, not a high-heat-generating waste. In the fourth quarter of 1956 , the tank was nearly emptied $(550 \mathrm{kgal})$ again, so that the waste had a residency time in tank TY-101 of less than one year.

As shown in Table C-3, in the third quarter of 1959 , tank TY-10I received a significant waste transfer from tank TY-106 (about $475 \mathrm{kgal}$ ), filling it to about the 700-kgal level. This waste in TY-106 was TBP and first-cycle TBP waste from uranium recovery operations, which was not a high-heat-producing waste. Tank TY-106 had been nearly static with TBP after receiving supernatant cascade from tank TY-105 and TBP wastes.

Tank TY-101 level/status remained static until 1966 when about $400 \mathrm{kgal}$ of waste was sent to tank TX-118, leaving about $260 \mathrm{kgal}$ in the tank. In the first quarter of $1967,492 \mathrm{kgal}$ were transferred to tank TY-101 from SX-103, filling the tank to its 755 -kgal capacity.

Although the previous waste temperature in tank SX-103 had been in the 180 to $200{ }^{\circ} \mathrm{F}$ range, most of the waste had been transferred to tank TX-101 (525 kgal), leaving about $130 \mathrm{kgal}$ in tank SX-103. This was then mixed with about $320 \mathrm{kgal}$ (a $3: 1$ dilution) of low-temperature waste from tank SX-105 before the tank TY-101 transfer was made, reducing the waste temperature in tank $\mathrm{SX}-103$ to well below its previously high levels. The transfer to tank TY-101 from tank SX-103 was further diluted $(2: 1)$ because of the residual waste in tank TY-101. The temperature of the waste in TY-101 as a result of these transfers would have been in the 100 to $120^{\circ} \mathrm{F}$ or less range. 
Table C-3. TY-101 Waste Transfers Indicating Pre-1971 Waste Temperature History ${ }^{a}$

\begin{tabular}{|c|c|c|c|}
\hline Tear . Piarrer: & 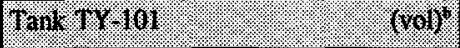 & max $6 x+106$ & 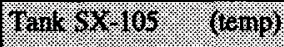 \\
\hline $1953-3$ & 556 from $\mathrm{TX}-117$ & & \\
\hline $1954-4$ & 340 from TX-116, -140 to TY-102 & & \\
\hline $1954-1959$ & 1 Cycle Ferrocyanide wastes & & \\
\hline $1959-3$ & 475 from TY-106 (TBP waste) & & \\
\hline $1963-4$ & & $\begin{array}{l}-660 \text { to TX-101 }\left(150^{\circ} \mathrm{F}\right)^{\mathrm{C}} \quad(140) \\
484 \text { from SX-111 }\left(180^{\circ} \mathrm{F}\right)^{\mathrm{c}} \quad(610)\end{array}$ & \\
\hline $1964-2$ & & -529 to $\mathrm{TX}-101$ & \\
\hline $1965-2$ & & $\begin{array}{l}514 \text { from } S X-110 \\
\left(S X-110 \text { at } 200-220^{\circ} \mathrm{F}\right)\end{array}$ & -132 to $202 \mathrm{~S} \quad\left(120^{\circ} \mathrm{F}\right)$ \\
\hline 1966-3 & -399 to $\mathrm{TX}-118$ & -525 to $\mathrm{TX}-101$ & \\
\hline $1964-4$ & & 320 from $\mathrm{SX}-105$ & -320 to $S X-103$ \\
\hline $1967-1$ & 492 from $S X-103$ & -492 to TY- 101 & \\
\hline $1967-1973$ & (Static, no transfer activities) & & \\
\hline 1974-1 & Suspect leaker & & \\
\hline $1976-4$ & Salt well pumped & & \\
\hline $1977-2$ & Stabilization complete & & \\
\hline
\end{tabular}

Note:

- Data from Agnew et al. 1996.

b Gallons x 1000

c Data from Mercier et.al (1984). 
Tank T-101's waste level was static from 1967 until about 1973 when the tank was emptied over a one year time period (removal of about $600 \mathrm{kgal}$ ) after it was a suspected leaker. This left about $170 \mathrm{kgal}$ of solids in the tank.

From this data, it is estimated that the maximum waste temperature in tank TY-101 (after receiving the ferrocyanide wastes) was probably less than $120^{\circ} \mathrm{F}$. The 1971 temperature data show a fairly constant temperature in the 65 to $70^{\circ} \mathrm{F}$ range, with no strong temperature trends. This is consistent with the argument that TY-101 never held high-temperature wastes for a time sufficient to raise the waste temperature levels.

\section{C.5.3 TY-103 Summary of Waste Transfer and Temperature Histories}

Archived temperature data for tank TY-103 starts in 1977 (Flanagan 1994). The current temperature data show that tank TY-103 has had a consistently low waste temperature (65 to $70^{\circ} \mathrm{F}$ ), with no cooling trends that would indicate higher waste temperatures just prior to 1977.

As indicated in Table C-4, from 1953 to 1954 , tank TY-103 received uranium recovery waste, and waste was transferred to tank TY-104 through the cascade plumbing. In the fourth quarter of 1954 , tank TY-103 was nearly emptied when approximately $625 \mathrm{kgal}$ of its waste was transferred to tank TX-111. Because the uranium recovery waste did not contain a high fission product inventory, the temperature of the tank waste was not very high during this time period.

From 1954 to 1956 , tank TY-103 received first-cycle ferrocyanide waste with the liquid periodically being decanted to a crib. The fission product inventory of these TBP wastes were not high so the tank temperature was not high during this time period.

From 1957 to 1959 , the tank level was nearly static, with no significant transfers (a small amount of water was transferred to tank TY-103). In 1959, tank TY-103 received a transfer of about $220 \mathrm{kgal}$ from tank TY-106. The waste from tank TY-106 was supernatant from TBP, or uranium recovery waste that did not have a high fission product inventory and would not have significantly raised TY-103 waste temperature.

In 1961 , about $230 \mathrm{kgal}$ of waste was transferred from tank TX-118 to tank TY-103, raising its level from $510 \mathrm{kgal}$ to $741 \mathrm{kgal}$, nearly filling the tank to its $750-\mathrm{kgal}$ capacity $(2: 5$ dilution factor). Prior to this time (since 1958), tank TX-118 had been receiving periodic transfers from 221-U (U Plant) consisting of evaporator bottoms and TBP wastes. The evaporator bottoms would have been thermally hot, and the transfer to tank TY-103 from TX-118 was probably waste at an elevated $\left(180\right.$ to $\left.200^{\circ} \mathrm{F}\right)$ temperature. However, the dilution in tank TY-103 (2:5) would have lowered the temperature in TY-103. 
Table C-4. TY-103 Transfers Inficating Pre-1971 Waste Temperature History ${ }^{\star}$

\begin{tabular}{|c|c|}
\hline Horicharter & 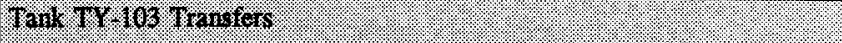 \\
\hline $1953-3$ & Uranium recover wastes, cascaded to TY-104 \\
\hline $1953-4$ & TY-103 level at $758^{b}$ \\
\hline $1954-4$ & $-627^{b}$ to $\mathrm{TX}-111$ \\
\hline $1955-1956$ & First cycle ferrocyanide seavenged wastes \\
\hline $1959-4$ & 207 from TY-106 (TBP waste) \\
\hline $1961-3$ & 231 from TX-118 \\
\hline $1967-3,4$ & \\
\hline $1968-1$ & 546 from $\mathrm{AX}-102,-546$ to $\mathrm{TX}-118$ \\
\hline $1968-2$ & -540 to $\mathrm{TX}-118$ \\
\hline $1968-3$ & 1075 from BX-102 and BX-103, -762 to TX-118 \\
\hline $1968-4$ & 481 from $\mathrm{BX}-103,-371$ to $\mathrm{TX}-118$ \\
\hline 1969-1 & 413 from BX-103, -843 to $\mathrm{TX}-118$ \\
\hline $1969-2$ & 465 from T-103, 448 from T-112, -741 to TX-118 \\
\hline $1969-3$ & 945 from $\mathrm{T}-103,48$ from $\mathrm{T}-104,463$ from $\mathrm{T}-106,-1,314$ to $\mathrm{TX}-118$ \\
\hline $1969-4$ & 275 from T-107, 415 from T-109, -653 to TX-118 \\
\hline 1970-1 & 418 from $\mathrm{U}-112,-333$ to $\mathrm{TY}-104,-207$ to TX-118 \\
\hline $1970-2$ & 474 from S-104, -397 to $\mathrm{TX}-118$ \\
\hline $1970-3$ & 246 from S-107, -349 to $\mathrm{TX}-118$ \\
\hline $1970-4$ & 1048 from BX-1026, 382 from $\mathrm{U}-111,-542$ to TY-104, -843 to TX-118, \\
\hline $1971-1$ & 356 from $\mathrm{BX}-106,-94$ to $\mathrm{TX}-118$ \\
\hline $1973-2$ & -202 to $\mathrm{TY}-102$ \\
\hline $1973-3$ & (tank leaks), -227 to TX-104, -78 to TX-118 \\
\hline 1976 & Inactive leaker \\
\hline
\end{tabular}

Note:

"Data from Agnew et.al. (1996).

${ }^{b}$ Gallons x 1000 
From 1961 to 1967 , tank TY-103 was nearly static with no recorded transfers in or out of the tank. The tank waste temperature would have been slowly decreasing during this time period (from an estimated temperature of $140^{\circ} \mathrm{C}$ ) from diluted waste transfers from tank TX-118, although TX-118 did have fairly hot wastes. The high was temperature in tank TX-118 was due to periodic, small transfers from 221-T (T Plant) consisting of evaporator bottoms and tributyl phosphate decontamination waste that started in 1960 and continued until about 1965 , when tank TX-118 began to be used as the feed for the 242-T evaporator.

From 1967 to 1968 , tank TY-103 was part of a waste flow that transferred wastes to tank TX-118 from a number of tanks. Tank TY-103 received wastes from tanks AX-102, BX-103, BX-106, T-103, T-107, and others. Periodic transfers were made from tanks TY-103 to TX-118 during this time period.

The transfer from tank AX-102 may have carried fairly warm materials into tank TY-103 as $\mathrm{AX}-102$ had a waste temperature of 220 to $240^{\circ} \mathrm{F}$. However, the wastes in the transfers from the other tanks were cladding waste and B Plant low-level waste, which were not high-heat-generating wastes. The decay of the fission products in these wastes would not have raised the temperature of tank TY-103 significantly.

The low temperature history for tank TY-103 is also indicated by the lack of a temperature change within tank TY-104 after TY-104 had received a significant transfer from tank TY-103 in the 1969 to 1970 time period. In the first quarter of 1970 , tank TY-104 received a significant transfer ( $333 \mathrm{kgal}$ ) from tank TY-103, which would have raised the temperature in tank TY-104 if the waste from tank TY-103 was very warm. Archived data for TY-104 show a low $\left(70^{\circ} \mathrm{F}\right)$ temperature in 1971 , indicating little or no impact from this transfer.

Waste transfer records indicate that tank TY-103 may have had a moderately high temperature ( $150^{\circ} \mathrm{F}$ and above) as a result of hot transfers from tank $\mathrm{AX}-102$ and some warm waste from tank TX-118. However, all other transfers to tank TY-103 were low fission product wastes that were at low temperatures.

\section{C.5.4 TY-104 Summary of Waste Transfer and Temperature Histories}

Archived temperature data are available for tank TY-104 from 1970 to the present (Flanagan 1994). Since 1970 , tank TY-104 shows a consistently low waste temperature $\left(65\right.$ to $\left.75^{\circ} \mathrm{F}\right)$ with a gradual decline.

Tank TY-104 initially received waste through its cascade connection with tank TY-103 (Agnew et al. 1995a). A number of cascades were received from tank TY-103, while transfers were made to tanks TX-118 and TX-109.

As indicated in Table C-5, in the first quarter of 1955, tank TY-104 received about $700 \mathrm{kgal}$ from tank TY-103; this transfer was the source of ferrocyanide in tank TY-104. In the third quarter of 1955 , about $635 \mathrm{kgal}$ of the decanted waste was transferred to a crib, which nearly emptied the tank. Between 1955 and 1959, the tank level (nearly empty) was static. 
Table C-5. TY-104 Waste Transfers Indicating Pre-1970 Waste Temperature History

\begin{tabular}{|c|c|}
\hline 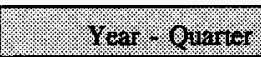 & 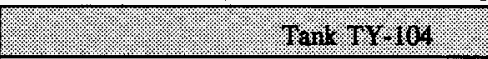 \\
\hline $1953-3$ & $758^{b}$ from $T Y-103$ (cascade) \\
\hline $1953-4$ & -646 to $\mathrm{TX}-118$ \\
\hline $1955-1$ & 700 from TY-103, -709 to TX-109 \\
\hline $1955-3$ & -635 to $\mathrm{crib}$ \\
\hline $1955-1959$ & (Level Static/no transfers) \\
\hline $1959-1961$ & 626 from TX-118 \\
\hline $1961-1966$ & (Level Static/no transfers) \\
\hline $1966-3$ & (TY-104 nearly emptied), -674 to TX-118 \\
\hline 1967 & 658 from TX-115 \\
\hline $1967-1969$ & (Level Static/no transfers) \\
\hline $1970-1$ & 337 from TY-103, -367 to TX-118 \\
\hline $1970-2$ & -498 to TX-118 \\
\hline $1970-4$ & 542 from $T Y-103$ \\
\hline $1970-1973$ & (Level Static/no transfers, Full Tank) \\
\hline $1974-1$ & -678 to $S-110$ \\
\hline 1975 & Removed from service \\
\hline 1978 & Stabilized \\
\hline
\end{tabular}

Note:

'Data from Agnew et.al. (1996).

${ }^{b}$ Gallons x 1000

Between 1959 and 1961, tank TY-104 received about $626 \mathrm{kgal}$ from tank TX-118 of evaporator bottoms and TBP waste. Prior to and during these transfers, tank TX-118 was receiving periodic transfers from $222-\mathrm{U}$ (U Plant) that would have been high-heat-generating waste. The tank (nearly full) was static between the third quarter of 1961 and the second quarter of 1966 (about four years). The temperature in tank TY-104 would have become nearly constant, because the heat from the tank TX-118 waste transfer permeated to ferrocyanide in the tank's lower sludge layers. 
In 1966 , about $674 \mathrm{kgal}$ were transferred to tank TX-118, again nearly emptying the tank. In 1967, tank TY-104 received about $658 \mathrm{kgal}$ from tank TX-115. The waste in tank TX-115 was 242-T evaporator wastes mixed with a recent transfer from tank S-107. Although the evaporator waste probably was very warm, the waste from tank S-107 was also probably very warm, because it contained high-level REDOX wastes directly from the REDOX Plant. From archived transfer data, in 1960 S-107 was boiling and losing liquid through boiling (Agnew et al. 1995b).

Between 1967 and 1969, tank TY-104's level was static, with no recorded activities; this condition would have produced a nearly constant temperature throughout the tank's contents.

In the first quarter of 1970 , about $367 \mathrm{kgal}$ were transferred to tank TX-118, and then about the same volume was transferred from tank TY-103. This TY-103 transfer would have diluted the tank's contents by about a 2:1 ratio, and only a slight change in TY-104's temperature is suspected to have taken place. The 1970 archived data for tank TY-104 shows its waste temperature at about a $70^{\circ} \mathrm{F}$ level. This would indicate that the temperatures of the waste transferred from tank TY-103 and the waste that remained in TY-103 were not high.

In the second quarter of 1970 , a transfer of $498-\mathrm{kgal}$ transfer was made to tank TX-118. In the fourth quarter of 1970, tank TY-104 received another transfer ( $542 \mathrm{kgal}$ ) from tank TY-103. The level in tank TY-104 was static between 1970 and 1973 (tank TY-104 was also full during this time period). The archived data for 1970 show a temperature of about $70^{\circ} \mathrm{F}$ with only a slight downward trend, indicating a cool, near-term temperature history.

In $1974,678 \mathrm{kgal}$ were pumped to tank S-110, and in 1975, tank TY-104 was removed from service, leaving a relatively small sludge level in the tank.

The transfer data indicate that tank TY-104 may have gone through some very short time periods in the 1960s with slightly elevated temperatures. However, archived data and transfer records show tank TY-104 as a tank with relative cold wastes.

\section{C.6 APPENDIX C REFERENCES}

Anderson, J. D., 1990, A History of the 200 Area Tank Farms, WHC-MR-0132, Westinghouse Hanford Company, Richland, Washington.

Agnew, S. F., R. A. Corbin, T. B. Duran, K. A. Jurgensen, T. P. Ortiz, and B. L. Young, 1995a, Waste Status and Transaction Record Summary for the Northwest Quadrant of the Hanford 200 Area, WHC-SD-WM-TI-699, Rev. 1, Los Alamos National Laboratory, Los Alamos, New Mexico. 
Agnew, S. F., R. A. Corbin, T. B. Duran, K. A. Jurgensen, T. P. Ortiz, and B. L. Young, 1995b, Waste Status and Transaction Record Summary for the Southwest Quadrant of the Hanford 200 Area, WHC-SD-WM-TI-614, Rev. 1, Los Alamos National Laboratory, Los Alamos, New Mexico.

Backman, G. E., E. M. Johnston, H. C. Rathvon, L. W. Roddy, and M. F. Wiitala, 1965, Chemical Processing Department Hazards Evaluation In-Tank Waste Solidification Project CAC-965, RL-SEP-65, Hanford Atomic Products Operation, General Electric Company, Richland, Washington.

Barnes, J. W., 1972, Engineering Study of Alternative Tank Farm Cooling Systems, ARH-2405-1, Atlantic Richfield Hanford Company, Richland, Washington.

Borsheim, G. L., and B. C. Simpson, 1991, An Assessment of the Inventories of the Ferrocyanide Watch List Tanks, WHC-SD-WM-ER-133, Rev. 0, Westinghouse Hanford Company, Richland, Washington.

Brevick, C. H., L. A. Gaddis, and A. C. Walsh 1994a, Supporting Document for the North East Quadrant Historical Tank Content Estimate Report for BY-Tank Farm, WHC-SD-WM-ER-312, Rev. 0, ICF Kaiser Hanford Company, Richland, Washington.

Brevick, C. H., L. A. Gaddis, and A. C. Walsh 1994b, Supporting Document for the North East Quadrant Historical Tank Content Estimate Report for C-Tank Farm, WHC-SD-WM-ER-313, Rev. 0, ICF Kaiser Hanford Company, Richland, Washington.

Brevick, C. H., L. A. Gaddis, and W. W. Pickett 1995a, Supporting Document for the Northwest Quadrant Historical Tank Content Estimate Report for TY-Tank Farm, WHC-SD-WM-ER-322, Rev. 0, ICF Kaiser Hanford Company, Richland, Washington.

Brevick, C. H., L. A. Gaddis, and W. W. Pickett 1995b, Supporting Document for the Northwest Quadrant Historical Tank Content Estimate Report for TX-Tank Farm, WHC-SD-WM-ER-321, Rev. 0, ICF Kaiser Hanford Company, Richland, Washington.

Caudill, H. L., 1965, Design Criteria for a Second In-Tank Solidification System, RL-SEP-499, Hanford Atomics Products Operation, General Electric Company, Richland, Washington.

Flanagan, B. D., 1994, Maximum Surface Level and Temperature Histories for Hanford Waste Tanks, WHC-SD-WM-TI-591, Westinghouse Hanford Company, Richland, Washington. 
Godfrey, W. L., and P. W. Smith, 1968, Evolution and Status of In-Tank Solidification, ARH-905, Atlantic Richfield Hanford Company, Richland, Washington.

McKnight, J. P., 1969, Design Criteria Additional ITS-2 Waste Concentrate Facilities 24I-BY Tanks: 103, 104, 105, and 106, ARH-1254, Atlantic Richfield Hanford Company, Richland, Washington.

Mercier, P. F., C. DeFigh-Price, and M. D. Wonacott, 1984, Summary of the Single-Shell Tank Thermal Histories, RHO-CD-1122, Rockwell Hanford Operations, Richland Washington.

Postma, A. K., J. E. Meacham, G. S. Barney, G. L. Borsheim, R. J. Cash, M. D. Crippen, D. R. Dickinson, J. M. Grigsby, D. W. Jeppson, M. Kummerer, J. M. McLaren, C. S. Simmons, and B. C. Simpson, 1994, Ferrocyanide Safety Program: Safety Criteria for Ferrocyanide Watch List Tanks, WHC-EP-0691, Westinghouse Hanford Company, Richland, Washington.

Shefcik, J. J., 1964, Process Specifications for In-Tank Solidification of Radiochemical Wastes, RL-SEP-115, Hanford Atomic Products Operation, General Electric Company, Richland, Washington. 
WHC-SD-WM-SARR-038, Rev. 1

This page intentionally left blank. 
WHC-SD-WM-SARR-038, Rev. 1

\section{APPENDIX D}

FERROCYANIDE AGING EXPERIMENTS

D-1 
WHC-SD-WM-SARR-038, Rev. 1

This page intentionally left blank. 


\section{APPENDIX D}

\section{FERROCYANIDE AGING EXPERIMENTS}

Experiments, theory, and tank sample data indicate that ferrocyanide compounds decompose in time to inert chemicals under chemical and radiological conditions found in the Hanford high-level waste tanks. This process, called ferrocyanide aging, ultimately eliminates the combustion hazard associated with ferrocyanides in the wastes (Babad et al. 1993).

The overall destruction of sodium nickel ferrocyanide, $\mathrm{Na}_{2} \mathrm{NiFe}(\mathrm{CN})_{6}$, can be described by several general equations. Dissolution occurs when the ferrocyanide contacts a caustic solution (Equation D-1). This stoichiometry is consistent with experimental results (Lilga et al. 1996). Hydrolysis, as shown in Equation D-2 for one reported stoichiometry (Robuck and Luthy 1989), converts ferrocyanide to ammonia, formate, and iron oxides and occurs both when the ferrocyanide dissolves or when it remains insoluble. Equation D-3 has also been shown in these studies to be important in the hydrolysis of sodium nickel ferrocyanide.

$$
\begin{gathered}
\mathrm{Na}_{2} \mathrm{NiFe}(\mathrm{CN})_{6}(\mathrm{~s})+2 \mathrm{NaOH}=\mathrm{Na}_{4} \mathrm{Fe}(\mathrm{CN})_{6}+\mathrm{Ni}(\mathrm{OH})_{2}(\mathrm{~s}) \\
6 \mathrm{Fe}\left(\mathrm{CN}_{6}^{-4}+12 \mathrm{OH}^{-}+66 \mathrm{H}_{2} \mathrm{O}+\mathrm{O}_{2}=36 \mathrm{HCO}_{2}^{-}+2 \mathrm{Fe}_{3} \mathrm{O}_{4}+36 \mathrm{NH}_{3}\right. \\
\mathrm{Ni}(\mathrm{CN})_{4}^{-2}+2 \mathrm{OH}^{-}+8 \mathrm{H}_{2} \mathrm{O}=4 \mathrm{HCO}_{2}^{-}+\mathrm{Ni}(\mathrm{OH})_{2}+4 \mathrm{NH}_{3}
\end{gathered}
$$

Equations D-2 and D-3 assume that all cyanide carbon is converted to formate and all cyanide nitrogen is converted to ammonia. Depending on the mechanism of hydrolysis, ferrocyanide aging could involve cyanide or cyanate intermediates. The stoichiometry shown in Equations D-2 and D-3 is not necessarily what is experimentally observed, because radiolysis further decomposes ammonia and formate. However, good material balances were obtained in experiments where the mass of ammonia produced was compared to the mass of cyanide destroyed (Lilga et al. 1996). Mass balances for these experiments are shown in Table D-1. 
Table D-1. Mass Balances for Cyanide and Ammonia in Ferrocyanide Aging Experiments.

\begin{tabular}{|c|c|c|c|c|c|}
\hline 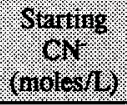 & (molestit) & 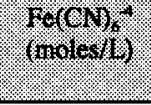 & $\begin{array}{l}\text { nugri, } \\
\text { molest) }\end{array}$ & 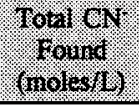 & $\begin{array}{l}\text { Material } \\
\text { Balance } \\
(\%)\end{array}$ \\
\hline 0.0996 & 0.0150 & 0.0154 & 0.0 & 0.1074 & 108 \\
\hline 0.0996 & 0.0410 & 0.0385 & 0.00850 & 0.0981 & 99 \\
\hline 0.0996 & 0.0684 & 0.0104 & 0.0212 & 0.1000 & 100 \\
\hline 0.0996 & 0.0110 & 0.0160 & 0.0 & 0.1070 & 107 \\
\hline 0.0996 & 0.0383 & 0.00605 & 0.00806 & 0.1068 & 107 \\
\hline 0.0996 & 0.00910 & 0.0165 & 0.0 & 0.1081 & 109 \\
\hline 0.0996 & 0.0152 & 0.0132 & 0.00210 & 0.1028 & 103 \\
\hline 0.0960 & 0.00087 & 0.0155 & 0.0 & 0.0939 & 98 \\
\hline 0.0960 & 0.0205 & 0.00390 & 0.00970 & 0.0827 & 86 \\
\hline 0.1032 & 0.0413 & 0.0114 & 0.0 & 0.1097 & 106 \\
\hline 0.1032 & 0.0375 & 0.00557 & 0.00716 & 0.0995 & 96 \\
\hline
\end{tabular}

Atomic absorption (AA) analyses of reaction solutions showed that both soluble iron and nickel species were present. Fourier transform infrared spectroscopy (FTIR) was used to identify the soluble iron as $\mathrm{Fe}(\mathrm{CN})_{6}{ }^{-4}$ and soluble nickel as $\mathrm{Ni}(\mathrm{CN})_{4}^{-2}$. Concentrations determined by FTIR were nearly identical to the concentrations from AA, showing that essentially all of the soluble iron and nickel were present as the cyano complexes. Quantitation of these cyano species allowed a determination of the approximate cyanide balance. The total cyanide found is the sum of the moles of ammonia, moles of cyanide as ferrocyanide (six times the value shown in column three), and moles of cyanide as nickel cyanide (four times the value shown in column four). A comparison of the total cyanide found to the starting cyanide yielded material balances ranging from 89 to $109 \%$. The amount of ammonia destroyed by radiolysis is not included in these calculations. The good mass balance shows that ammonia is an appropriate indicator of the extent of aging.

The available literature (MacDiarmid and Hall 1953, Masri and Haissinsky 1963, Hughes and Willis 1961, Ohno and Tsuchihasi 1965, Robuck and Luthy 1979) indicate that three main parameters can affect the rate of aging: exposure to high $\mathrm{pH}$ solutions, radiation dose rate, and temperature. Experiments were conducted to determine how the rate of ferrocyanide decomposition is affected by $\mathrm{pH}$, dose rate, and temperature. Understanding how these parameters affect ferrocyanide aging allows extrapolation of data from sampled tanks to unsampled tanks. 


\section{D.1 WASTE pH}

Although the precipitation of sodium nickel ferrocyanide was done at slightly alkaline conditions $(\mathrm{pH}=8.0-10)$, the ferrocyanide tanks were used for a variety of waste management operations that exposed the tanks to alkaline waste (Anderson 1990) of high $\mathrm{pH}$ values. Table D-2 presents a summary of the available historical $\mathrm{pH}$ and hydroxide data collected for the eighteen ferrocyanide tanks (Wodrich et al. 1992).

Values for $\mathrm{pH}$ presented in Table D-2 are only estimates, because of the solutions tested had a high ionic strength (most of the samples exceeded $4.0 \mathrm{~N}$ making a direct correlation between hydrogen ion activity and concentration difficult). Therefore, the hydroxide concentration measurements presented are a more reliable measure of basicity. Hydroxide concentrations were measured by direct potentiometric titration of the solutions with a standardized acid.

Except for tank BY-111 (which had no data later than June 1956), historical pH and hydroxide data show that all the ferrocyanide tanks have contained enough caustic to promote aging (i.e., had $\mathrm{pH}$ values higher than 10) since the ferrocyanide scavenging campaigns were completed. Tank BY-111 was used for the same operations that transferred high pH waste into the other BY farm ferrocyanide tanks. Consequently, waste $\mathrm{pH}$ was not a limiting factor for ferrocyanide waste aging in Hanford Site tanks.

\section{D.2 RADIATION DOSE RATE}

Experiments to investigate the influence of incident gamma dose rate on the rate of hydrolysis of In-Farm ferrocyanide simulant were conducted at $90^{\circ} \mathrm{C}$ in $2 \mathrm{M} \mathrm{NaOH}$ solutions. Figure D-1 shows the production of ammonia as a function of time in experiments conducted with applied dose rates between $10^{4}$ to $10^{5} \mathrm{rad} / \mathrm{h}$. Ammonia production was approximately linear with exposure time, and the rate constants at each applied dose rate were estimated from the slopes of the plots.

Figure D-2 shows the Eyring relationships for available data with no applied gamma radiation and at applied gamma dose rates up to $1 \times 10^{5} \mathrm{rad} / \mathrm{h}$. The Eyring plots at the various dose rates again show nearly parallel lines; i.e., the activation energy is independent of dose rate. This suggests that radiation dose has only a limited affect on reaction rate.

The results of these experiments are revealing in that the rate of aging is only noticeably affected at high dose rate $\left(10^{4}\right.$ to $\left.10^{5} \mathrm{Rad} / \mathrm{h}\right)$. There was little impact from dose rate observed for dose rates between 0 and $1000 \mathrm{Rad} / \mathrm{h}$, and the estimated rate of ferrocyanide decomposition is similar. The dose rate in the ferrocyanide waste tanks was in the $1,000 \mathrm{Rad} / \mathrm{h}$ range, and no ferrocyanide tanks had dose rates approaching $10,000 \mathrm{Rad} / \mathrm{h}$ (Parra 1996). Consequently, dose rates in the ferrocyanide tanks had only a second order effect on the rate of aging. 


\begin{tabular}{|c|c|c|c|c|c|c|c|}
\hline $\begin{array}{l}\text { ZL/ZO } \\
\text { S9/EO }\end{array}$ & $\tau \varepsilon \cdot 0$ & $\begin{array}{l}I^{\prime} Z I \\
0^{\circ} Z I\end{array}$ & t0I- $X \perp$ & $\begin{array}{l}9 L / 90 \\
Z L / I 0\end{array}$ & $\begin{array}{l}\tau \cdot \varepsilon \\
9^{\prime} 9\end{array}$ & $\begin{array}{l}t I< \\
t I<\end{array}$ & $\tau \mathrm{II}-\lambda \mathrm{g}$ \\
\hline $\begin{array}{l}\text { ZL/Z0 } \\
\text { S9/E0 } \\
\text { SS/90 }\end{array}$ & 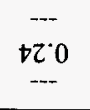 & $\begin{array}{l}L^{\circ} I I \\
0^{\circ} \mathrm{ZI} \\
L^{\circ} 6\end{array}$ & $\varepsilon 0[-X . L$ & $9 S / 90$ & -- & 9.6 & I I I-Xg \\
\hline $\begin{array}{l}Z 8 / Z \mathrm{I} \\
\$ 9 / \varepsilon 0 \\
9 S / \mathrm{II}\end{array}$ & $\begin{array}{c}S 0^{\circ} 0 \\
\mathcal{E} 0^{\circ} 0 \\
---\end{array}$ & $\begin{array}{l}L \cdot 2 \mathrm{I} \\
\text { S'ZI } \\
1 \cdot 6\end{array}$ & $\mathrm{I}^{\prime} \mathrm{I}^{-} \boldsymbol{\lambda} \mathrm{J}$ & $\begin{array}{l}9 L / 90 \\
L S / 90 \\
t S / 0 I\end{array}$ & $\begin{array}{l}\text { I' } \mathcal{E} \\
--- \\
---\end{array}$ & $\begin{array}{l}\quad t I< \\
6 . I I \\
8.6\end{array}$ & $0 I I-x \mathbf{g}$ \\
\hline $\begin{array}{l}\text { 08/I0 } \\
Z L / \varsigma 0 \\
\text { S9/E0 }\end{array}$ & $\begin{array}{l}\tau \cdot \varepsilon \\
0^{\circ} \varepsilon \\
9 \cdot 0\end{array}$ & $\begin{array}{c}t I< \\
t I< \\
8 . \varepsilon I\end{array}$ & $8 \mathrm{II}-\mathrm{XJ}$ & $\begin{array}{l}\mathrm{I} 6 / 90 \\
06 / \mathrm{II} \\
t \mathrm{~S} / \mathrm{II}\end{array}$ & $\begin{array}{l}t^{\circ} z \\
s^{\prime} z \\
--\end{array}$ & $\begin{array}{l}t^{*} \varepsilon I \\
\tau \cdot \varepsilon I \\
0.6\end{array}$ & $80 I-x 8$ \\
\hline $\begin{array}{l}68 / 60 \\
S L / 60 \\
S 9 / \varepsilon 0\end{array}$ & $\begin{array}{c}\mathcal{E} 0^{\circ} 0 \\
\mathrm{I}^{\circ} 0 \\
\tau^{\circ} 0\end{array}$ & $\begin{array}{l}I \cdot I I \\
\varepsilon \cdot Z I \\
\tau \cdot \varepsilon I\end{array}$ & $\angle O I-I$ & $\begin{array}{l}6 L / L 0 \\
L S / t 0 \\
t S / L I\end{array}$ & $\begin{array}{l}z \cdot s \\
---\end{array}$ & $\begin{array}{l}\quad t I< \\
\varepsilon \cdot \tau I \\
\varepsilon \cdot 6\end{array}$ & $\angle 0 I-X g$ \\
\hline $\begin{array}{l}S L / 90 \\
L L / Z I \\
9 S / I 0\end{array}$ & $\begin{array}{l}\varsigma_{0} 0 \\
--- \\
--\end{array}$ & $\begin{array}{l}6 . \mathrm{II} \\
L^{\circ} \mathrm{II} \\
\text { I.0I }\end{array}$ & ZI [-O & $\begin{array}{l}06 / I I \\
Z L / \text { t0 } \\
\text { SS/EO }\end{array}$ & $\begin{array}{l}6.2 \\
6 . \varepsilon \\
--\end{array}$ & $\begin{array}{c}s \cdot \varepsilon I \\
\forall I< \\
\downarrow * 6\end{array}$ & $90 \tau-\lambda g$ \\
\hline $\begin{array}{l}\text { SL/ZO } \\
\angle S / 0 I \\
\text { SS/SO }\end{array}$ & $\begin{array}{c}8^{\circ} 0 \\
--- \\
--\end{array}$ & $\begin{array}{l}6 \cdot \varepsilon I \\
9 \cdot 8 \\
\tau \cdot 21\end{array}$ & II I-D & $\begin{array}{l}I 6 / 90 \\
06 / I I \\
9 S / L 0\end{array}$ & $\begin{array}{l}8 \cdot 0 \\
8 \cdot 0 \\
--\end{array}$ & $\begin{array}{l}\varepsilon^{*} \varepsilon I \\
\tau^{\prime} \varepsilon I \\
\varepsilon^{\prime} 6\end{array}$ & $\varsigma_{0}[-\lambda g$ \\
\hline $\begin{array}{l}06 / \mathrm{II} \\
\text { SL/90 } \\
\text { IL/ZI }\end{array}$ & $\begin{array}{l}S^{\circ} 0 \\
8.0 \\
---\end{array}$ & $\begin{array}{l}L^{\circ} \varepsilon I \\
S^{\circ} Z I \\
6^{\circ} I I\end{array}$ & $60[-5$ & $\begin{array}{l}\text { 9L/EO } \\
\text { SS/II }\end{array}$ & $\stackrel{L \cdot \varepsilon}{\angle \cdot \varepsilon}$ & $\begin{array}{c}\forall I< \\
\varepsilon^{\circ} 6\end{array}$ & $t 0 I-x g$ \\
\hline $\begin{array}{l}S L / 60 \\
I L / Z I \\
9 \varsigma / \varsigma 0\end{array}$ & $\begin{array}{l}\text { So } \\
-- \\
--\end{array}$ & $\begin{array}{l}8.11 \\
8.11 \\
8.6\end{array}$ & $80[-5$ & $\begin{array}{l}\mathrm{I} 6 / 90 \\
06 / 1 \mathrm{I} \\
\text { SS/SO }\end{array}$ & $\begin{array}{l}9 \cdot z \\
9.7 \\
--\end{array}$ & $\begin{array}{l}\varsigma \varepsilon I \\
\varepsilon \cdot \varepsilon I \\
\varepsilon \cdot \sigma\end{array}$ & $\mathcal{E} 0 \mathrm{I}-\lambda \mathrm{g}$ \\
\hline 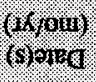 & 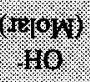 & $n^{1 d}$ & शine & Giour & $\begin{array}{l}10 \% \\
110\end{array}$ & $7^{1}$ & intol \\
\hline
\end{tabular}

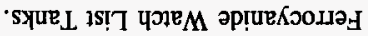

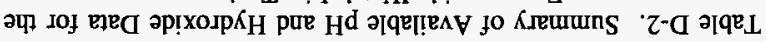


Figure D-1. Ammonia Product as a Function of Time for Various Gamma Dose Rates.

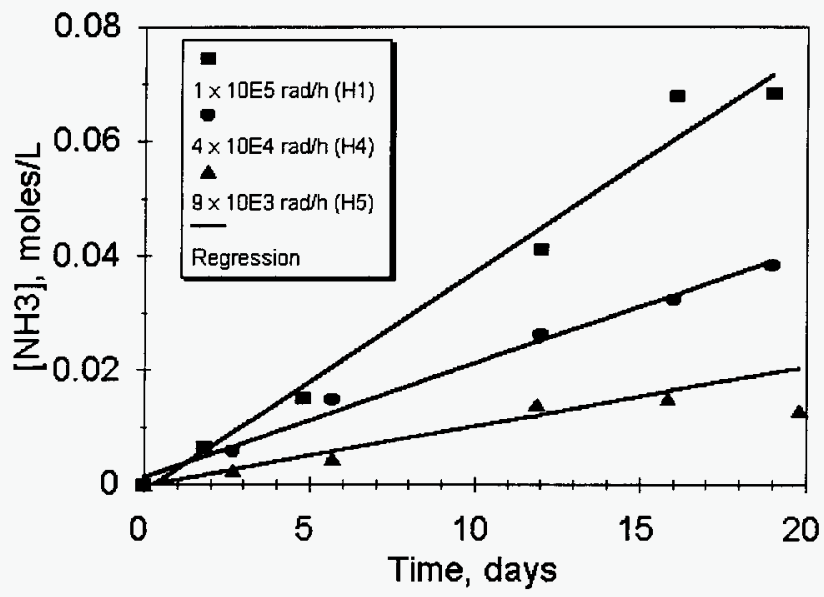

Figure D-2. Eyring Plot for Ammonia Production at Various Dose Rates.

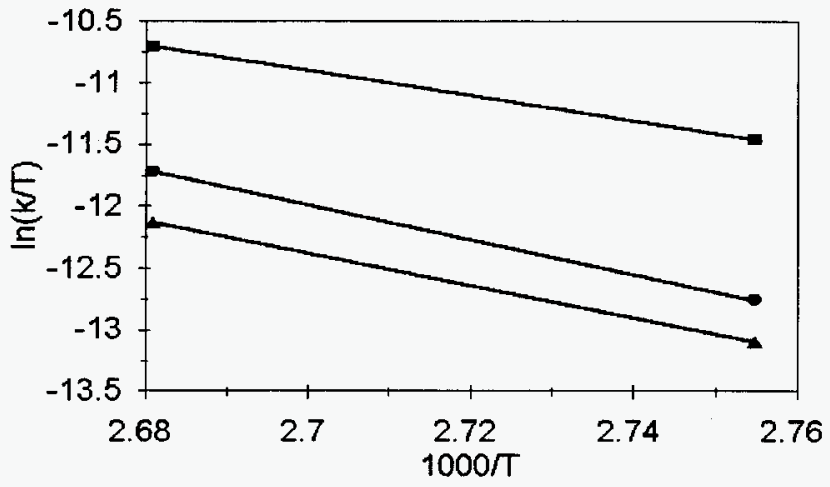

$\rightarrow-1 \times 10 E 5 \mathrm{Rad} / \mathrm{h} \rightarrow 1 \times 10 \mathrm{E} 4 \mathrm{Rad} h \quad$ No Gamma

D-7 


\section{D.3 TEMPERATURE}

Experiments investigating the hydrolysis of ferrocyanide waste simulant in $2 \mathrm{M}$ sodium hydroxide solutions were conducted at $50,70,80,90$, and $100^{\circ} \mathrm{C}$. Ferrocyanide waste simulants were exposed to ${ }^{60} \mathrm{Co}$ gamma radiation at dose rates ranging from about $10^{4}$ to $10^{5} \mathrm{rad}$ per hour ( $\left.\mathrm{rad} / \mathrm{h}\right)$. Experiments were conducted by charging individual vessels with reagents, brought to the same reaction conditions, and withdrawn individually from the gamma pit at various times over a three-week period. Control solutions were not irradiated, but were otherwise prepared and treated identically. The concentrations of ammonia, formate ion, and other aging byproducts were measured. In some cases, the ferrocyanide concentration was measured both in solution and in the insoluble solids.

Results from these experiments show that the rate of ferrocyanide decomposition is a strong function of temperature. Figure D-3 shows the temperature dependence of ammonia production (an indirect measure of the rate of ferrocyanide aging) for the aging experiments. These experiments show that the extent of ferrocyanide aging in Hanford tanks was primarily determined by the individual tank temperature histories.

Figure D-3. Ammonia Production as a Function of Time for Temperatures of $50,70,80,90$, and $100^{\circ} \mathrm{C}$.

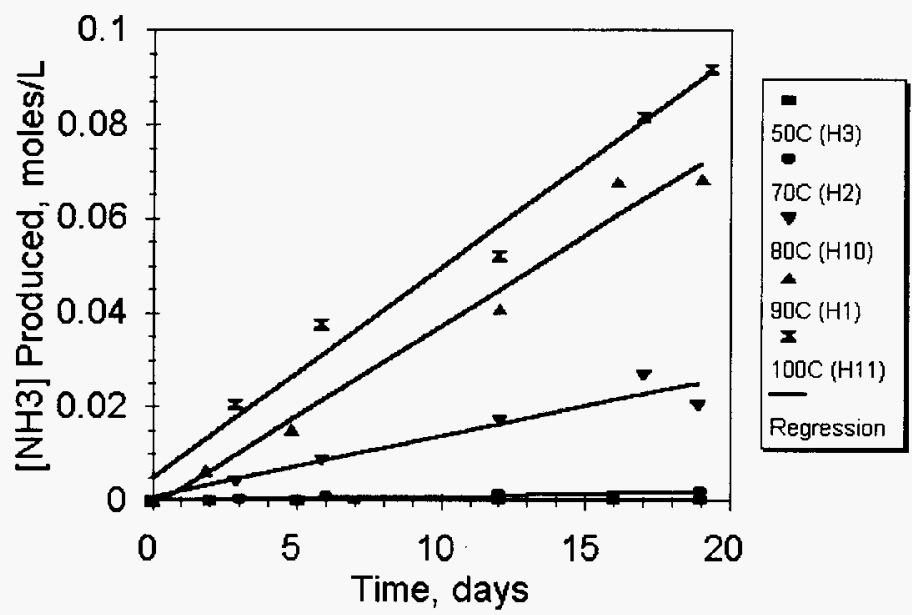




\section{D.4 OVERALL RATE EXPRESSION FOR THE SIMULANT EXPERIMENTS}

Equations (D-2) and (D-3) are global descriptions of processes that occur during aging, but the detailed chemistry is certain to be a much more complicated, multi-step mechanism. Whatever the detailed mechanism may be, the generation of ammonia is one of the key indicators of how much of the $\mathrm{Na}_{2} \mathrm{NiFe}(\mathrm{CN})_{6}$ has been destroyed. The ammonia generation rate for the experimental conditions examined was a zero-order chemical reaction, meaning the rate of disappearance of $\mathrm{Fe}(\mathrm{CN})_{6}^{-4}$ (measured as ammonia production) was independent of the initial and the remaining concentration of $\mathrm{Fe}(\mathrm{CN})_{6}^{-4}$. Zero-order kinetics were chosen to model the rate of ferrocyanide aging, and the rate expression for a zero-order process is shown in Equation (D-4).

$$
-\frac{\mathbf{d C}_{\mathrm{A}}}{\mathbf{d t}}=\mathbf{k}_{\gamma, \mathrm{T}}
$$

Where the actual concentration, $\mathrm{C}_{\mathrm{A}}$, is expressed as g-moles $\mathrm{Fe}(\mathrm{CN})_{6}^{-4} / \mathrm{g}$ dry sludge and the rate constant, $\mathrm{k}_{\gamma, \mathrm{T}}$, is in $\mathrm{g}$-moles $\mathrm{Fe}(\mathrm{CN})_{6}^{-4} / \mathrm{g}$ dry sludge/year. Figure $\mathrm{D}-4$ shows rate constants for the simulant experiments at different temperatures and gamma dose rates.

Figure D-4. Rate Constants (k) versus Temperature at Various Gamma Dose Rates.

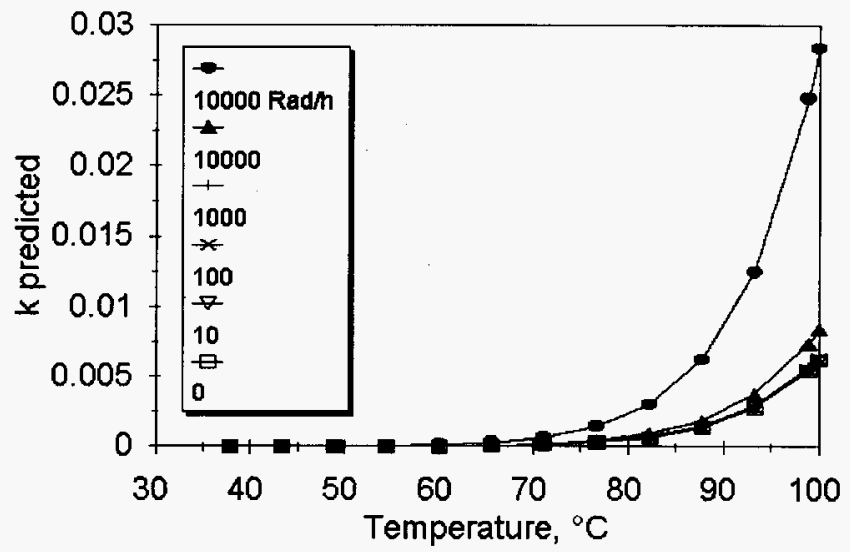


The impact of these experiments is significant in that it allows a method for selecting those tanks that bound ferrocyanide aging. Those tanks with lowest temperature histories would have the least amount of aging. Therefore, sampling data from the coolest ferrocyanide tanks can be extrapolated to those tanks that have not been sampled to make conclusions on the extent of aging for all ferrocyanide tanks.

\section{REFERENCES}

Hughes, G., and C. Willis, 1961, The Radiolysis of Ferro- and Ferri-cyanide Solutions, Department of Inorganic, Physical and Industrial Chemistry, Liverpool University, Great Britain.

Lilga, M. A., E. V. Alderson, R. T. Hallen, M. O. Hogan, T. L. Hubler, G. L. Jones, D. J. Kowalski, M. R. Lumetta, and M. R. Telander, 1996, Ferrocyanide Safety Project: Ferrocyanide Aging Studies - Final Report, PNL-11211, Pacific Northwest Laboratory, Richland, Washington.

MacDiarmid, A. G., and N. F. Hall, 1953, "Illumination-pH Effects in Solutions of Complex Cyanides," Journal of the American Chemical Society, vol. 75, pp. 5204-5207.

Masri, E., and M. Haissinsky, 1963, "Radiolytic Transformations. Gamma-Radiolysis of Potassium Ferro- and Ferricyanide Solutions, " Journal of Chemistry \& Physics, vol. 60 , pp. 397-401.

Ohno, S., and E. Tsuchihasi, 1965, "The Photochemistry of Hexacyanoferrate(II) Ions in Aqueous Solutions," Bulletin of the Chemical Society, vol. 38, Japan, pp. 1052-1053.

Parra, S. A., 1994, Integrated Beta and Gamma Radiation Dose Calculations for Ferrocyanide Waste Tanks, WHC-SD-WM-TI-634, Rev. 0, Westinghouse Hanford Company, Richland, Washington.

Robuck, S. J., and R. G. Luthy, 1989, "Destruction of Iron-Complexed Cyanide by Alkaline Hydrolysis." Water Science Technology vol. 21, pp. 547-558.

Wodrich, D. D., G. S. Barney, G. L. Borsheim, D. L. Becker, W. C. Carlos, M. J. Klem, R. E. Van der Cook, and J. L. Ryan, 1992, Summary of Single-Shell Waste Tank Stability, WHC-EP-0347, Supplement, Westinghouse Hanford Company, Richland, Washington. 


\section{DISTRIBUTION}

Number of copies

\section{OFFSITE}

6

U.S. Department of Energy

EM-38, Trevion II

12800 Middlebrook Road

Germantown, MD 20874

Harry Calley (4)

Maureen Hunemuller

Ken Lang

U.S. Department of Energy

Forrestal Building

1000 Independence Avenue SW

Washington, DC 20585

Shirley Campbell, EH-71

John Kaysak, EM-25

1

Charles S. Abrams

1987 Virginia

Idaho Falls, ID 83404

1

David O. Campbell

102 Windham Road

Oak Ridge, TN 37830

1

Fred N. Carlson

6965 North 5th West

Idaho Falls, ID 83401

1

Billy C. Hudson

202 Northridge Court

Lindsborg, KA 67456

1

Thomas S. Kress

102-B Newridge Road

Oak Ridge, TN 37839 


\section{DISTRIBUTION (Continued)}

Number of copies

\section{OFFSITE}

1

Thomas E. Larson

2711 Walnut Street

Los Alamos, NM 87544

1

Air Products \& Chemicals. Inc. 7201 Hamilton Blvd

Allentown, PA 18195-1501

George E. Schmauch

1

Brookhaven National Laboratory

Upton, NY 11973

Kamal K. Bandyopadhyay

2

Fauske and Associates. Inc, 16 W070 W. 83rd St.

Burr Ridge, IL 60521

Michael Epstein

Hans K. Fauske

1

G \& P Consulting. Inc.

3640 Ballard Road

Dallas, OR 97338

Arlin K. Postma

Harvard University

295 Upland Avenue

Newton Highlands, MA 02161

Melvin W. First 


\section{DISTRIBUTION (Continued)}

Number of copies

OFFSITE

1

Los Alamos National Laboratory

P.O. Box 1663

Los Alamos, NM 87545

Steve F. Agnew

1

MIT/Department of Nuclear Engineering

77 Massachusetts Ave.

Room 24-102

Cambridge, MA 02139

Mujid S. Kazimi

1

Nuclear Consulting Services. Inc.

P.O. Box 29151

Columbus, OH 43229-0151

J. Louis Kovach

Oak Ridge National Laboratory

$1 \quad$ Emory D. Collins

P.O. Box 2008

7930, MS-6385

Oak Ridge, TN 37831-6385

1 Charles W, Forsberg

P.O. Box 2008

MS-6495

Oak Ridge, TN 37831-6495

1

Rice University

5211 Paisley

Houston, TX 77096

Andrew S. Veletsos 


\section{DISTRIBUTION (Continued)}

Number of copies

\section{OFFSITE}

2

Sandia National Laboratories

P.O. Box 5800

Albuquerque, NM 87185

Dana A. Powers, MS-0744

Scott E. Slezak, MS-0741

3

Science Applications International Corporation

20300 Century Blvd, Suite 200-B

Germantown, MD 20874

Paul Hogroian (3)

State of Washington - Department of Ecology

$1 \quad$ Robert C. King

P. O. Box 47600

Olympia, WA $98504-7600$

1

Alex B. Stone

1315 W. 4th Avenue

Kennewick, WA 99336

1

Waste Policy Institute

555 Quince Orchard Road, Suite 600

Gaitherburg, MD 20878-1437

Donald T. Oakley

\section{ONSITE}

10

\section{U.S. Department of Energy. \\ $\underline{\text { Richland Operations Office }}$}

R. G. Harwood

S7-54

W. F. Hendrickson (2)

S7-54

M. F. Jarvis

S7-54 


\section{DISTRIBUTION (Continued)}

A. G. Krasopoulos

A4-81

J. K. McClusky

S7-53

J. C. Peschong

S7-53

Public Reading Room

H2-53

RL Docket File (2)

B1-17

Pacific Northwest Laboratory

J. W. Brothers

K5-22

R. T. Hallen

P8-38

M. A. Lilga

P8-38

Hanford Technical Library

P8-55

Westinghouse Hanford Company

H. Babad

S7-14

M. V. Berriochoa

B3-30

J. B. Billetdeaux

S7-15

W. S. Callaway

S3-90

R. J. Cash (5)

S7-14

M. D. Crippen

L5-31

R. D. Crowe

Ho-32

M. L. Dexter

R1-51

D. R. Dickinson

L5-31

G. T. Dukelow

S7-14

J. M. Grigsby

A3-37

M. N. Islam

R3-08

D. W. Jeppson

L5-31

N. W. Kirch

R2-11

C. A. Kuhlman

B3-30

L. L. Lockrem

S3-90

J. E. Meacham (2)

S7-14

N. J. Milliken

A3-37

S. R. Moreno

B3-06

F. R. Reich

L5-55

E. F. Riedel

S3-90

B. C. Simpson

R2-12

Central Files

A3-88

Correspondence Processing

A3-01

EDMC

H6-08

DPC

A3-94 
WHC-SD-WM-SARR-038, Rev. 1

This page intentionally left blank.

Distr-6 


\section{Assessment of the Potential for Ferrocyanide Propagating Reaction Accidents}

Prepared for the U.S. Department of Energy Assistant Secretary for Environmental Management

(2) Westinghouse
Hanford Company Richland, Washington

Management and Operations Contractor for the

U.S. Department of Energy under Contract DE-AC06-87RL10930

Approved for public release; distribution is unlimited 
LECAL DISCLAMER

This roport was propared as an occount of work sponsored by an agency of the United States Government. Neither the United States Government nor any egency thereof, nor any of their employees, nor any of their contrectors, subcontractors or their employees, makes any warranty, express or implied, or assumes any legal liability or responsibility for the accuracy, completeness, or any third party's use or the results of auch uee of any information, apparatus, product, or process disclosed, or represents thet its use would not infringe privately owned rights. Reference herein to any epecific commerciel product, process, or senvice by trede name, tredemark, manufacturer, or otherwise, does not necesserily constitute or imply its endorsement, recommendetion, or favoring by the United States Government or any egency thereof or its contractors or subcontractors. The views and opinions of authors expressed horein do not necessarily state or reflect thoee of the United States Government or any agency thereof.

This report has been reproduced from the best available copy. Available in paper copy and microfiche.

Available to the U.S. Department of Energy and its contrectors from

U.S. Department of Eneroy

Office of Scientific and Technical Information (OST))

P.O. Box 62

Oak Ridge, TN 37831

(615) $576-8401$

Available to the public from the U.S. Department of Commerce National Technical Information Service (NTIS)

5285 Port Royal Road

Springtield, VA 22161

(703) 487-4650

Printed in the United Stetes of Amence

DISCLM-1.CHP (8-95) 